Supporting Information

\title{
Synthesis of Thio-lignane Analogues, Bioequivalent Salvinal without Unfavored Aldehyde
}

Yohei Saito, ${ }^{\dagger}$ Yukiko Kobayashi, ${ }^{\dagger}$ Nanami Yoshida, ${ }^{\dagger}$ Masuo Goto ${ }^{\ddagger}$ and Kyoko Nakagawa-Goto ${ }^{\dagger,}$ :,*

†School of Pharmaceutical Sciences, College of Medical, Pharmaceutical and Health

Science, Kanazawa University, Kanazawa, 920-1192, Japan

${ }^{\ddagger}$ Chemical Biology and Medicinal Chemistry, UNC Eshelman School of Pharmacy, University of North Carolina at Chapel Hill, Chapel Hill, North Carolina 27599-7568, United States

*Corresponding Author

Kyoko Nakagawa-Goto

School of Pharmaceutical Sciences, College of Medical, Pharmaceutical and Health Sciences, Kanazawa University, Kanazawa, 920-1192. Japan

Email:kngoto@p.kanazawa-u.ac.jp.

Table of contents

Figure S1-S76 ${ }^{1} \mathrm{H}$ NMR and ${ }^{13} \mathrm{C}$ NMR spectra of novel compounds. S2-S39 
Figure S1. ${ }^{1} \mathrm{H}$ NMR spectrum of compound $4\left(400 \mathrm{MHz}\right.$, in $\left.\mathrm{CDCl}_{3}\right)$

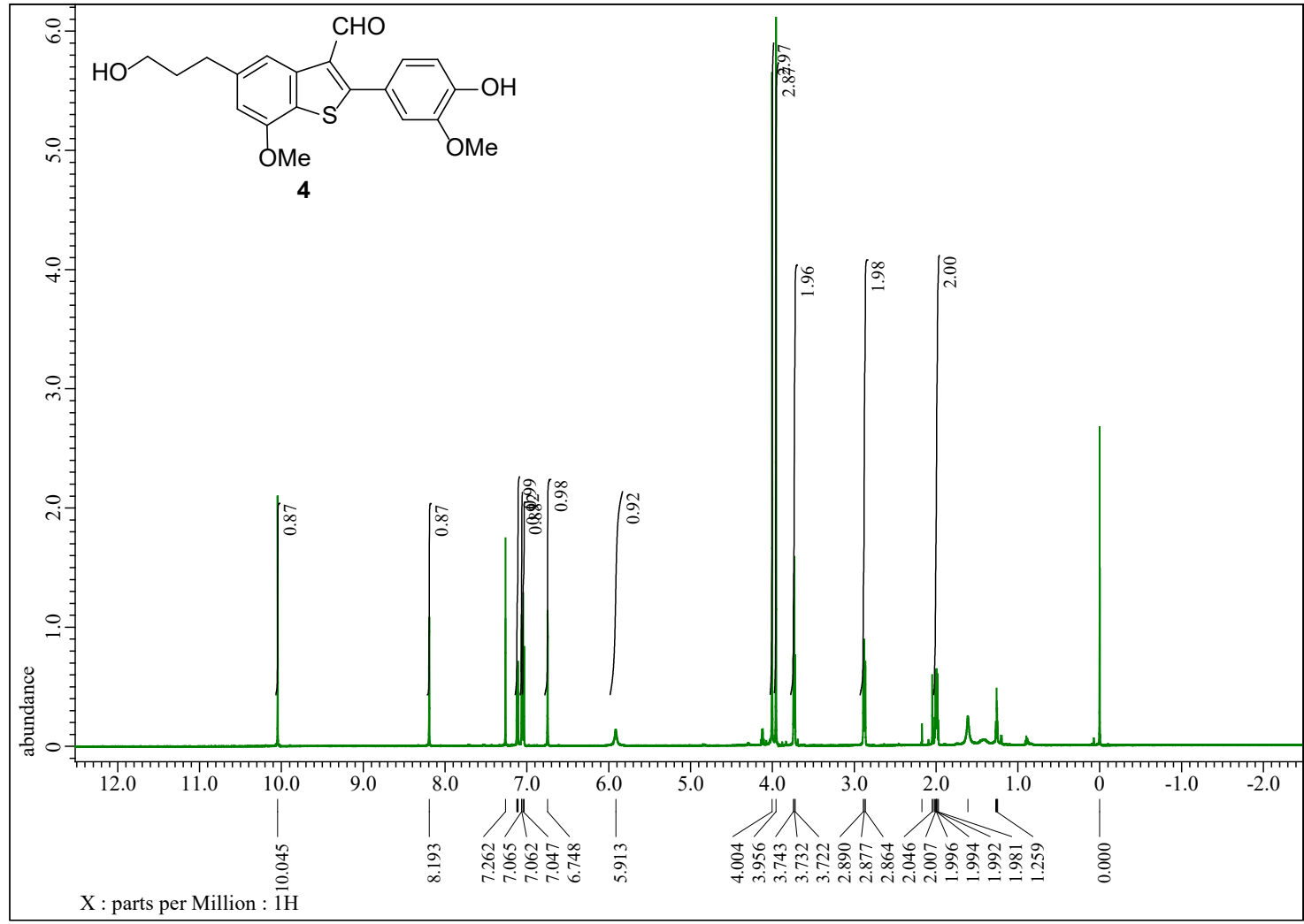

Figure S2. ${ }^{13} \mathrm{C}\left\{{ }^{1} \mathrm{H}\right\}$ NMR spectrum of compound $4\left(150 \mathrm{MHz}\right.$, in $\left.\mathrm{CDCl}_{3}\right)$

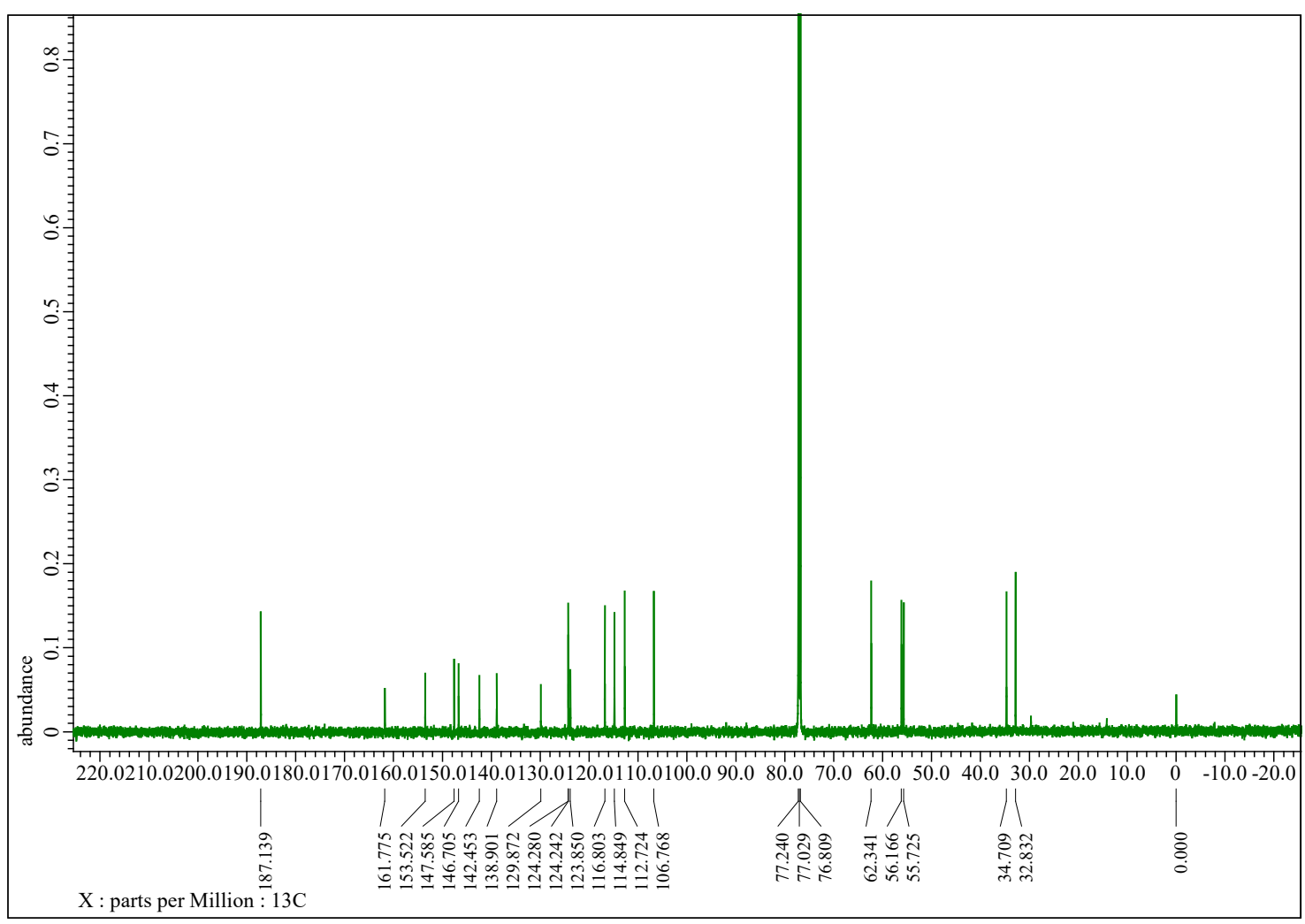


Figure S3. ${ }^{1} \mathrm{H}$ NMR spectrum of compound $\mathbf{5 E}\left(600 \mathrm{MHz}\right.$, in $\left.\mathrm{CDCl}_{3}\right)$

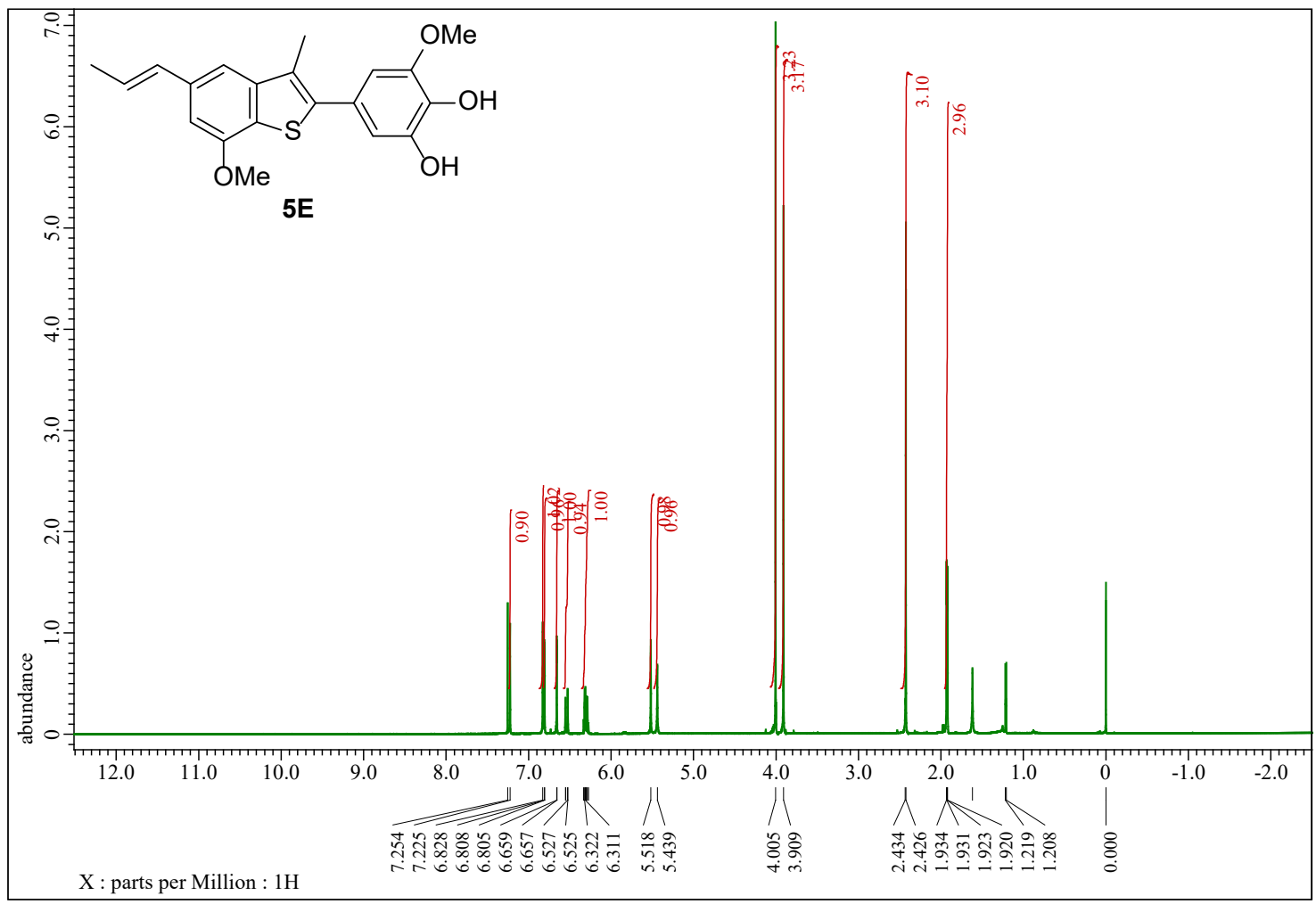

Figure S4. ${ }^{13} \mathrm{C}\left\{{ }^{1} \mathrm{H}\right\}$ NMR spectrum of compound $5 \mathbf{E}\left(150 \mathrm{MHz}\right.$, in $\left.\mathrm{CDCl}_{3}\right)$

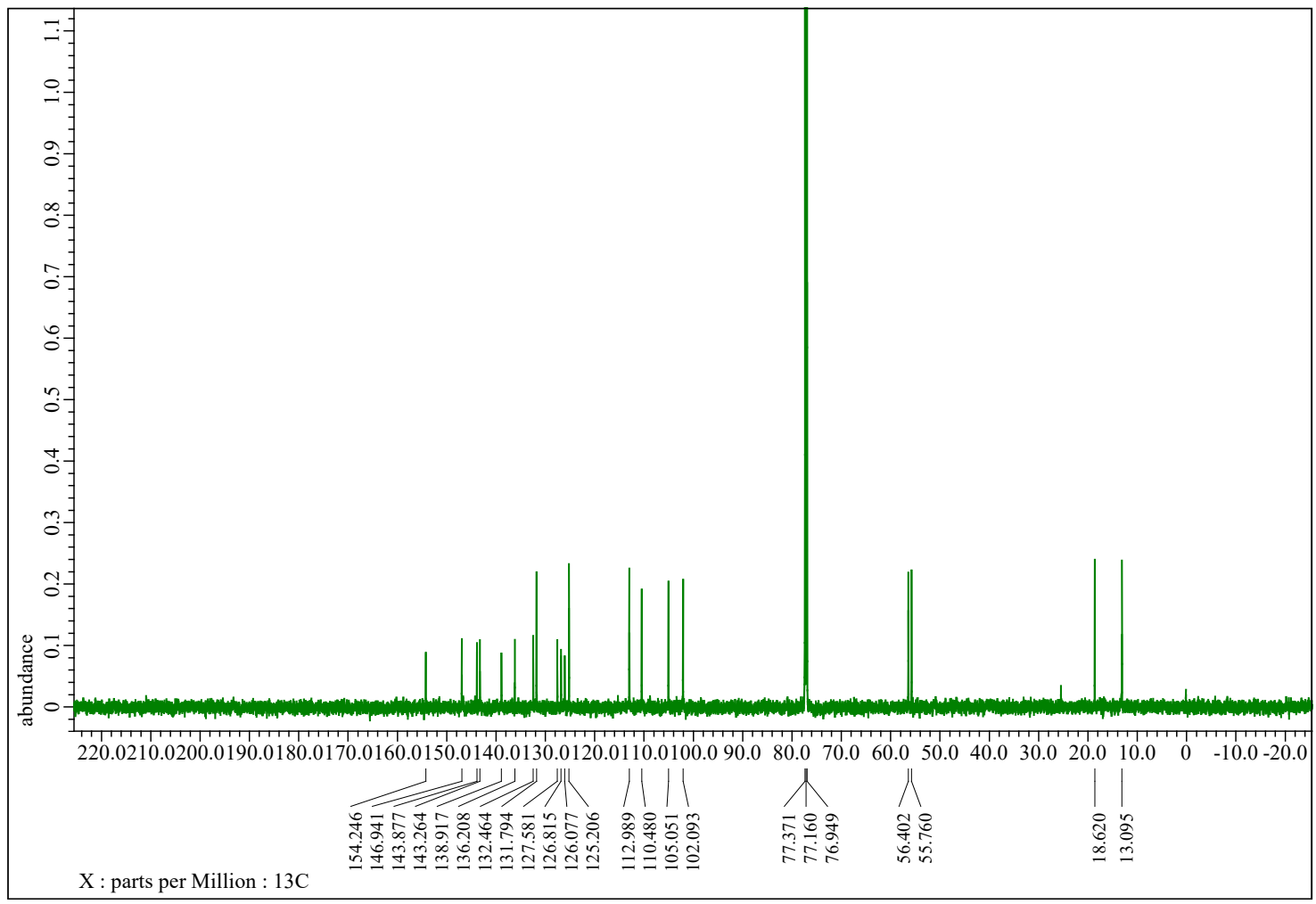


Figure S5. ${ }^{1} \mathrm{H}$ NMR spectrum of compound $\mathbf{5 Z}\left(600 \mathrm{MHz}\right.$, in $\left.\mathrm{CDCl}_{3}\right)$

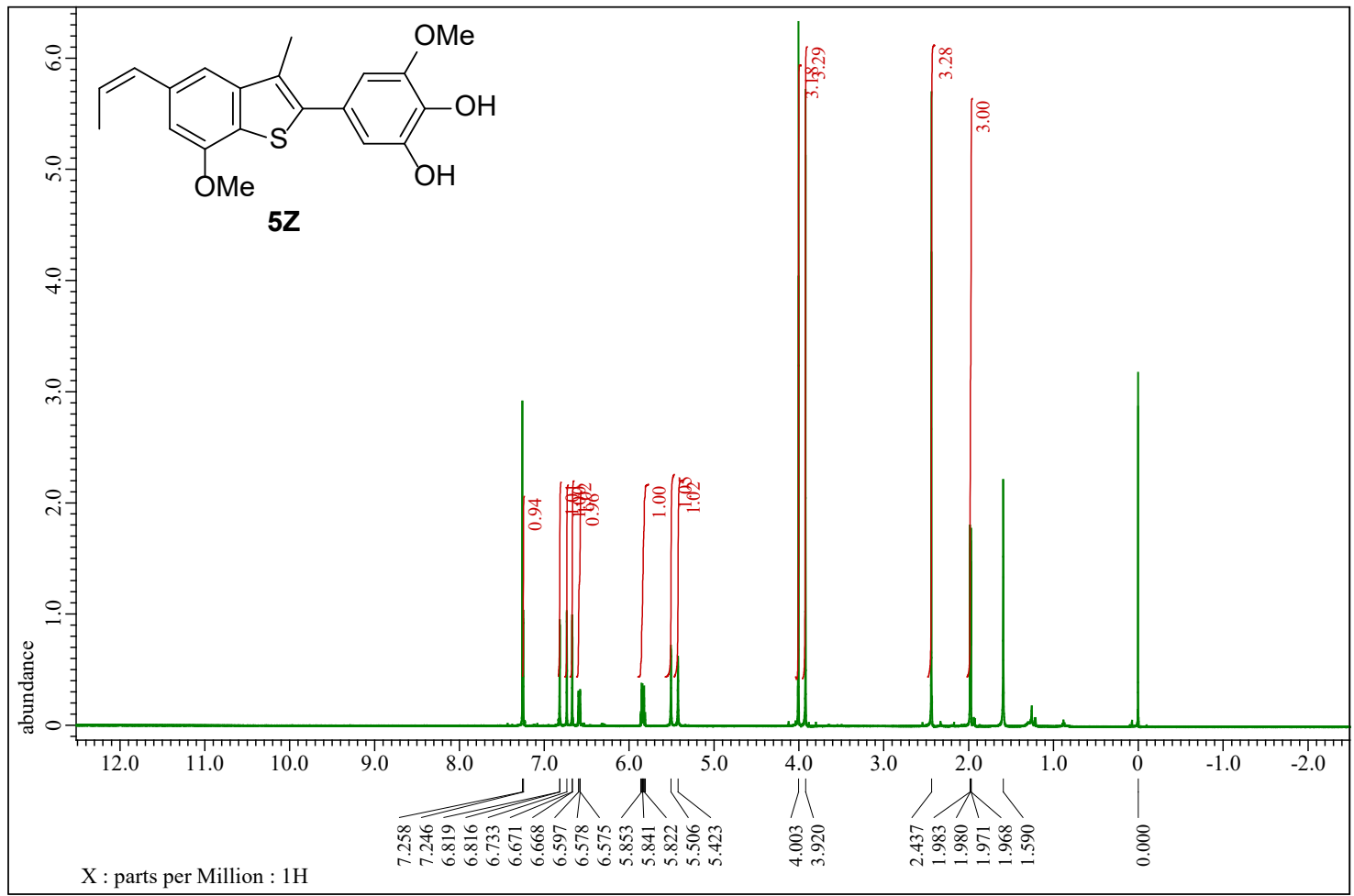

Figure S6. ${ }^{13} \mathrm{C}\left\{{ }^{1} \mathrm{H}\right\}$ NMR spectrum of compound $\mathbf{5 Z}\left(150 \mathrm{MHz}\right.$, in $\left.\mathrm{CDCl}_{3}\right)$

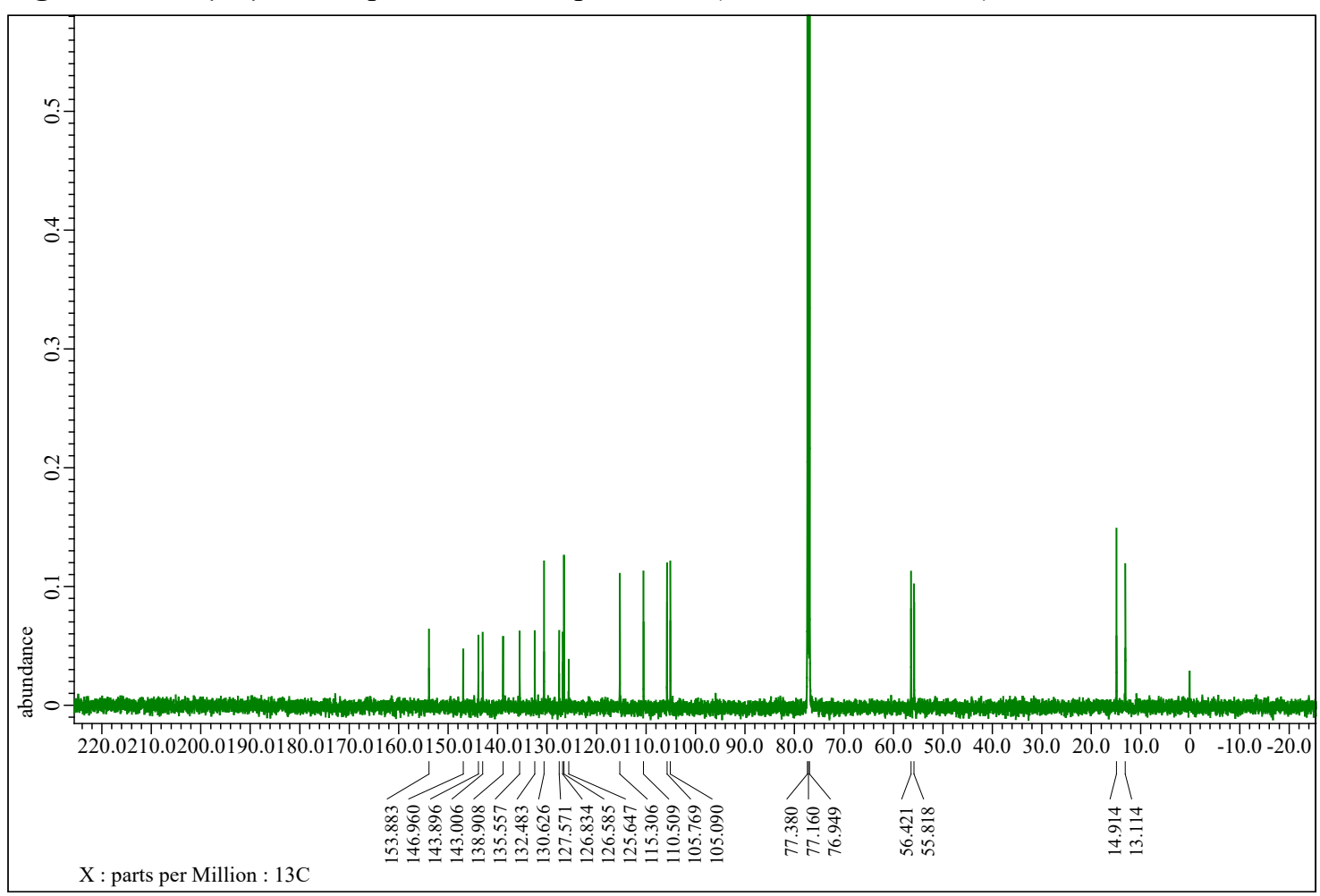


Figure S7. ${ }^{1} \mathrm{H}$ NMR spectrum of compound $6\left(400 \mathrm{MHz}\right.$, in $\left.\mathrm{CDCl}_{3}\right)$

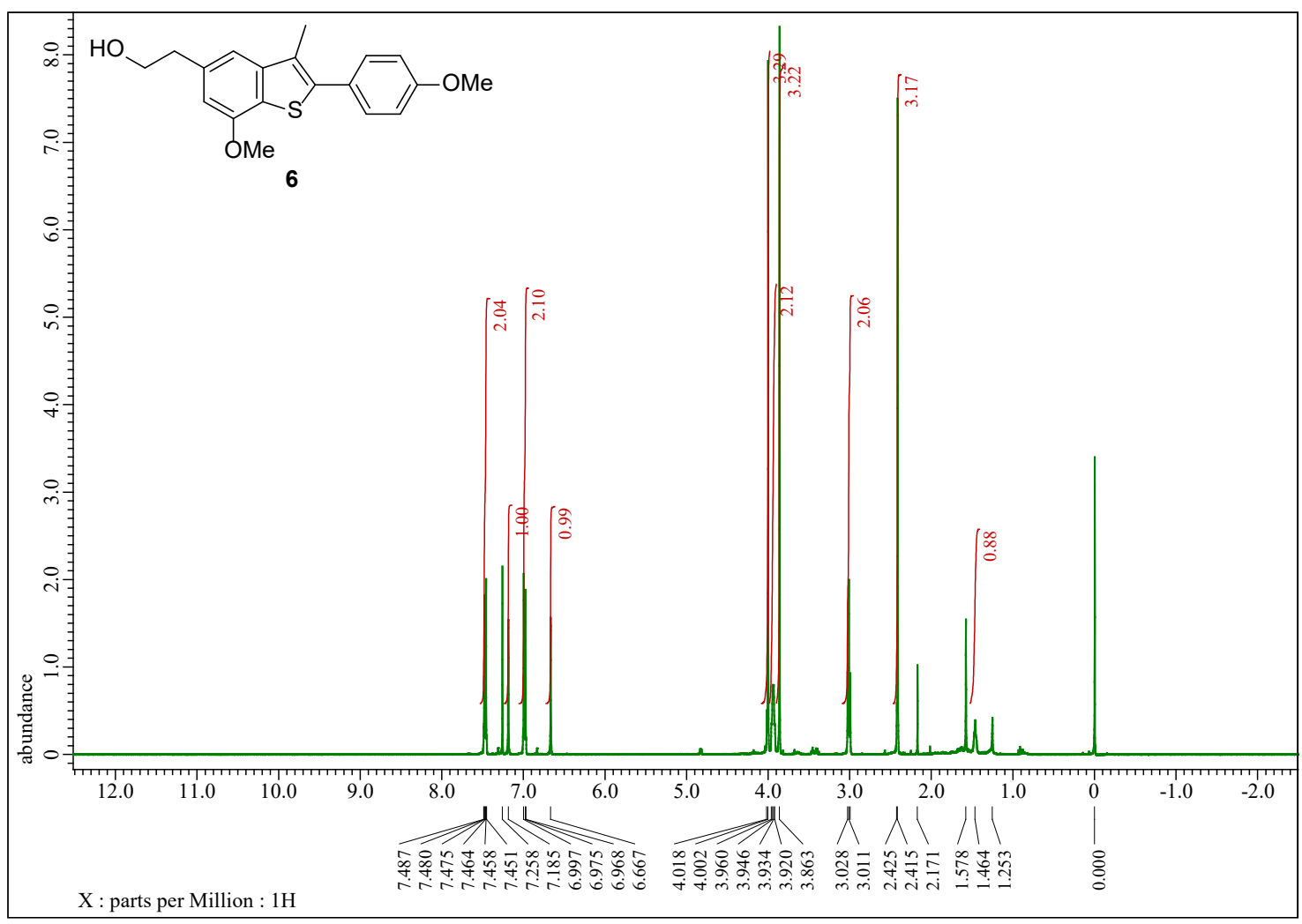

Figure S8. ${ }^{13} \mathrm{C}\left\{{ }^{1} \mathrm{H}\right\}$ NMR spectrum of compound $6\left(100 \mathrm{MHz}\right.$, in $\left.\mathrm{CDCl}_{3}\right)$

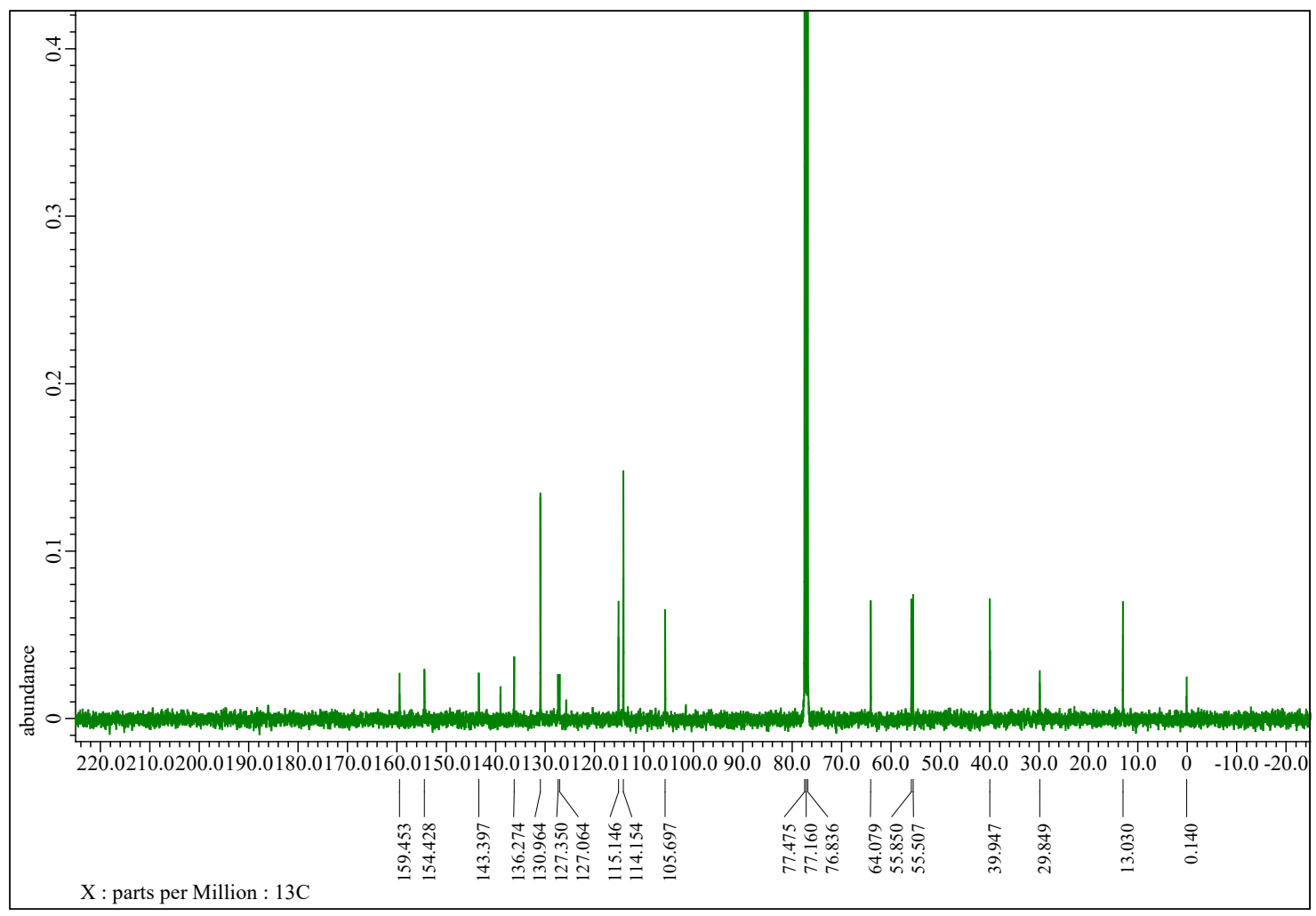


Figure S9. ${ }^{1} \mathrm{H}$ NMR spectrum of compound $10\left(600 \mathrm{MHz}\right.$, in $\left.\mathrm{CDCl}_{3}\right)$

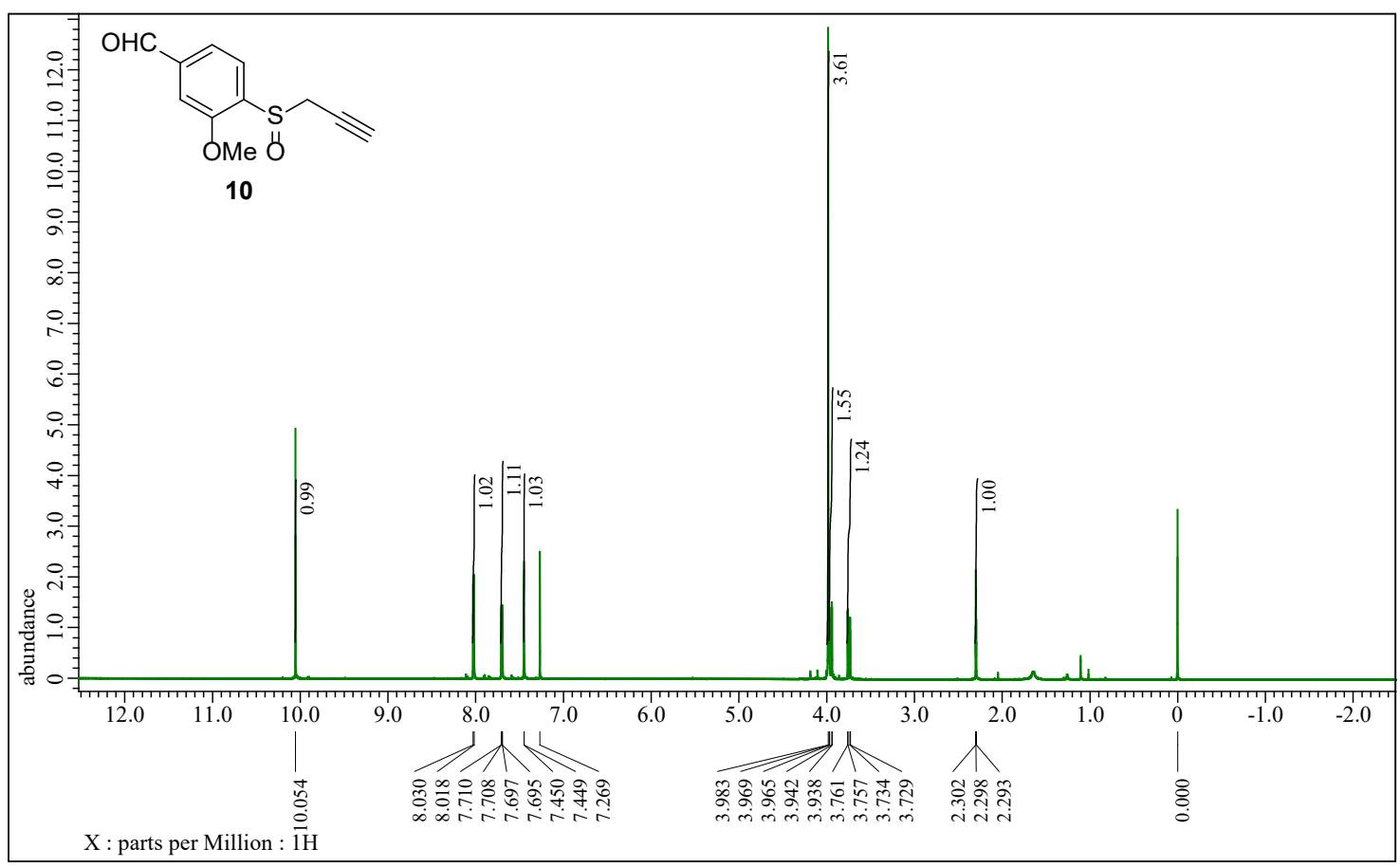

Figure S10. ${ }^{13} \mathrm{C}\left\{{ }^{1} \mathrm{H}\right\}$ NMR spectrum of compound $10\left(150 \mathrm{MHz}\right.$, in $\left.\mathrm{CDCl}_{3}\right)$

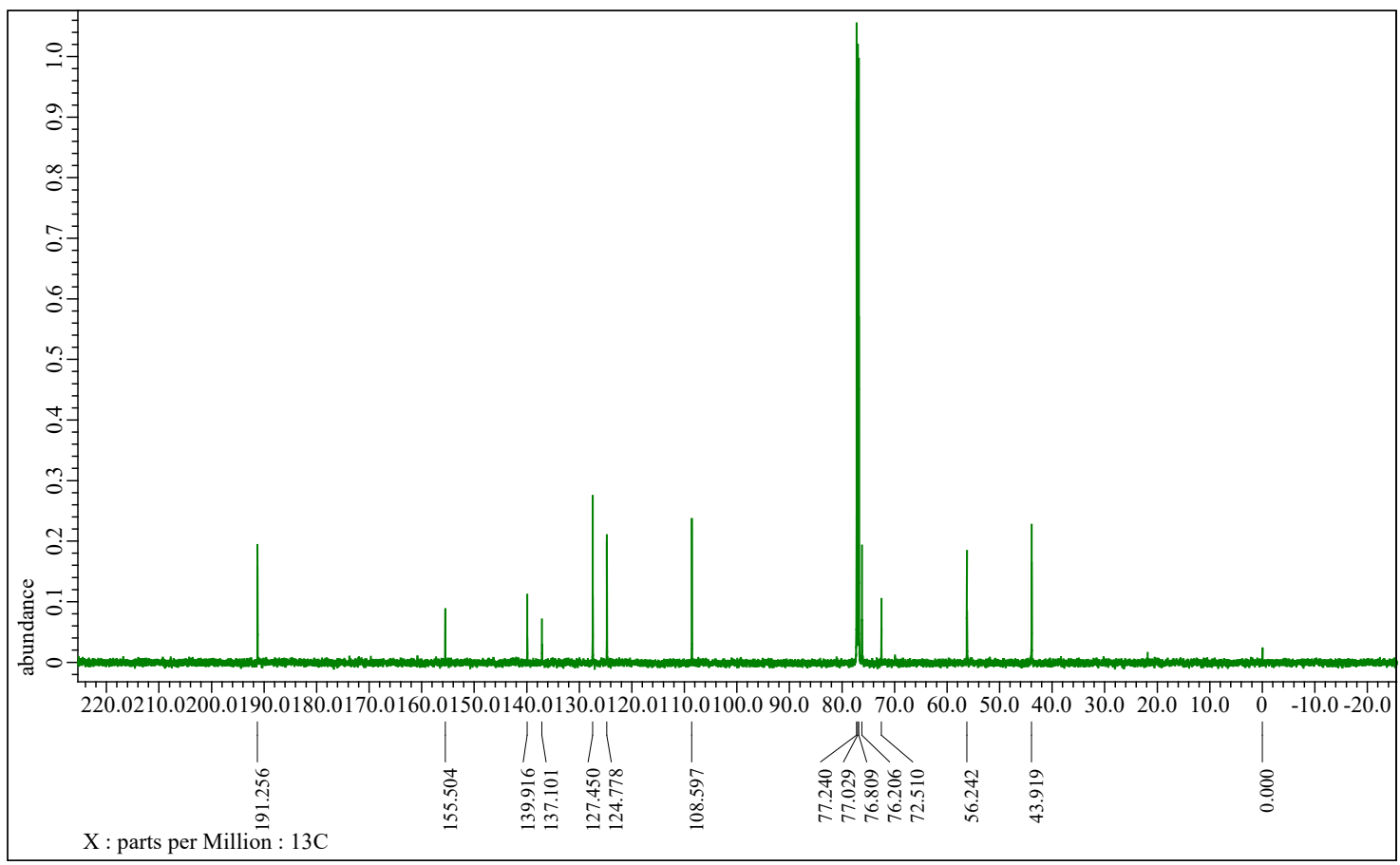


Figure S11. ${ }^{1} \mathrm{H}$ NMR spectrum of compound $11\left(600 \mathrm{MHz}\right.$, in $\left.\mathrm{CDCl}_{3}\right)$

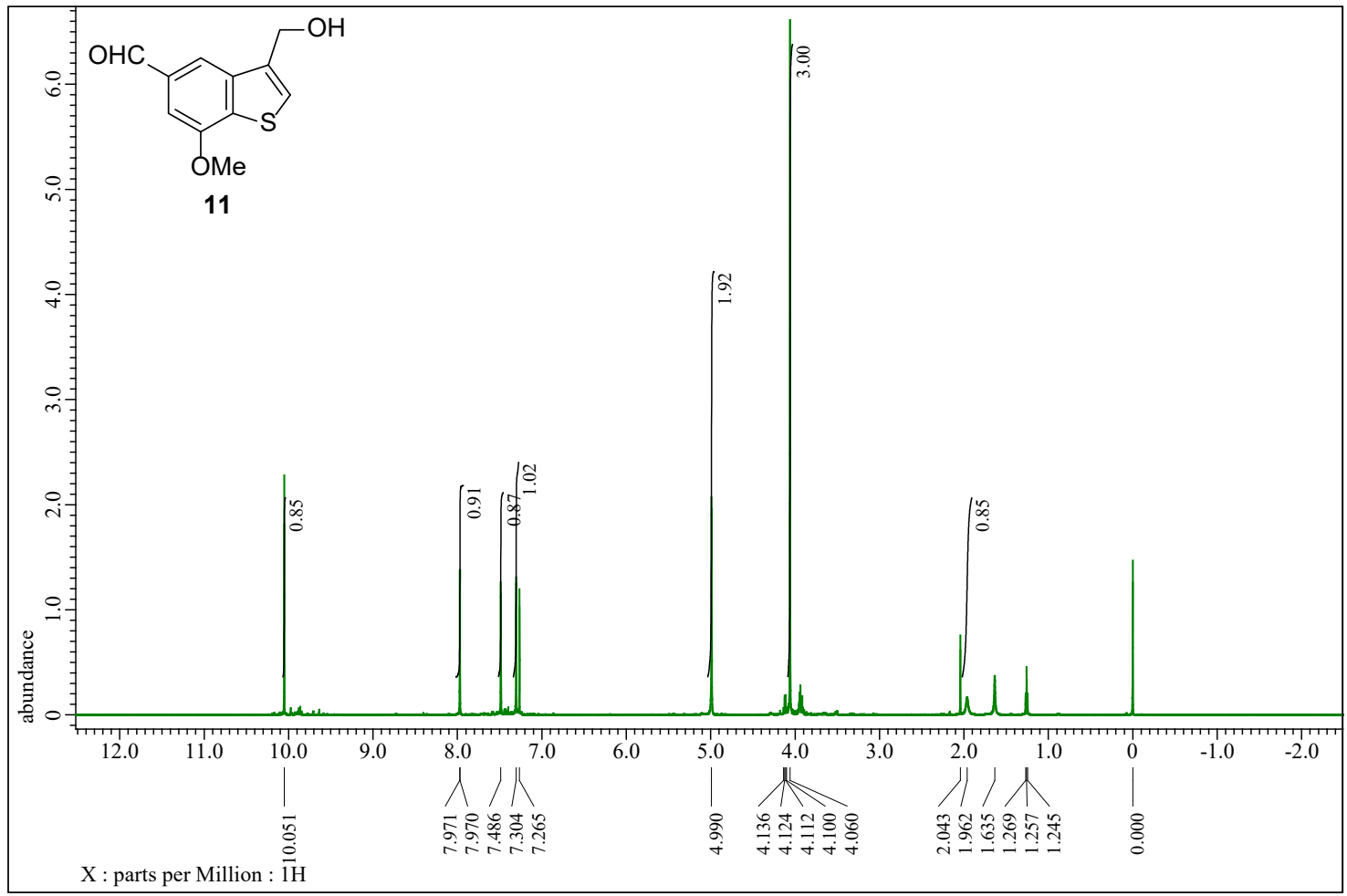

Figure S12. ${ }^{13} \mathrm{C}\left\{{ }^{1} \mathrm{H}\right\}$ NMR spectrum of compound $11\left(150 \mathrm{MHz}\right.$, in $\left.\mathrm{CDCl}_{3}\right)$

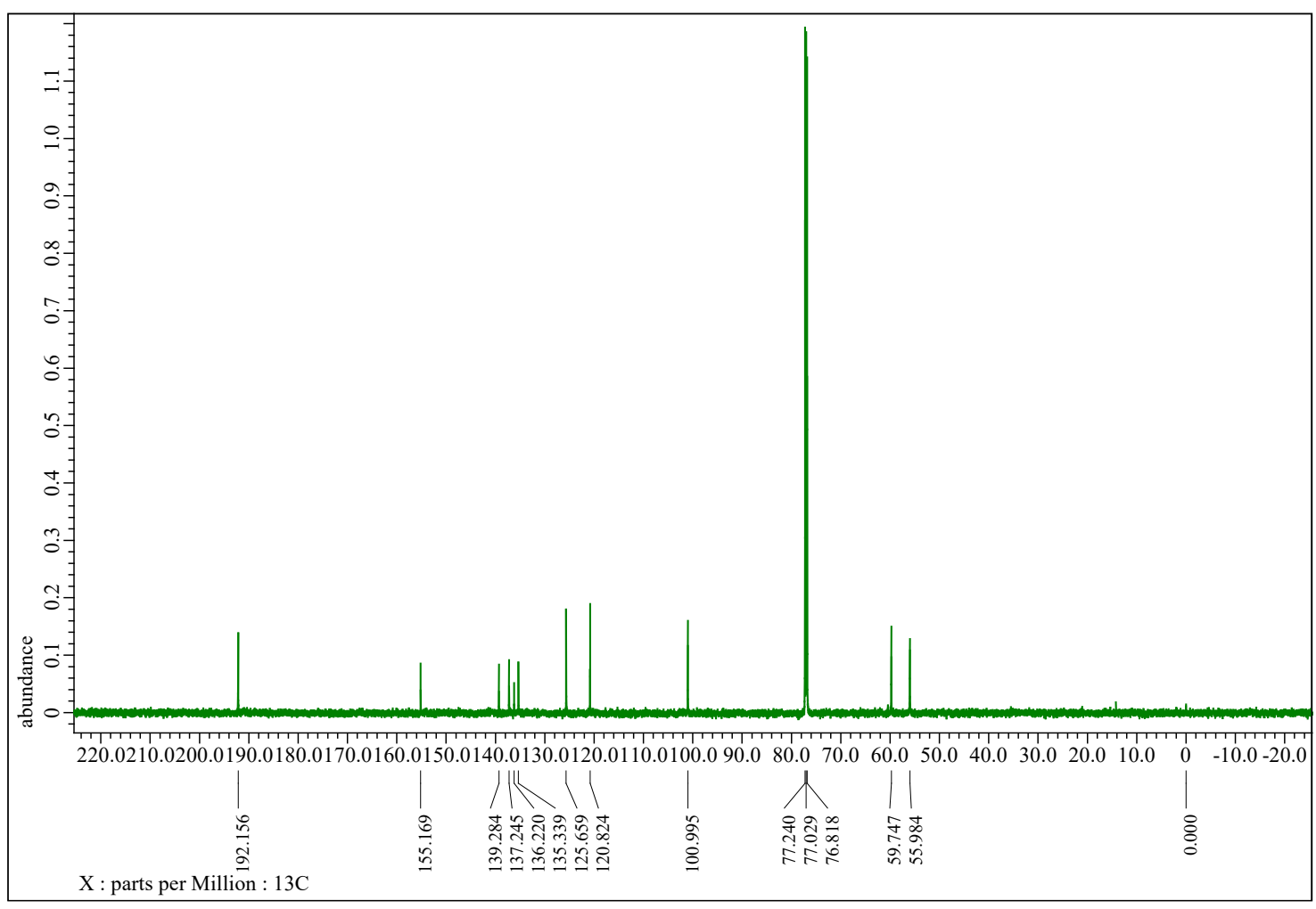


Figure S13. ${ }^{1} \mathrm{H}$ NMR spectrum of compound $12\left(600 \mathrm{MHz}\right.$, in $\left.\mathrm{CDCl}_{3}\right)$

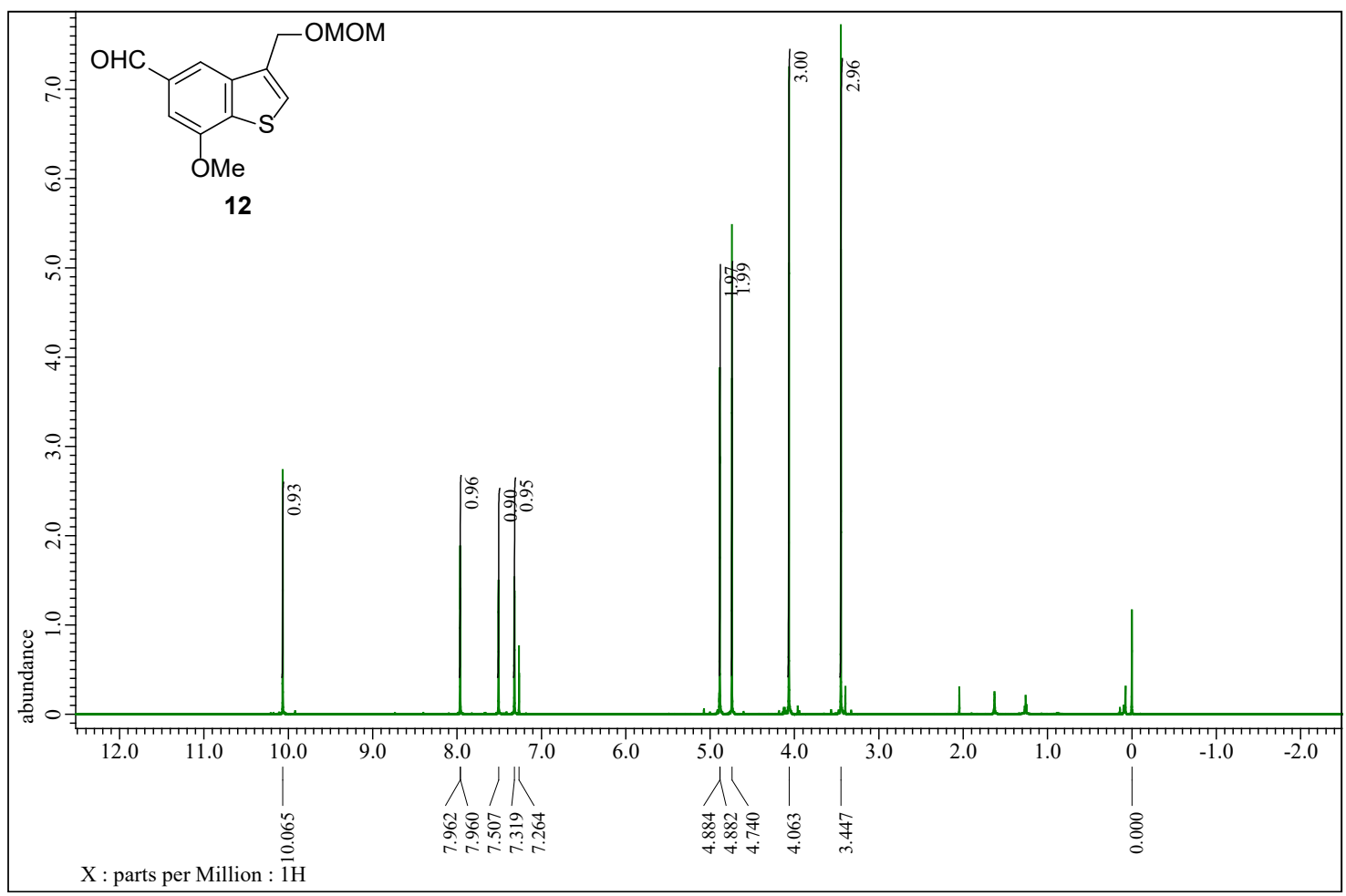

Figure S14. ${ }^{13} \mathrm{C}\left\{{ }^{1} \mathrm{H}\right\}$ NMR spectrum of compound $12\left(150 \mathrm{MHz}\right.$, in $\left.\mathrm{CDCl}_{3}\right)$

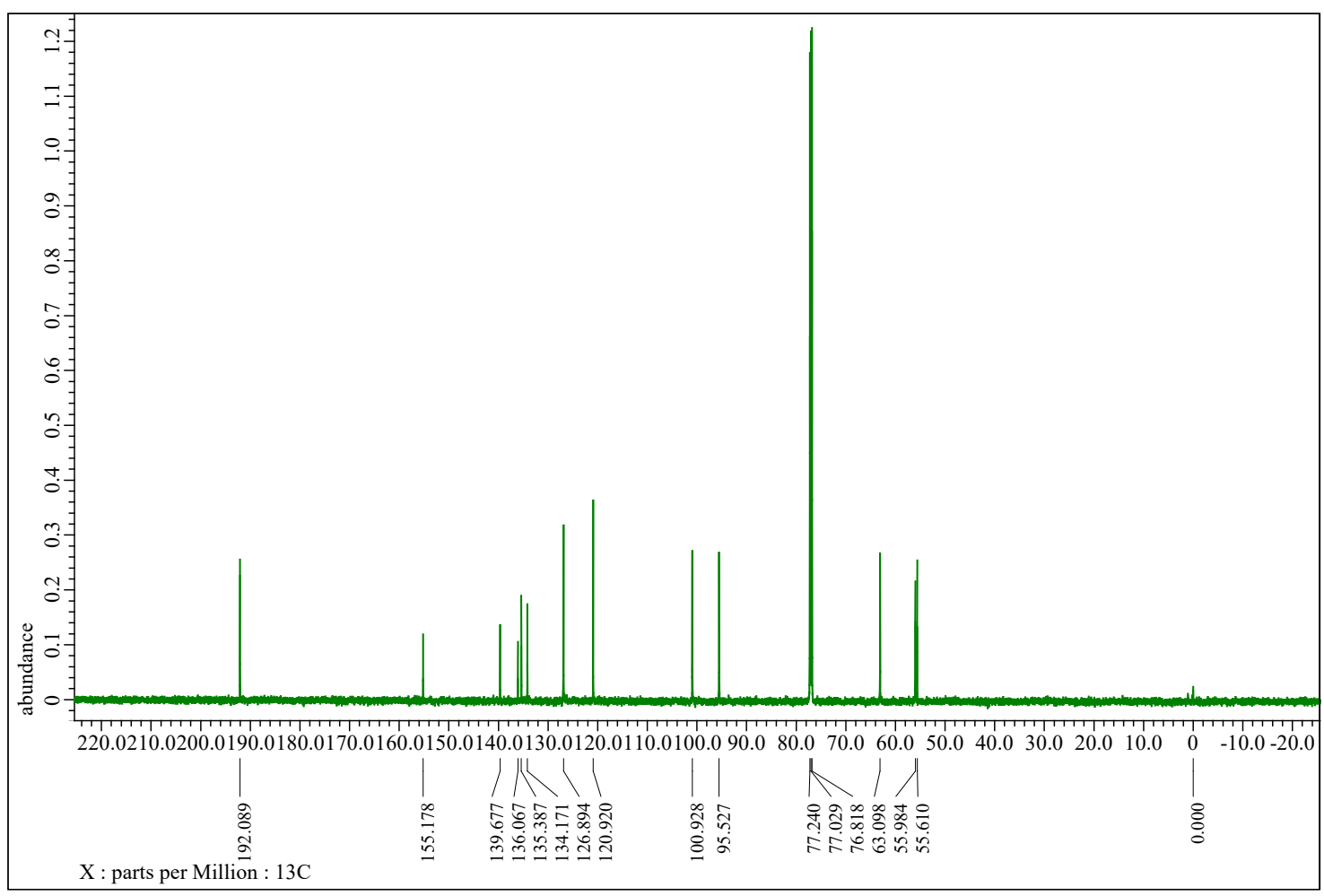


Figure S15. ${ }^{1} \mathrm{H}$ NMR spectrum of compound $13\left(600 \mathrm{MHz}\right.$, in $\left.\mathrm{CDCl}_{3}\right)$

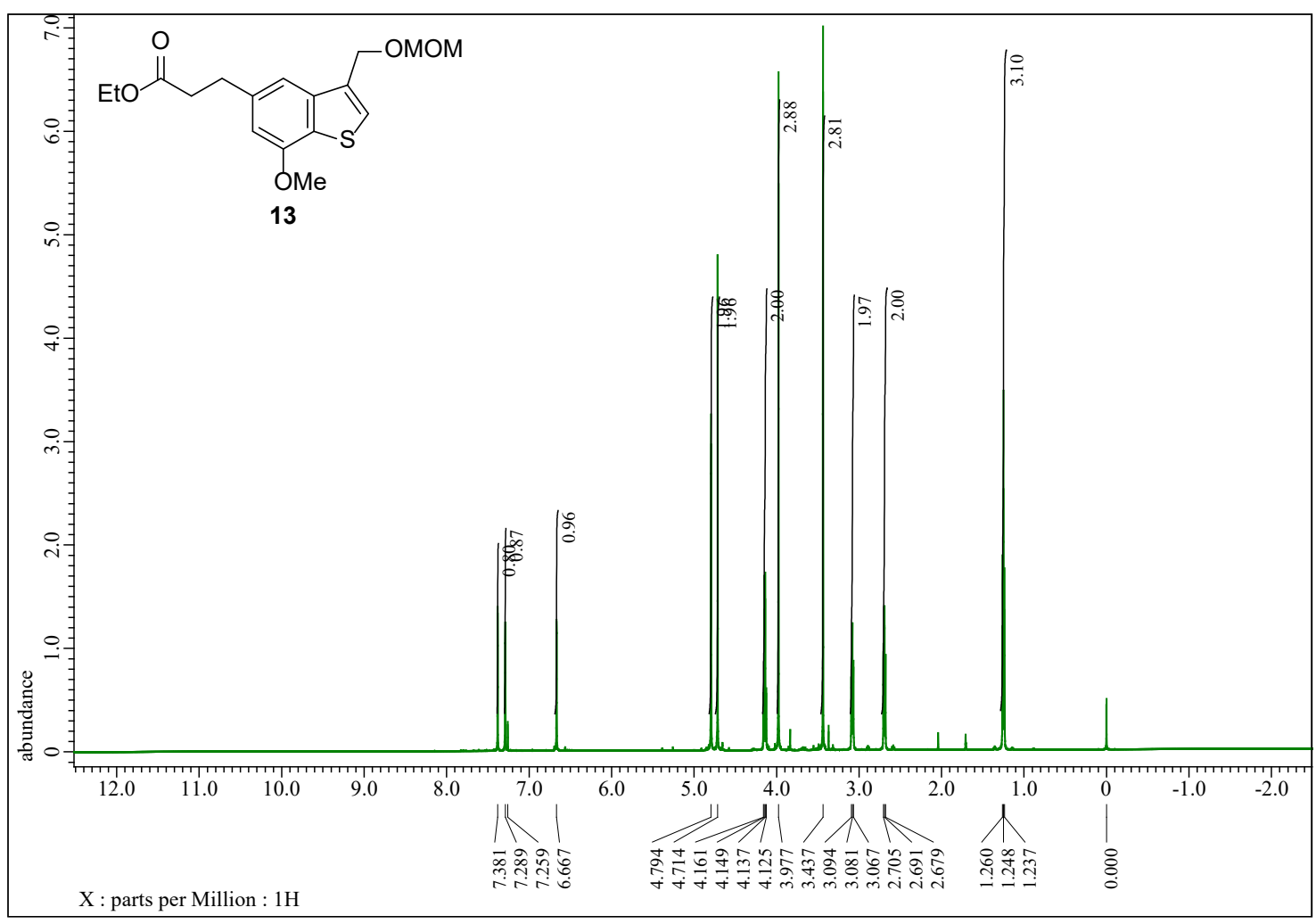

Figure S16. ${ }^{13} \mathrm{C}\left\{{ }^{1} \mathrm{H}\right\}$ NMR spectrum of compound $13\left(150 \mathrm{MHz}\right.$, in $\left.\mathrm{CDCl}_{3}\right)$

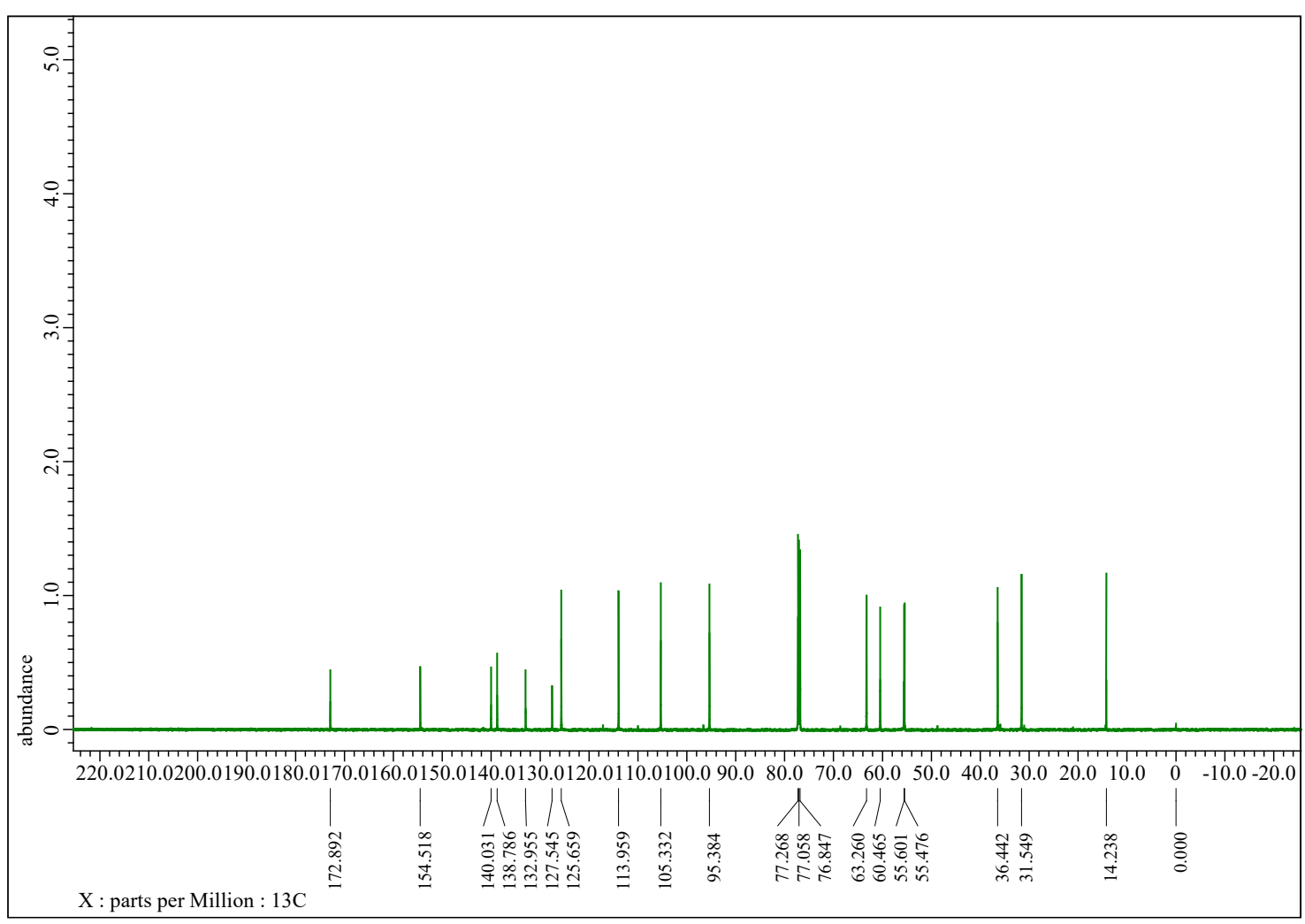


Figure S17. ${ }^{1} \mathrm{H}$ NMR spectrum of compound $14\left(600 \mathrm{MHz}\right.$, in $\left.\mathrm{CDCl}_{3}\right)$

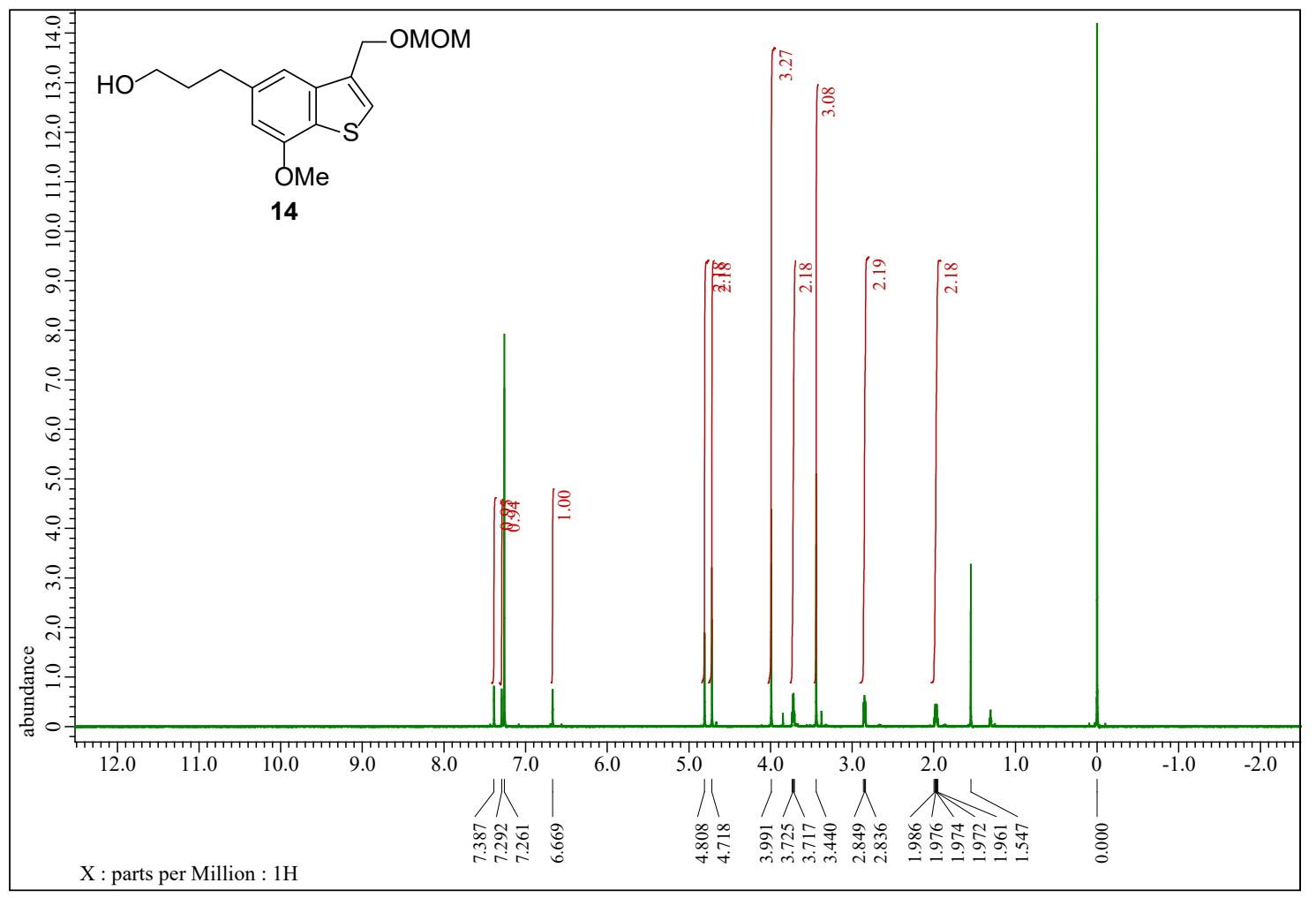

Figure S18. ${ }^{13} \mathrm{C}\left\{{ }^{1} \mathrm{H}\right\}$ NMR spectrum of compound $14\left(150 \mathrm{MHz}\right.$, in $\left.\mathrm{CDCl}_{3}\right)$

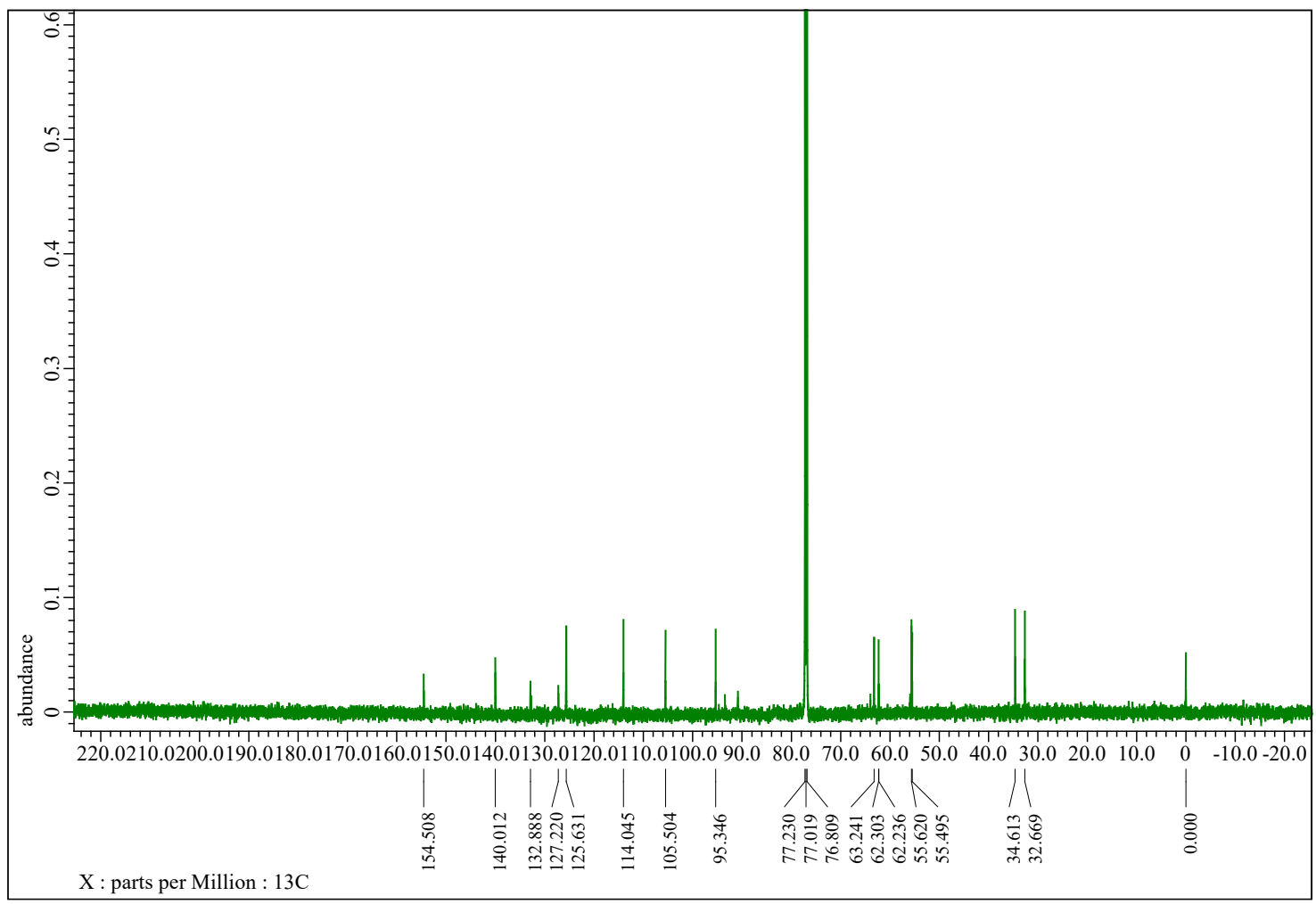


Figure S19. ${ }^{1} \mathrm{H}$ NMR spectrum of compound $15\left(600 \mathrm{MHz}\right.$, in $\left.\mathrm{CDCl}_{3}\right)$

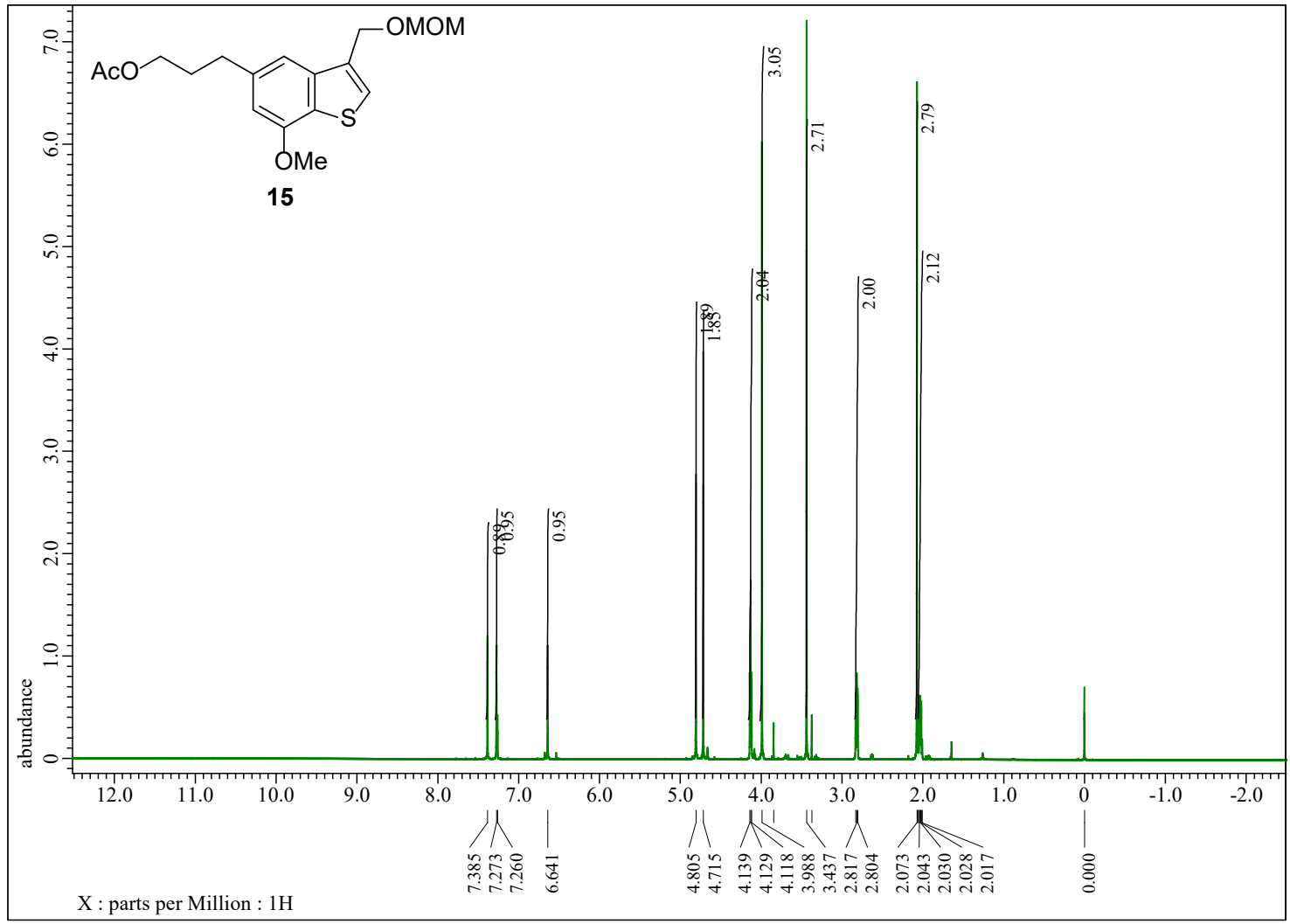

Figure S20. ${ }^{13} \mathrm{C}\left\{{ }^{1} \mathrm{H}\right\}$ NMR spectrum of compound $15\left(150 \mathrm{MHz}\right.$, in $\left.\mathrm{CDCl}_{3}\right)$

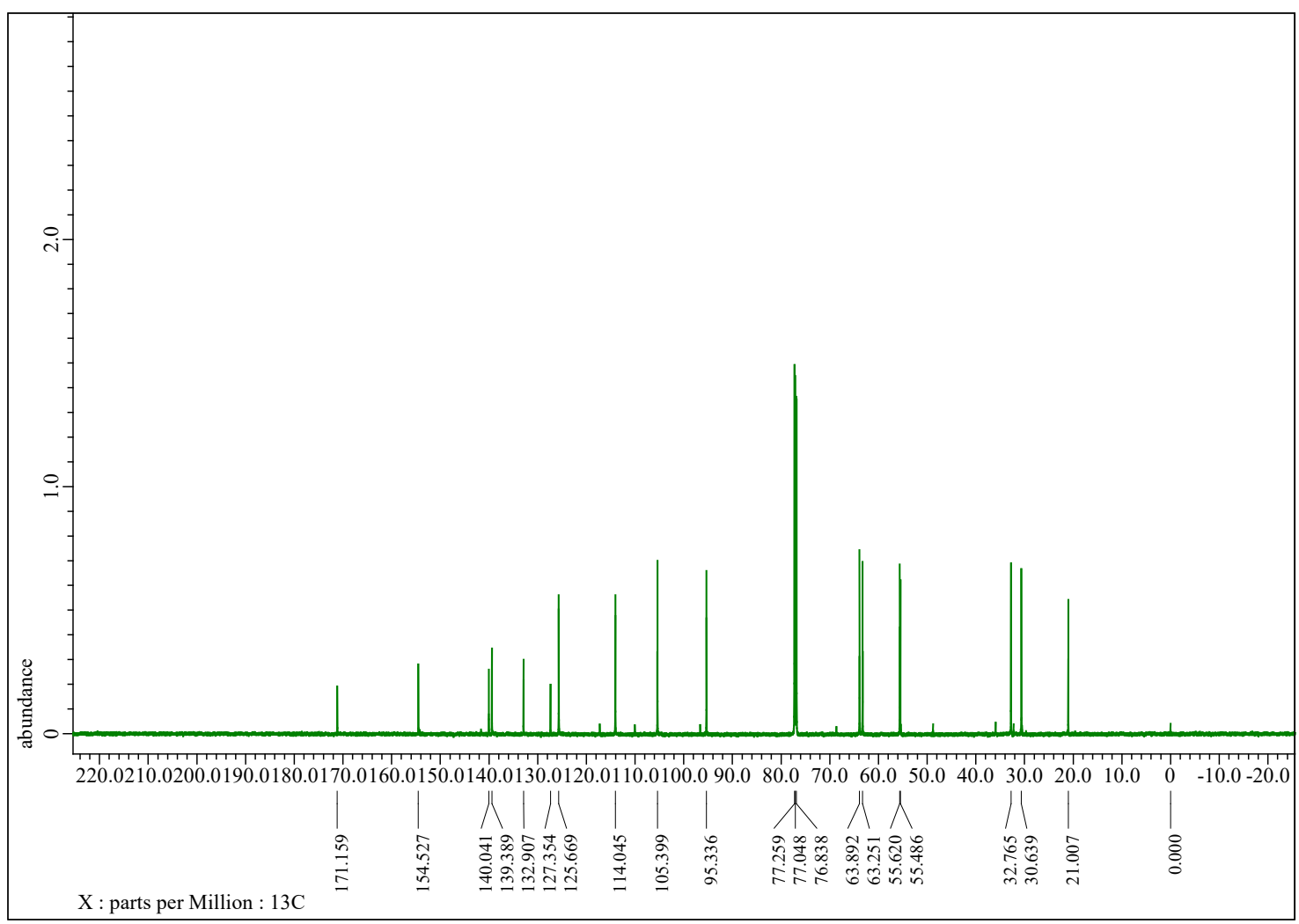


Figure S21. ${ }^{1} \mathrm{H}$ NMR spectrum of compound $16\left(400 \mathrm{MHz}\right.$, in $\left.\mathrm{CDCl}_{3}\right)$

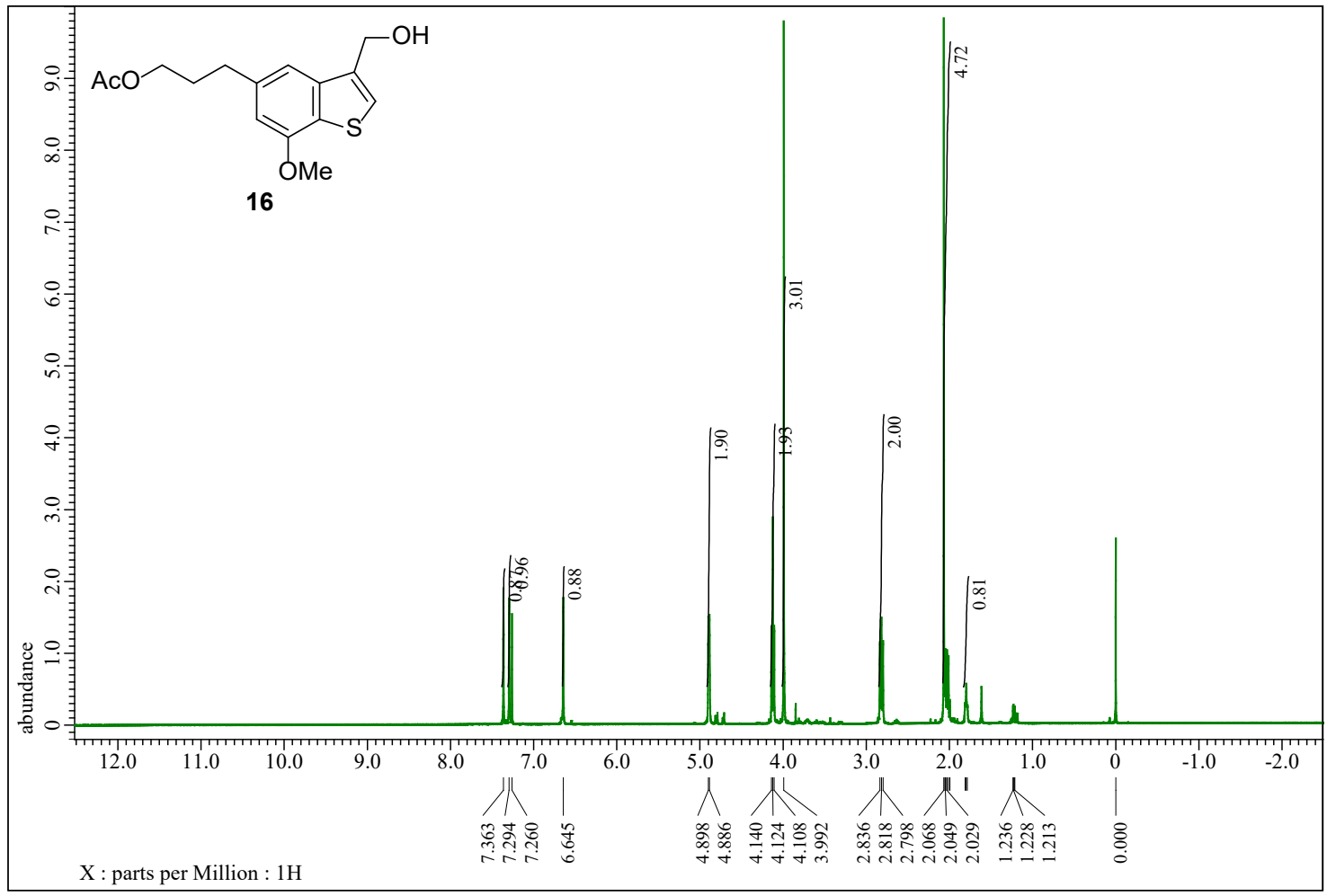

Figure S22. ${ }^{13} \mathrm{C}\left\{{ }^{1} \mathrm{H}\right\}$ NMR spectrum of compound $16\left(150 \mathrm{MHz}\right.$, in $\left.\mathrm{CDCl}_{3}\right)$

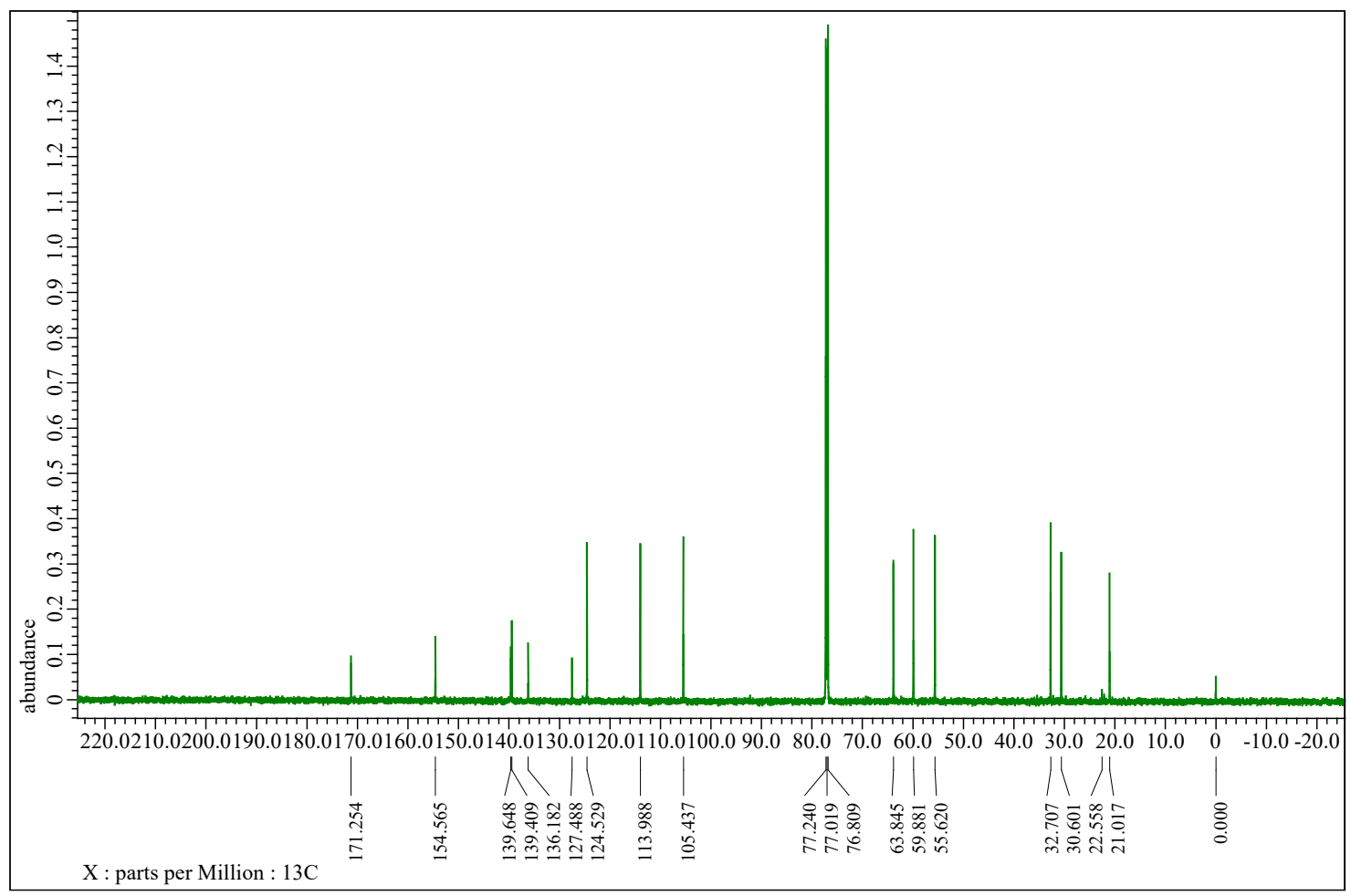


Figure S23. ${ }^{1} \mathrm{H}$ NMR spectrum of compound $17\left(400 \mathrm{MHz}\right.$, in $\left.\mathrm{CDCl}_{3}\right)$

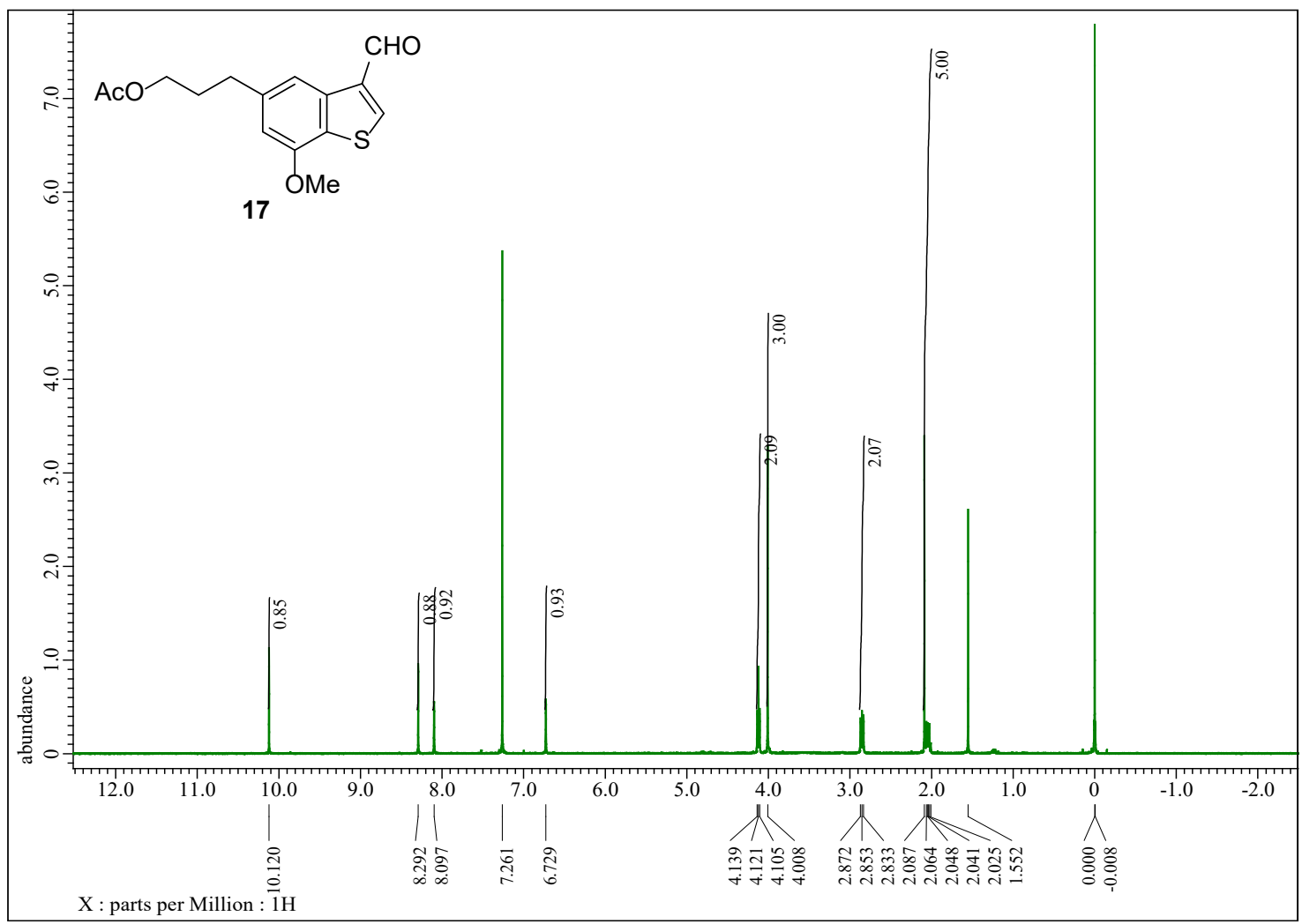

Figure S24. ${ }^{13} \mathrm{C}\left\{{ }^{1} \mathrm{H}\right\}$ NMR spectrum of compound $17\left(150 \mathrm{MHz}\right.$, in $\left.\mathrm{CDCl}_{3}\right)$

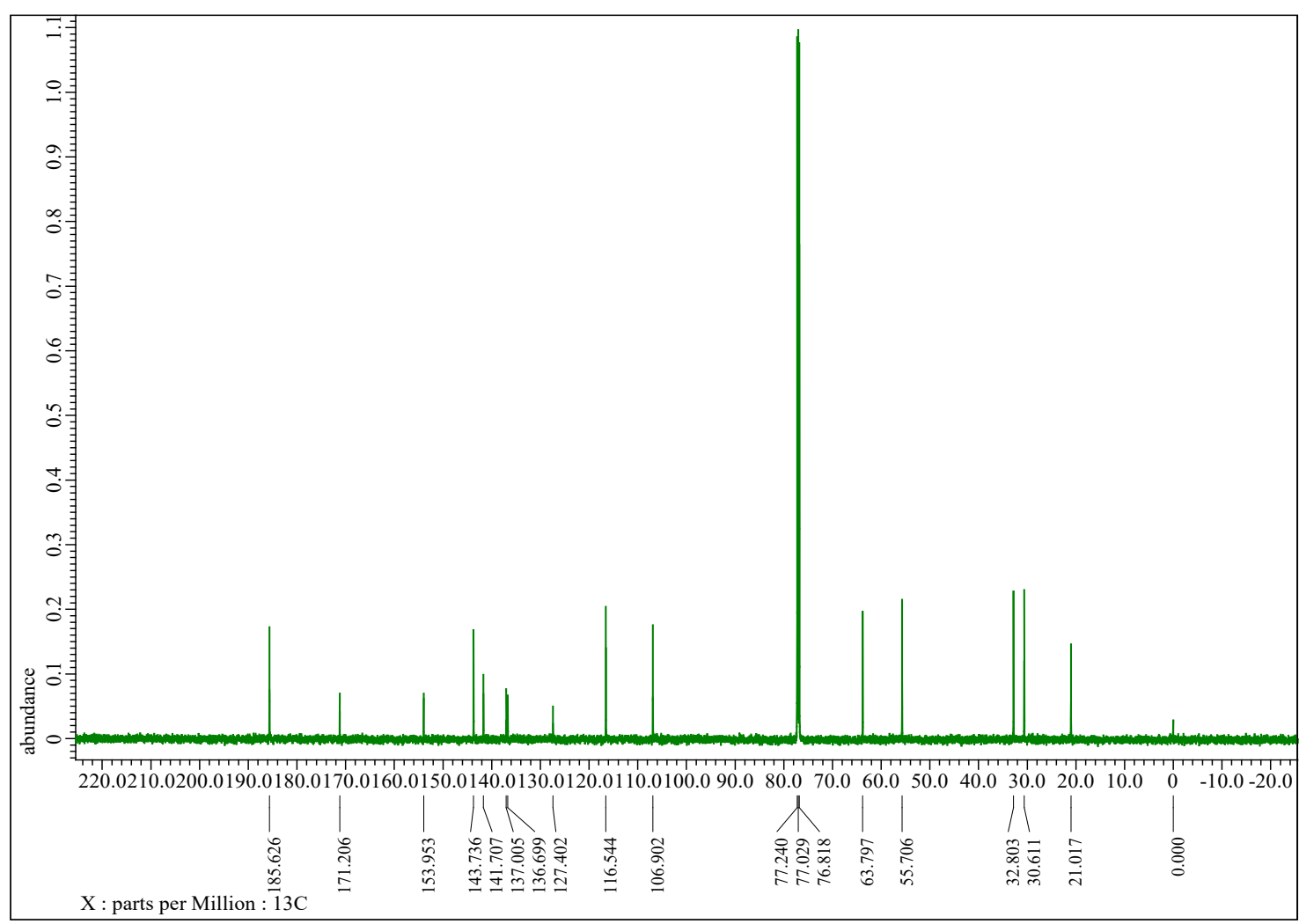


Figure S25. ${ }^{1} \mathrm{H}$ NMR spectrum of compound $18\left(600 \mathrm{MHz}\right.$, in $\left.\mathrm{CDCl}_{3}\right)$

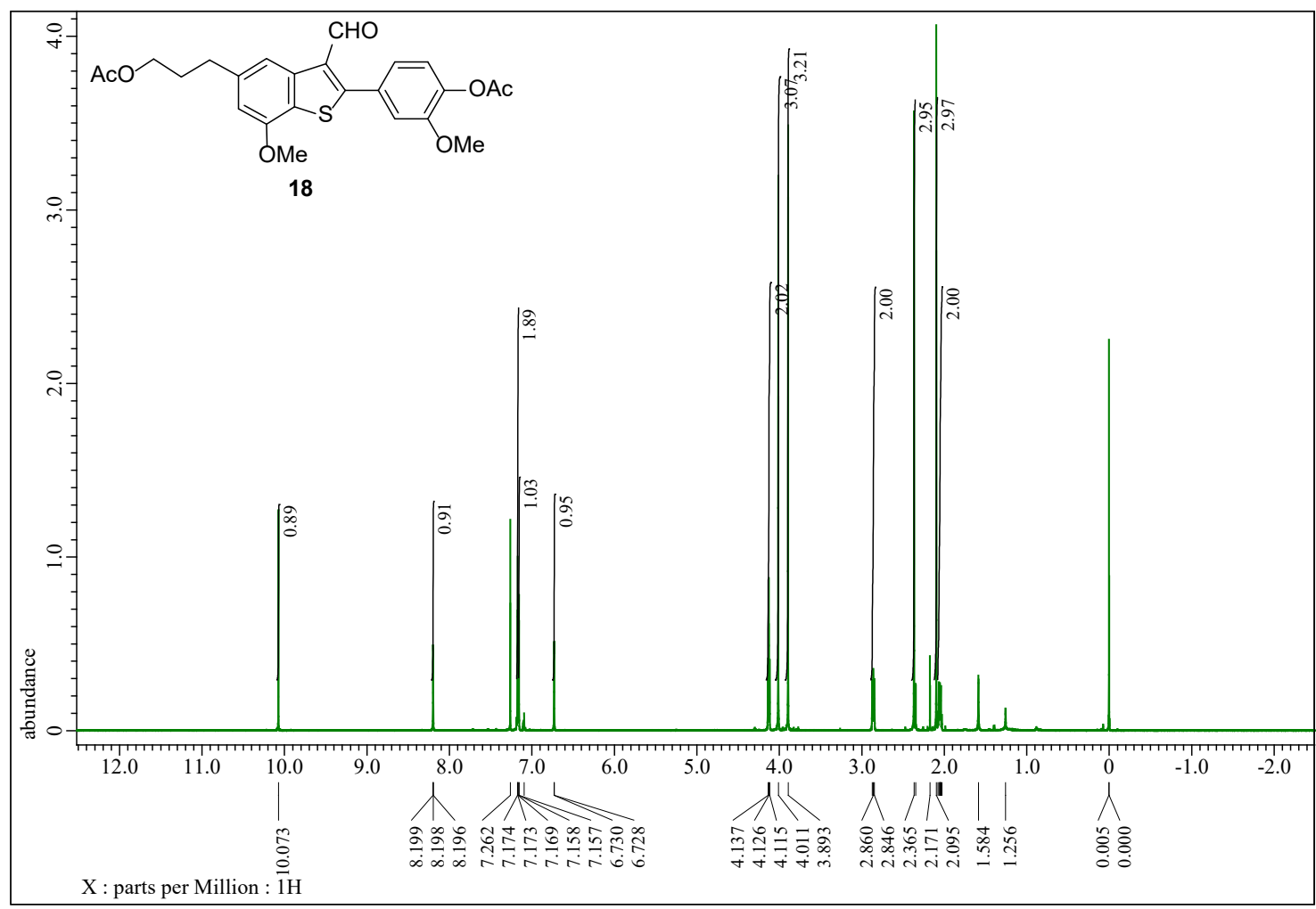

Figure S26. ${ }^{13} \mathrm{C}\left\{{ }^{1} \mathrm{H}\right\}$ NMR spectrum of compound $18\left(150 \mathrm{MHz}\right.$, in $\left.\mathrm{CDCl}_{3}\right)$

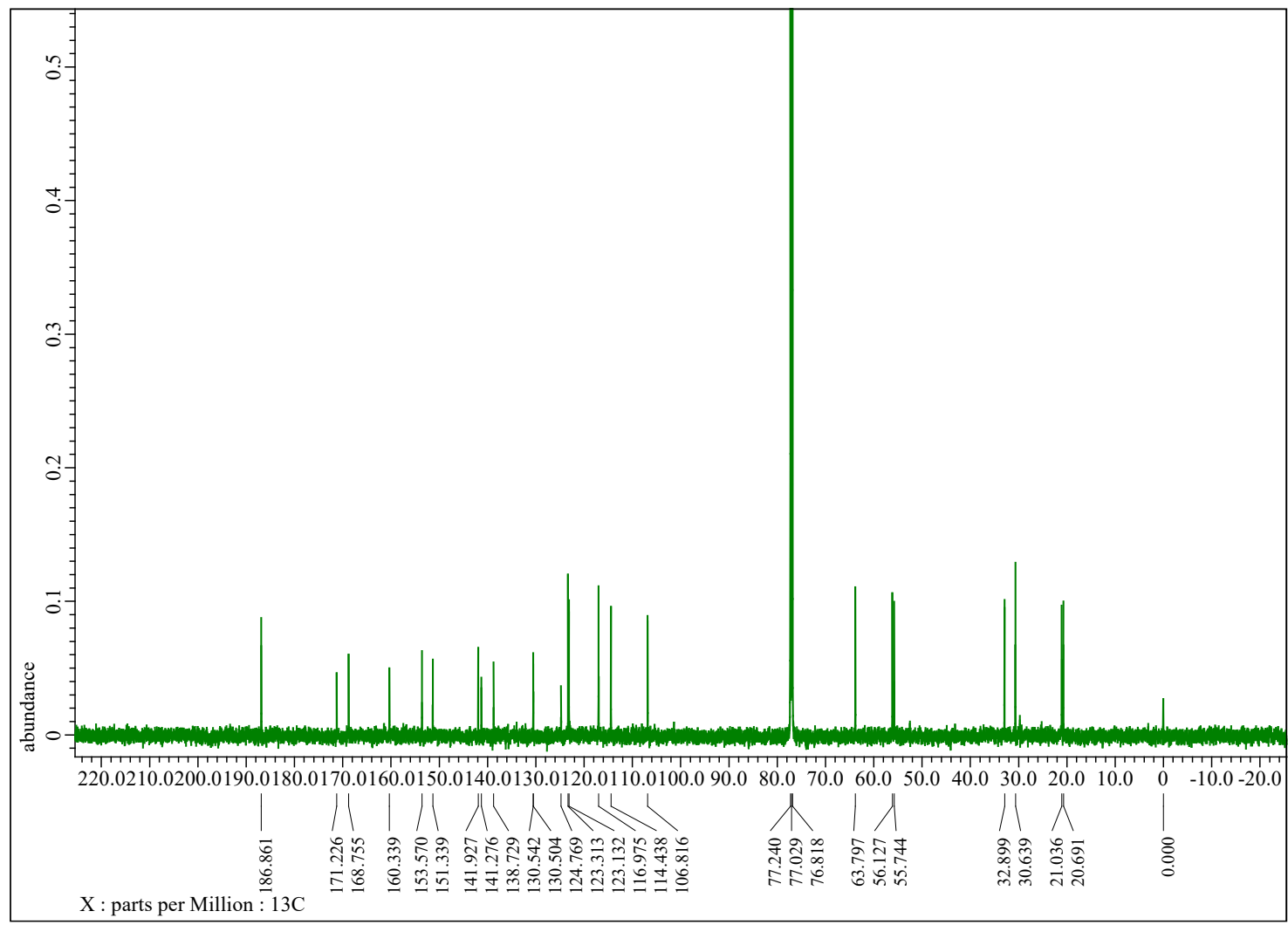


Figure S27. ${ }^{1} \mathrm{H}$ NMR spectrum of compound $19\left(400 \mathrm{MHz}\right.$, in $\left.\mathrm{CDCl}_{3}\right)$

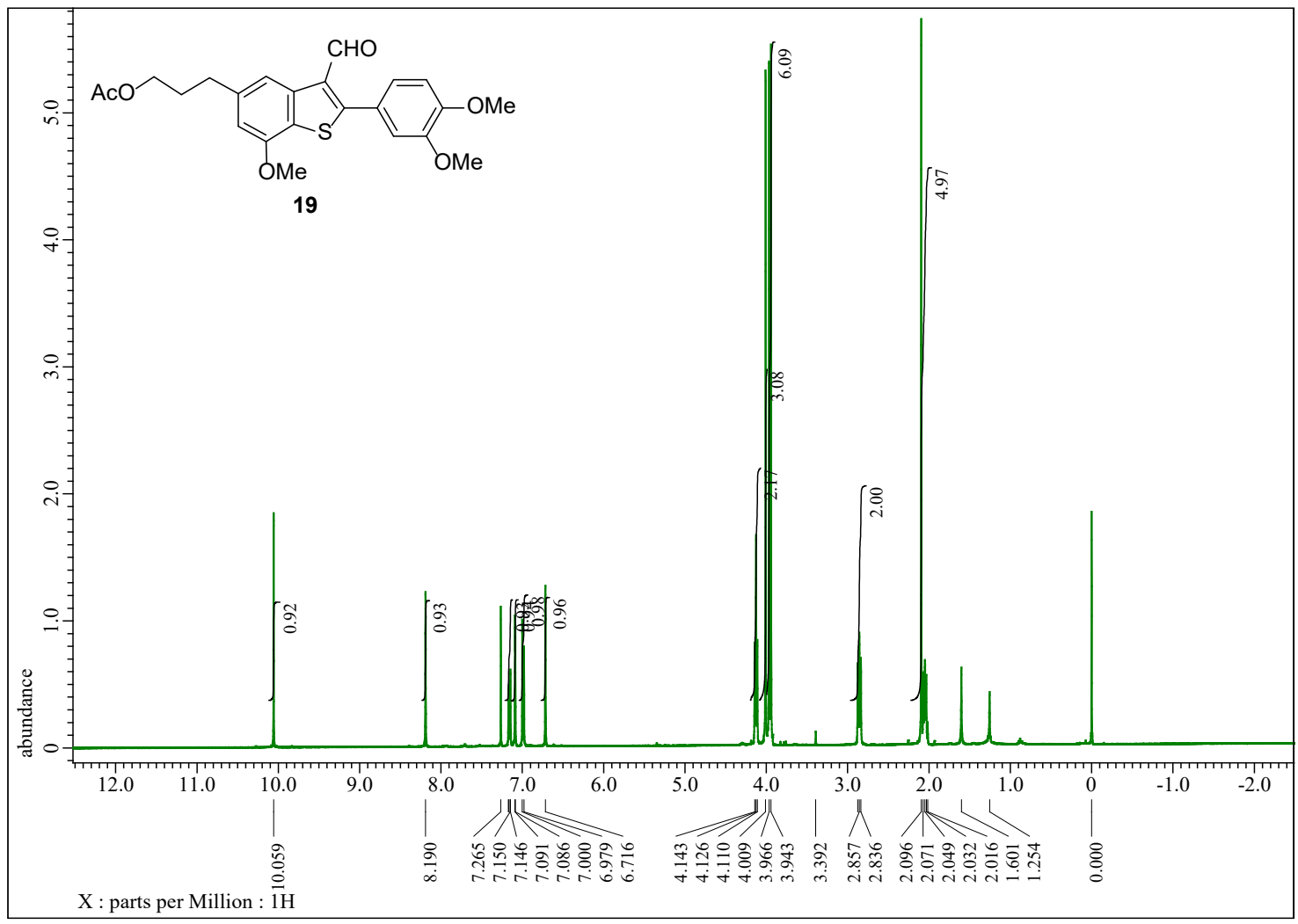

Figure S28. ${ }^{13} \mathrm{C}\left\{{ }^{1} \mathrm{H}\right\}$ NMR spectrum of compound $18\left(150 \mathrm{MHz}\right.$, in $\left.\mathrm{CDCl}_{3}\right)$

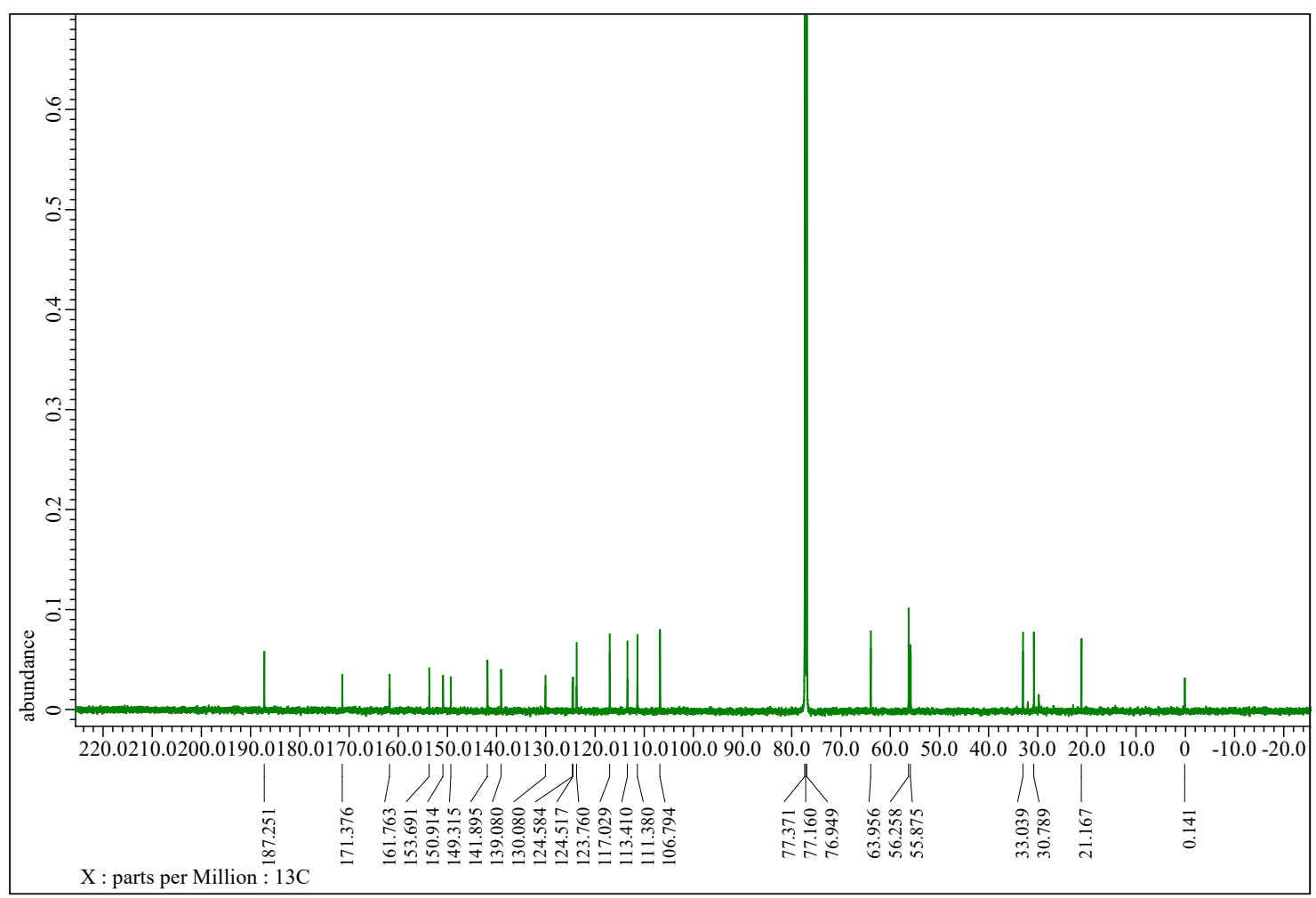


Figure S29. ${ }^{1} \mathrm{H}$ NMR spectrum of compound $20\left(600 \mathrm{MHz}\right.$, in $\left.\mathrm{CDCl}_{3}\right)$

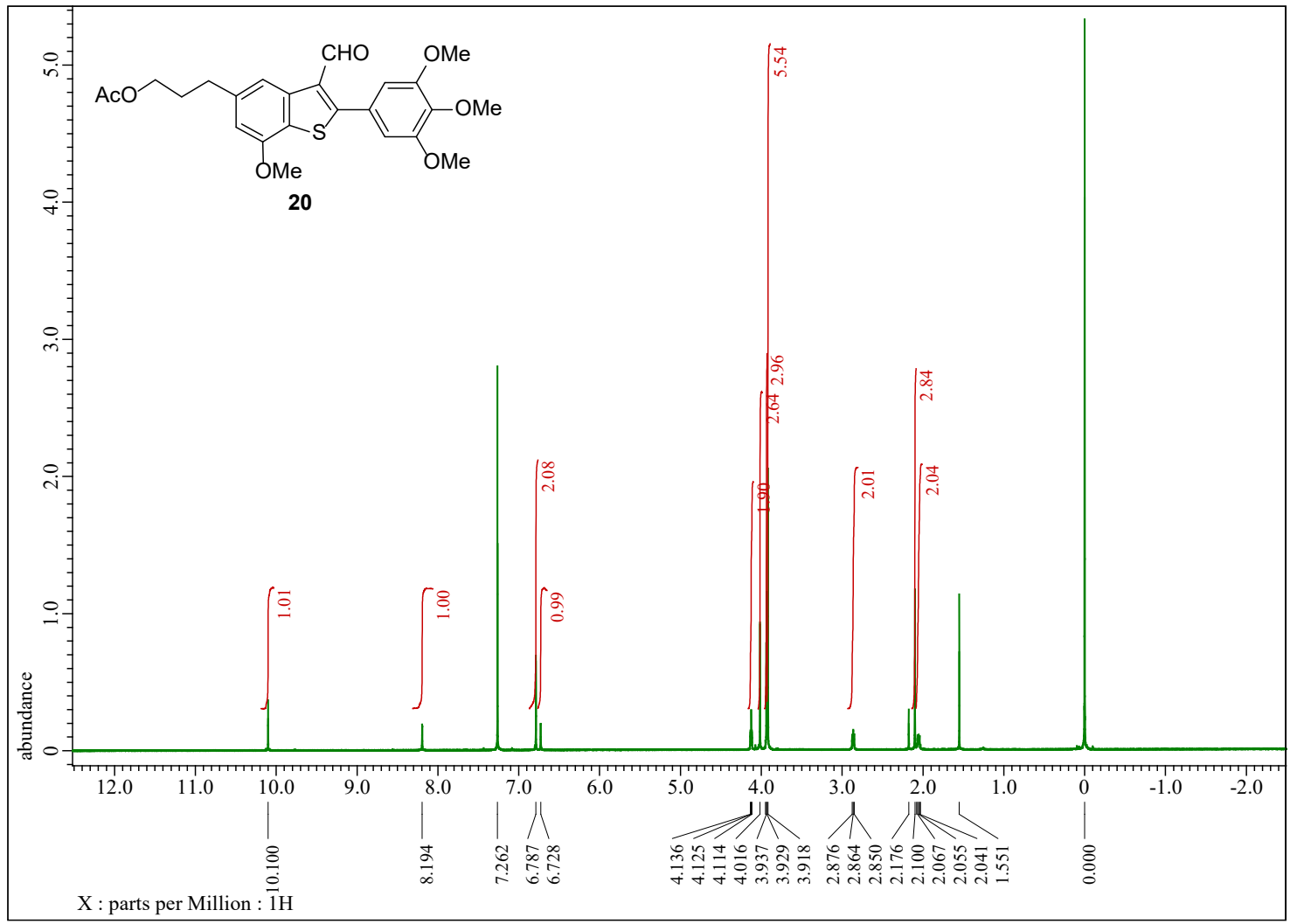

Figure S30. ${ }^{13} \mathrm{C}\left\{{ }^{1} \mathrm{H}\right\}$ NMR spectrum of compound $20\left(150 \mathrm{MHz}\right.$, in $\left.\mathrm{CDCl}_{3}\right)$

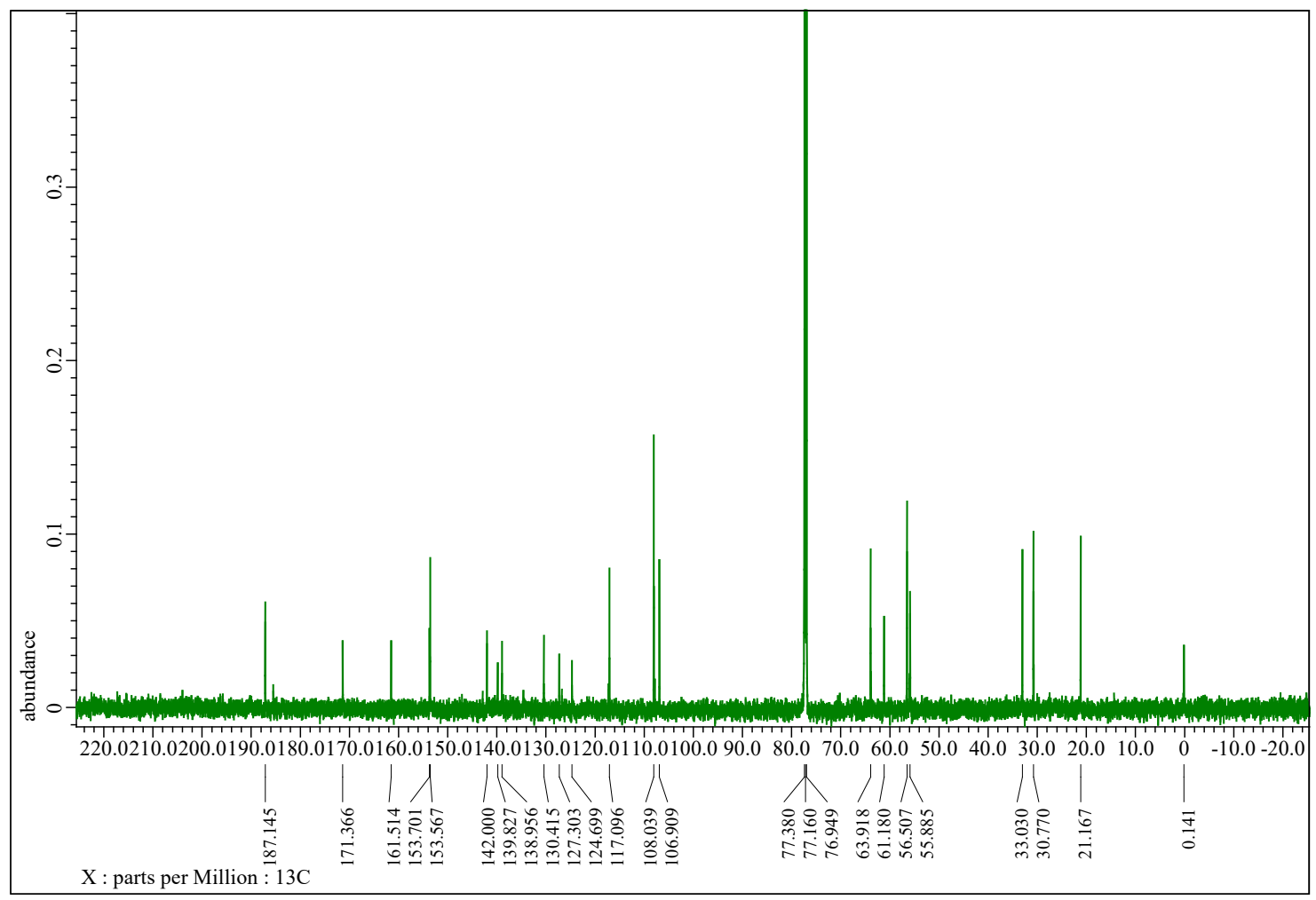


Figure S31. ${ }^{1} \mathrm{H}$ NMR spectrum of compound $21\left(600 \mathrm{MHz}\right.$, in $\left.\mathrm{CDCl}_{3}\right)$

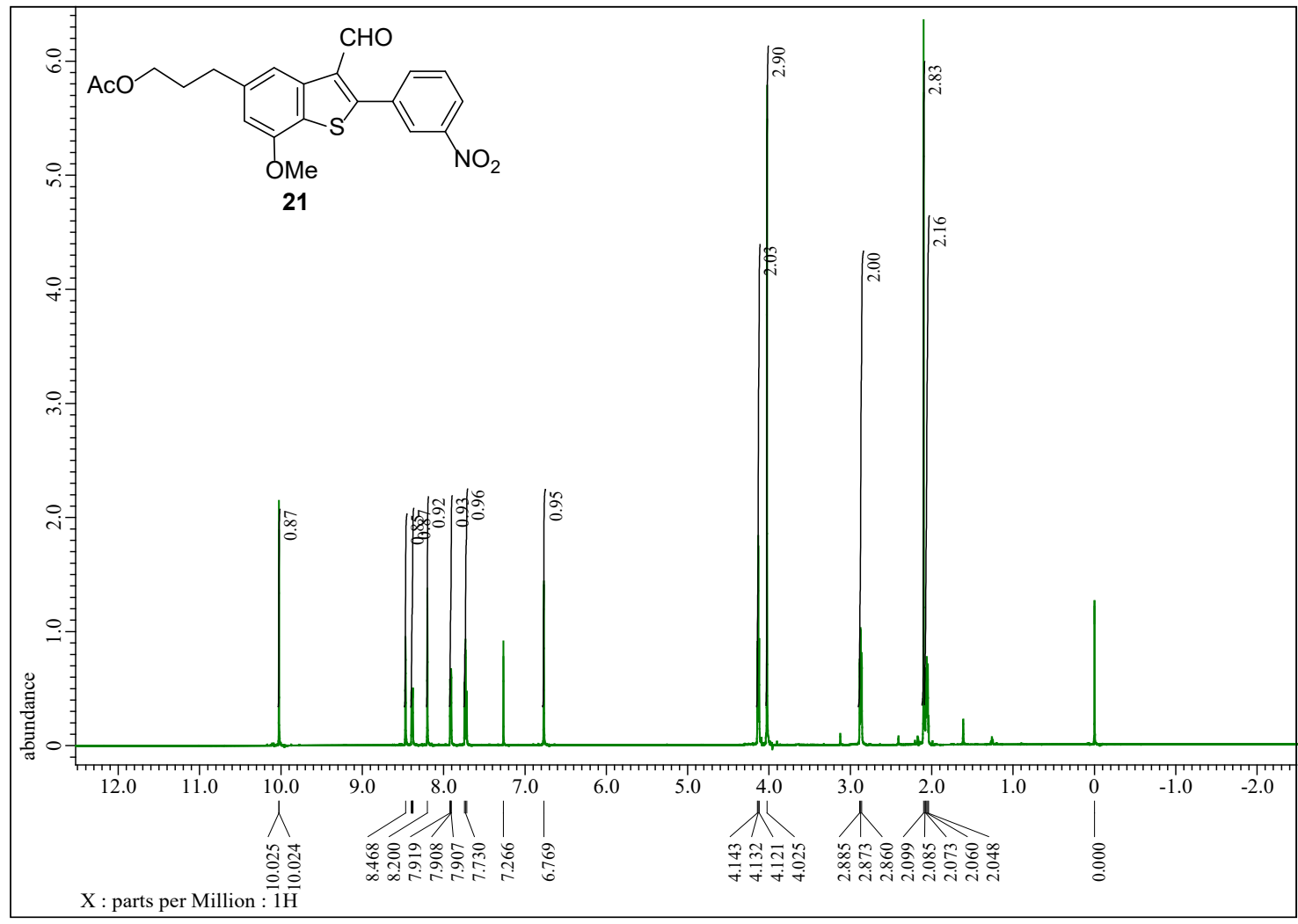

Figure S32. ${ }^{13} \mathrm{C}\left\{{ }^{1} \mathrm{H}\right\}$ NMR spectrum of compound $21\left(150 \mathrm{MHz}\right.$, in $\left.\mathrm{CDCl}_{3}\right)$

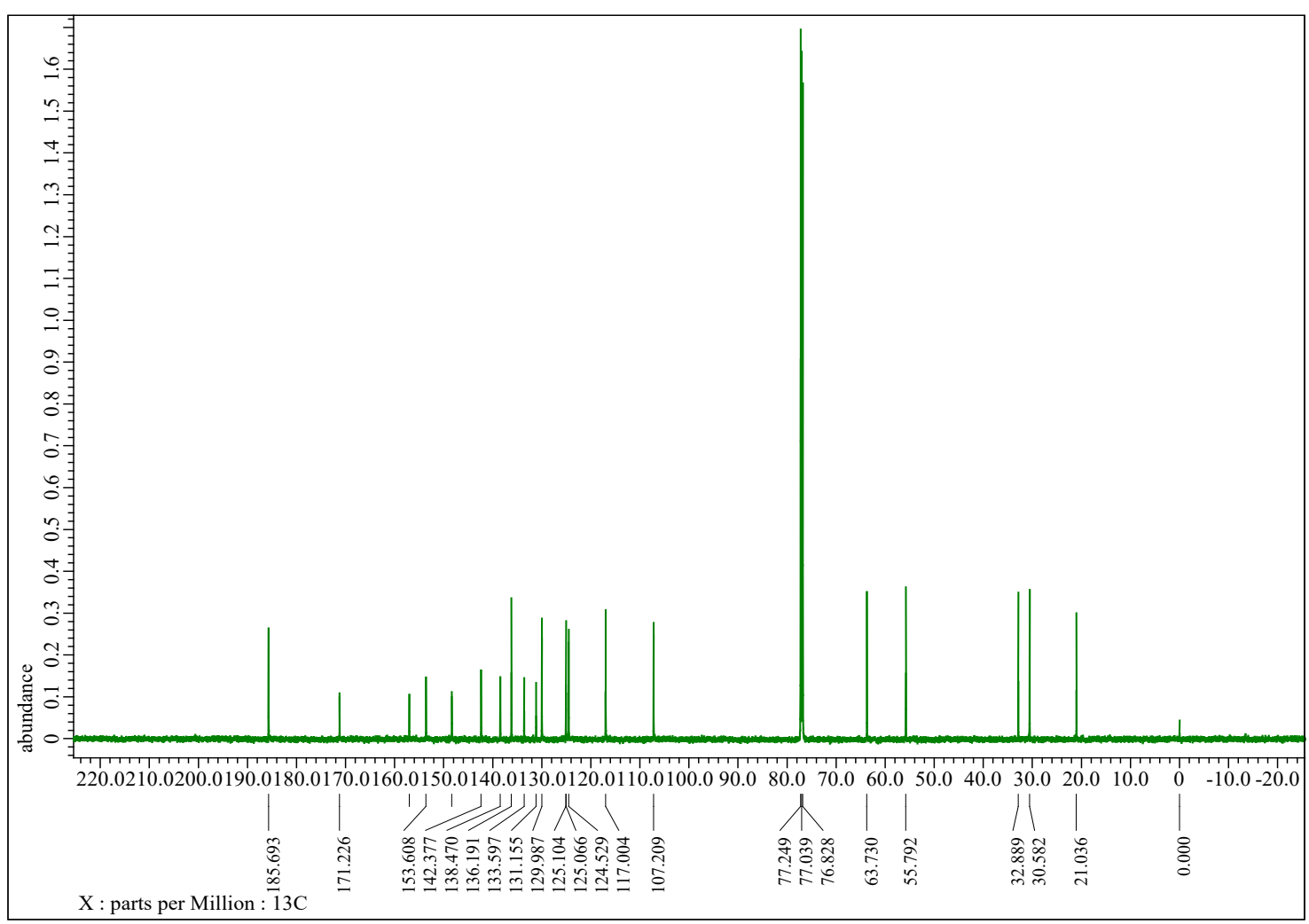


Figure S33. ${ }^{1} \mathrm{H}$ NMR spectrum of compound $22\left(600 \mathrm{MHz}\right.$, in $\left.\mathrm{CDCl}_{3}\right)$

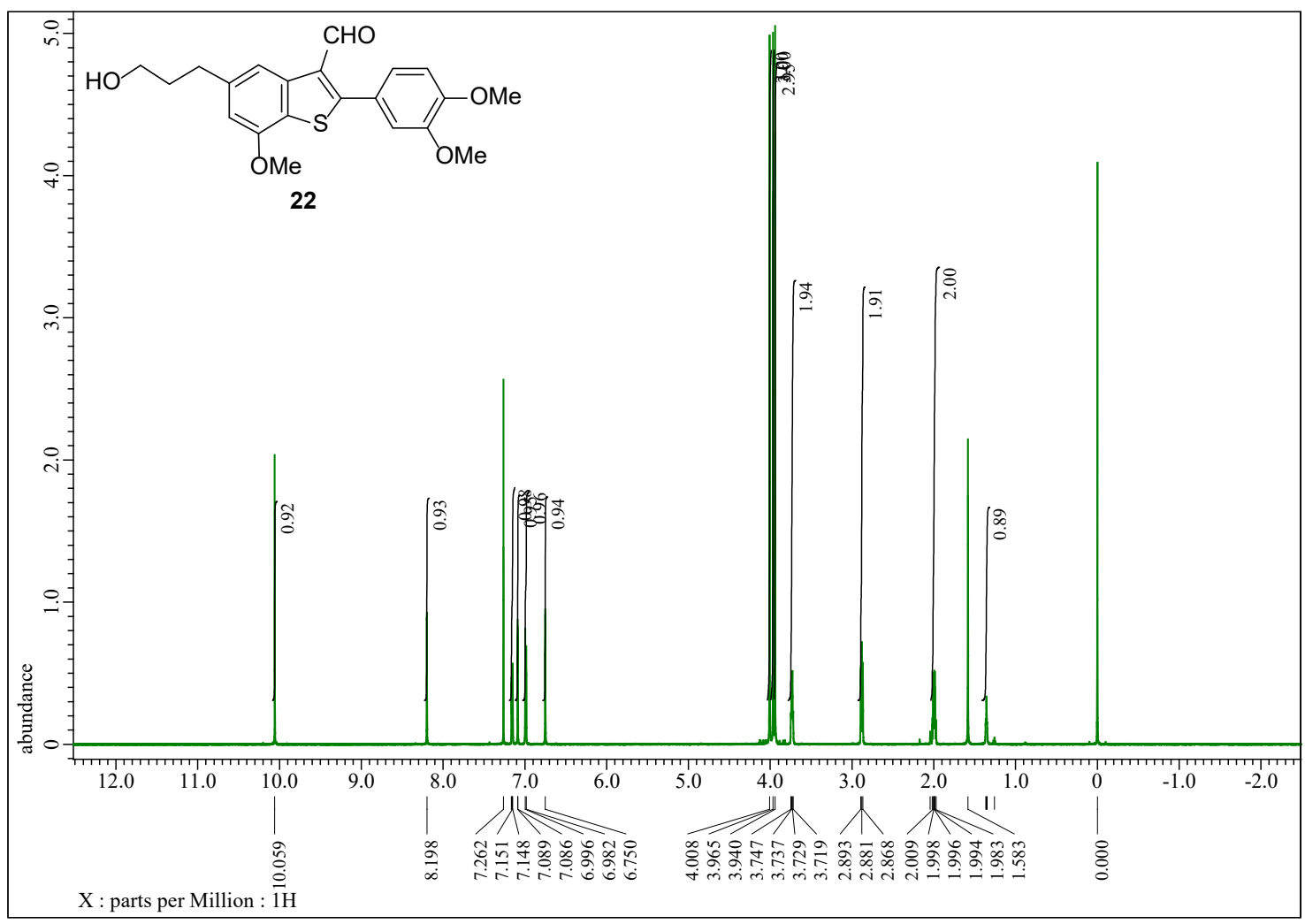

Figure S34. ${ }^{13} \mathrm{C}\left\{{ }^{1} \mathrm{H}\right\}$ NMR spectrum of compound $22\left(100 \mathrm{MHz}\right.$, in $\left.\mathrm{CDCl}_{3}\right)$

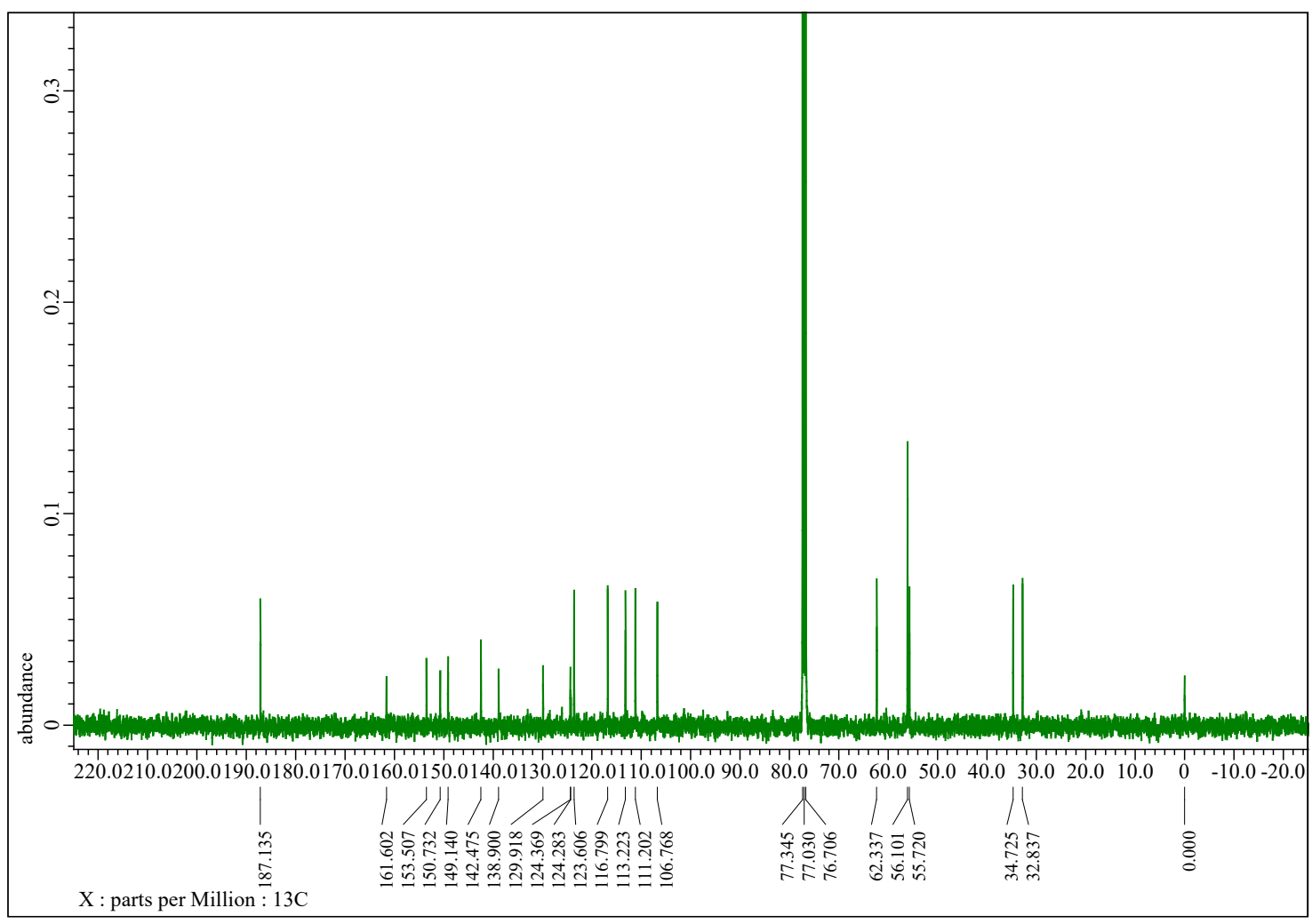


Figure S35. ${ }^{1} \mathrm{H}$ NMR spectrum of compound $23\left(400 \mathrm{MHz}\right.$, in $\left.\mathrm{CDCl}_{3}\right)$

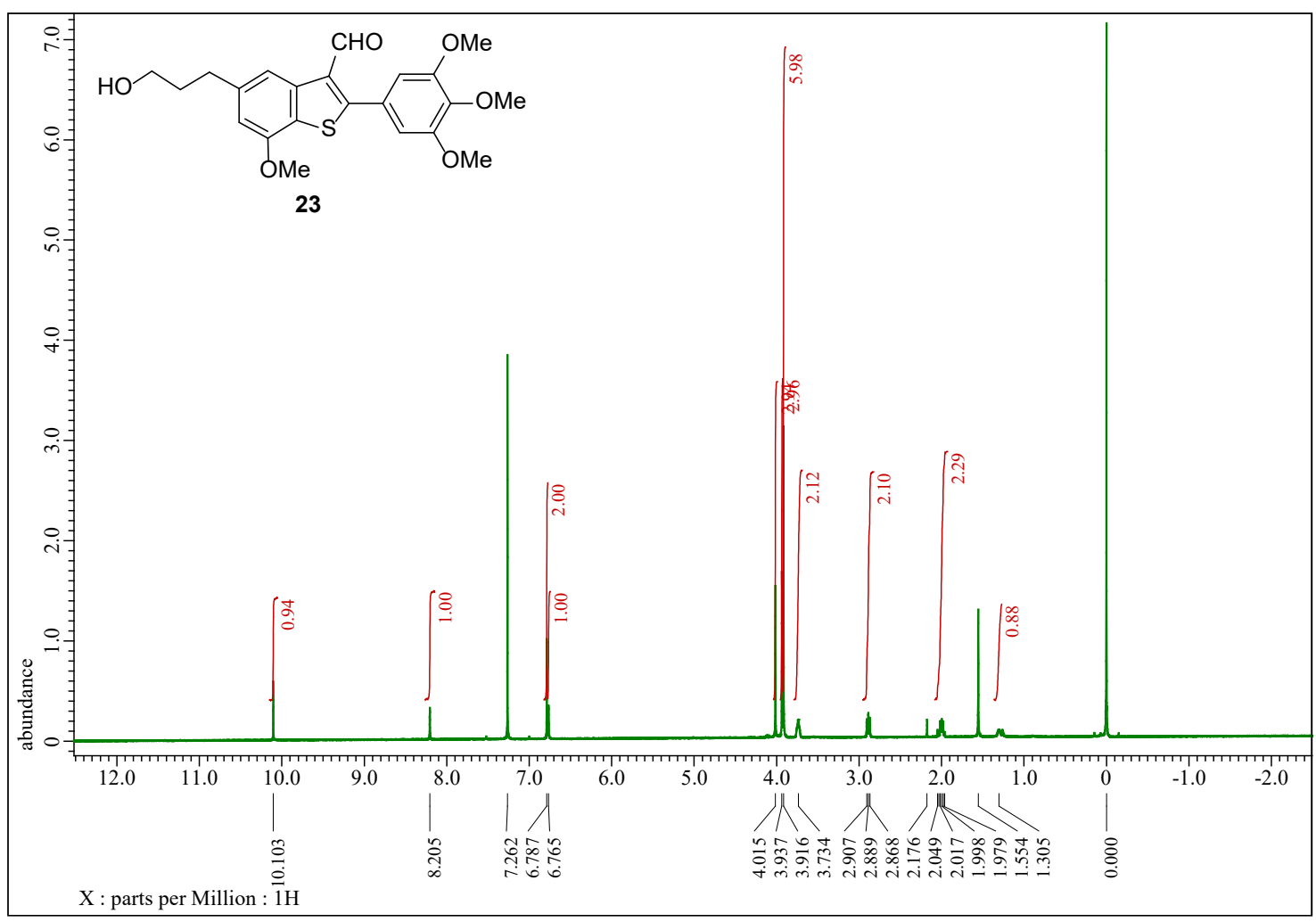

Figure S36. ${ }^{13} \mathrm{C}\left\{{ }^{1} \mathrm{H}\right\}$ NMR spectrum of compound $23\left(150 \mathrm{MHz}\right.$, in $\left.\mathrm{CDCl}_{3}\right)$

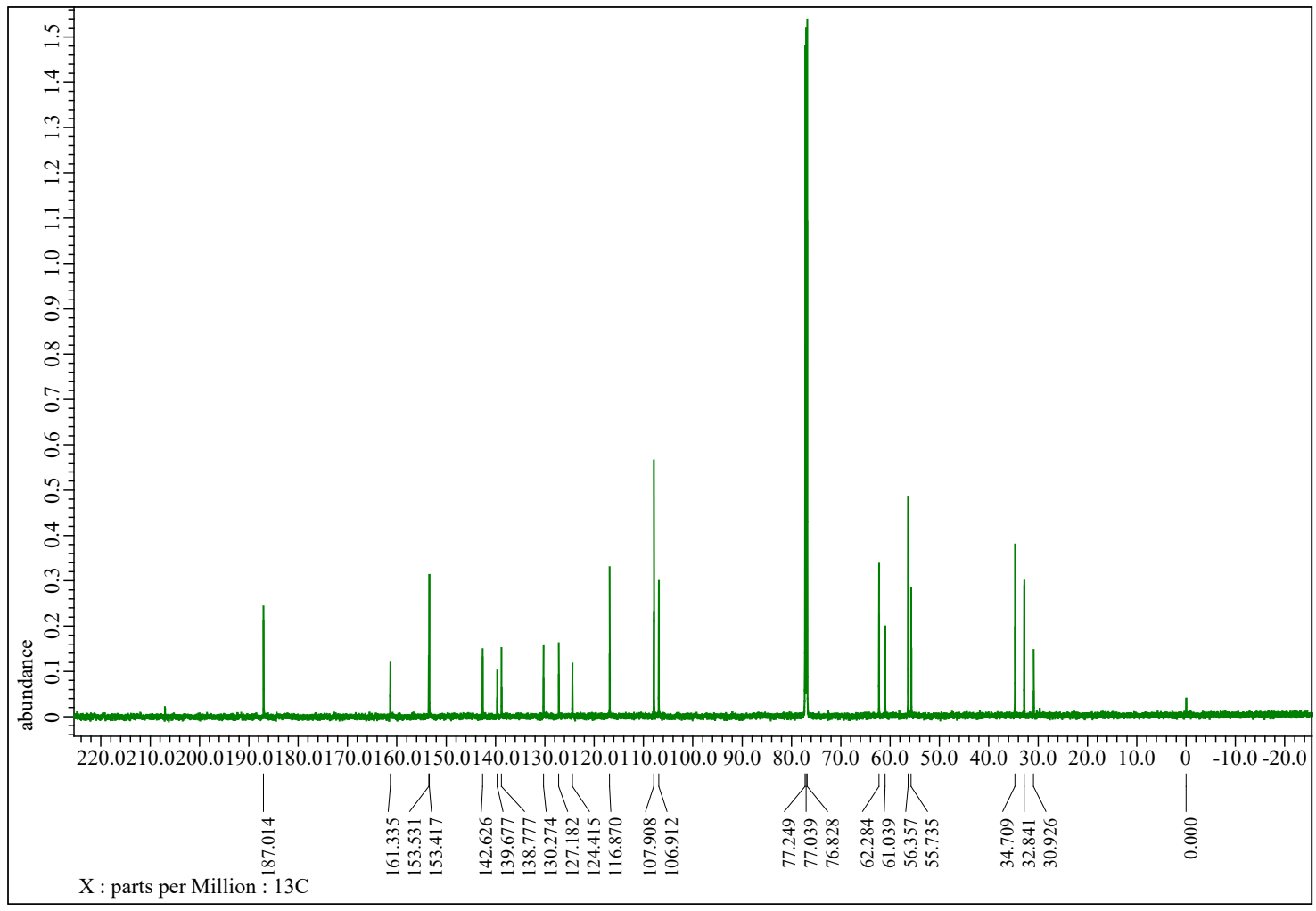


Figure S37. ${ }^{1} \mathrm{H}$ NMR spectrum of compound $24\left(600 \mathrm{MHz}\right.$, in $\left.\mathrm{CDCl}_{3}\right)$

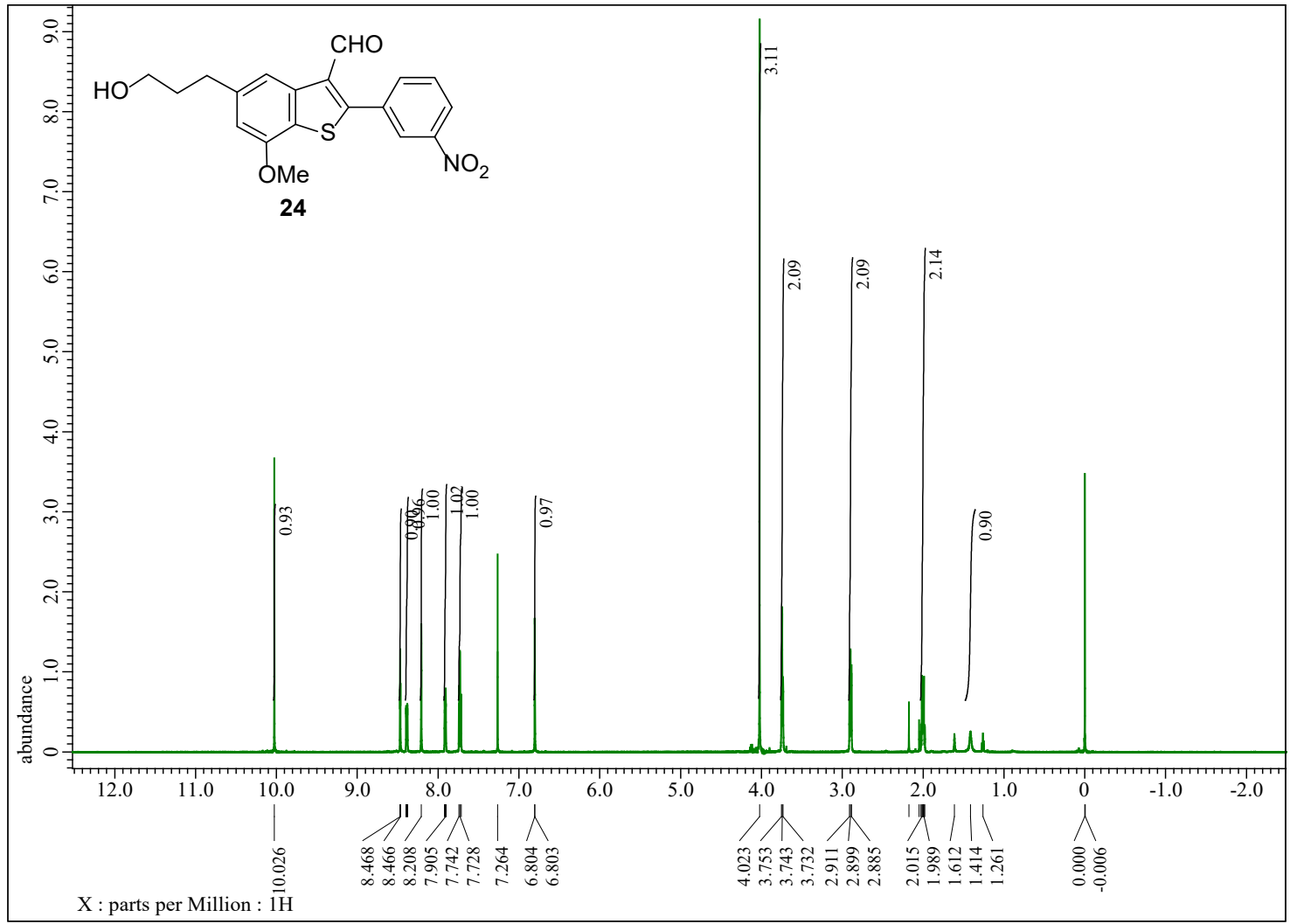

Figure S38. ${ }^{13} \mathrm{C}\left\{{ }^{1} \mathrm{H}\right\}$ NMR spectrum of compound $24\left(150 \mathrm{MHz}\right.$, in $\left.\mathrm{CDCl}_{3}\right)$

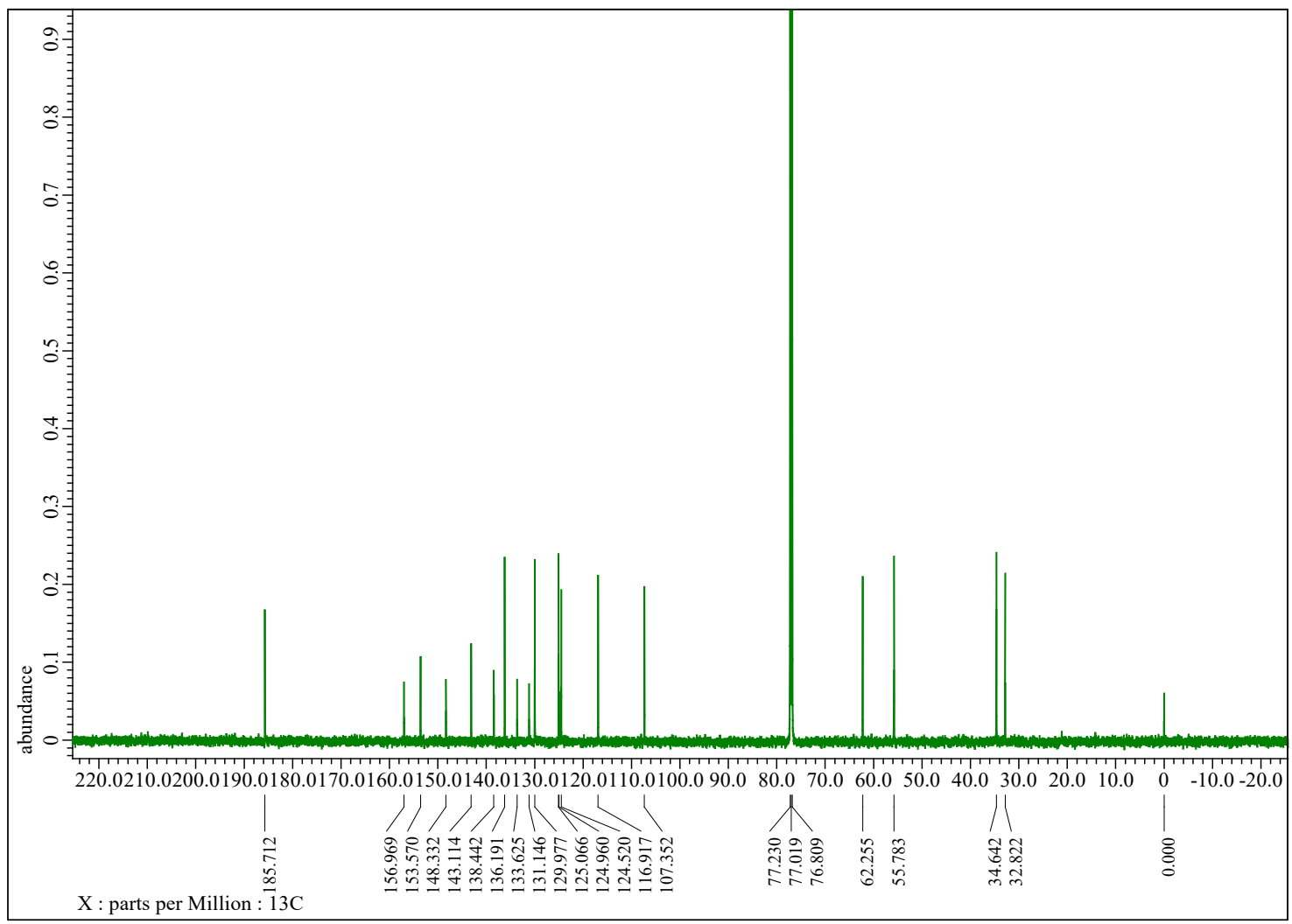


Figure S39. ${ }^{1} \mathrm{H}$ NMR spectrum of compound $28\left(400 \mathrm{MHz}\right.$, in $\left.\mathrm{CDCl}_{3}\right)$

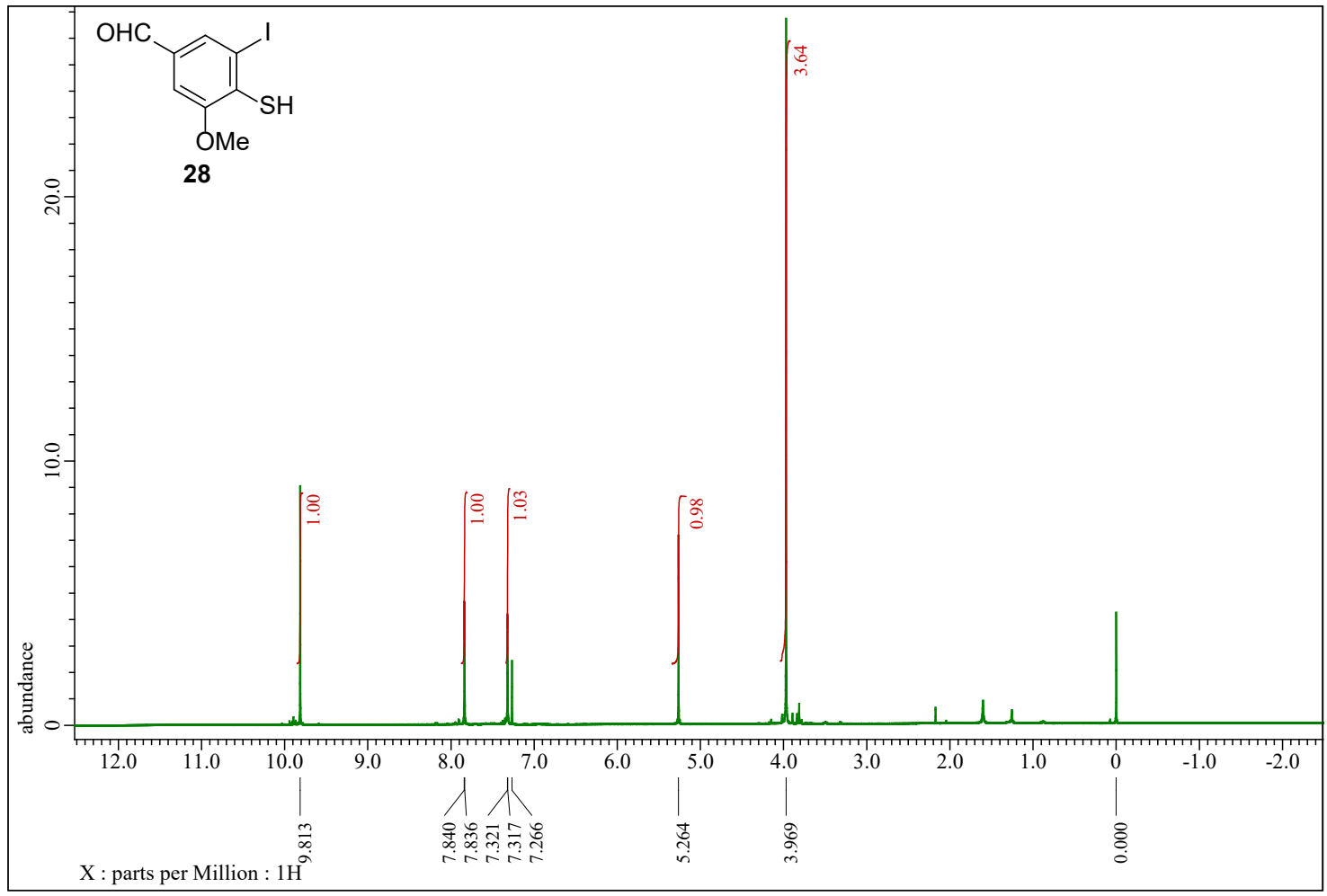

Figure S40. ${ }^{13} \mathrm{C}\left\{{ }^{1} \mathrm{H}\right\}$ NMR spectrum of compound $28\left(100 \mathrm{MHz}\right.$, in $\left.\mathrm{CDCl}_{3}\right)$

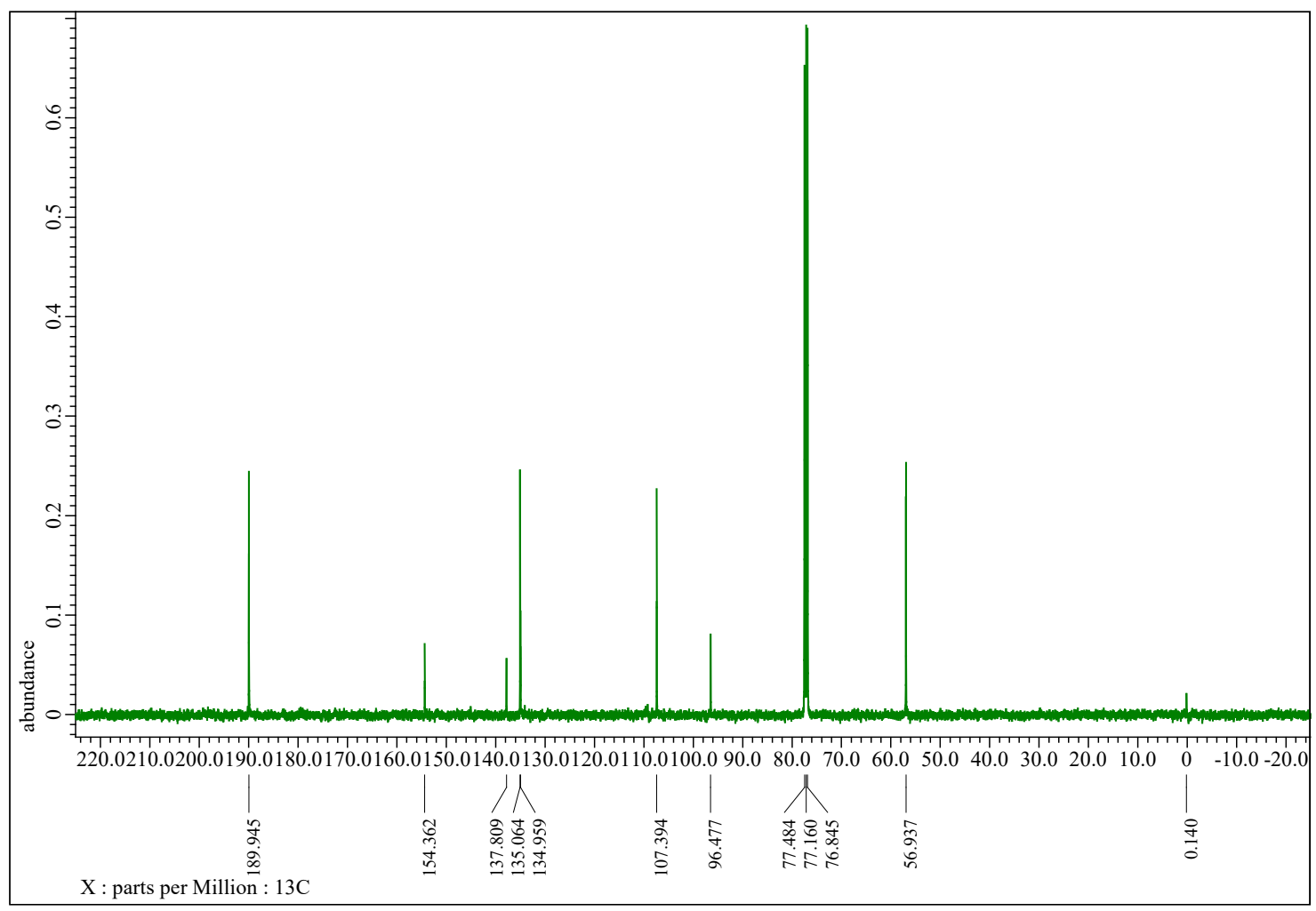


Figure S41. ${ }^{1} \mathrm{H}$ NMR spectrum of compound $29\left(600 \mathrm{MHz}\right.$, in $\left.\mathrm{CDCl}_{3}\right)$

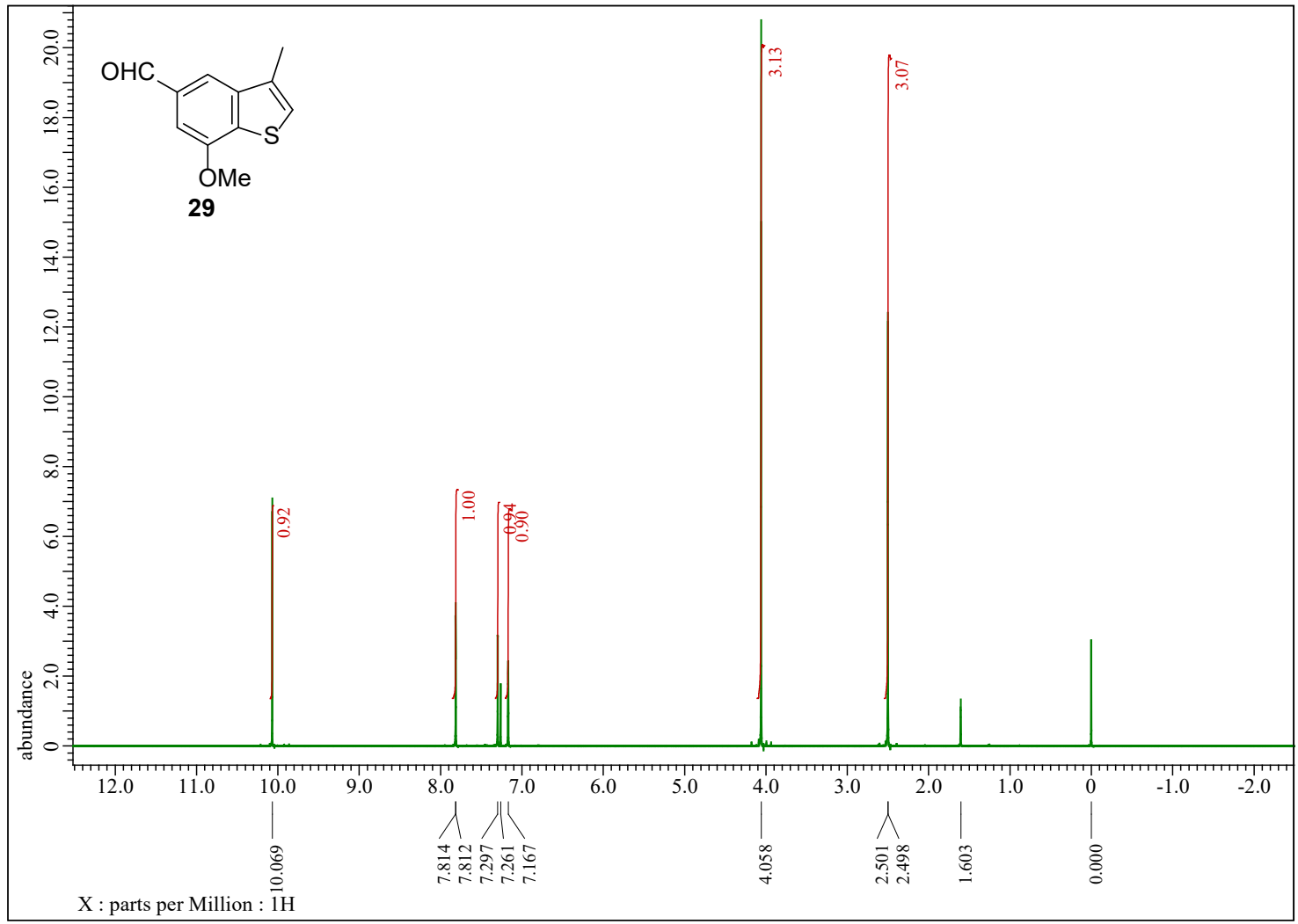

Figure S42. ${ }^{13} \mathrm{C}\left\{{ }^{1} \mathrm{H}\right\}$ NMR spectrum of compound $29\left(150 \mathrm{MHz}\right.$, in $\left.\mathrm{CDCl}_{3}\right)$

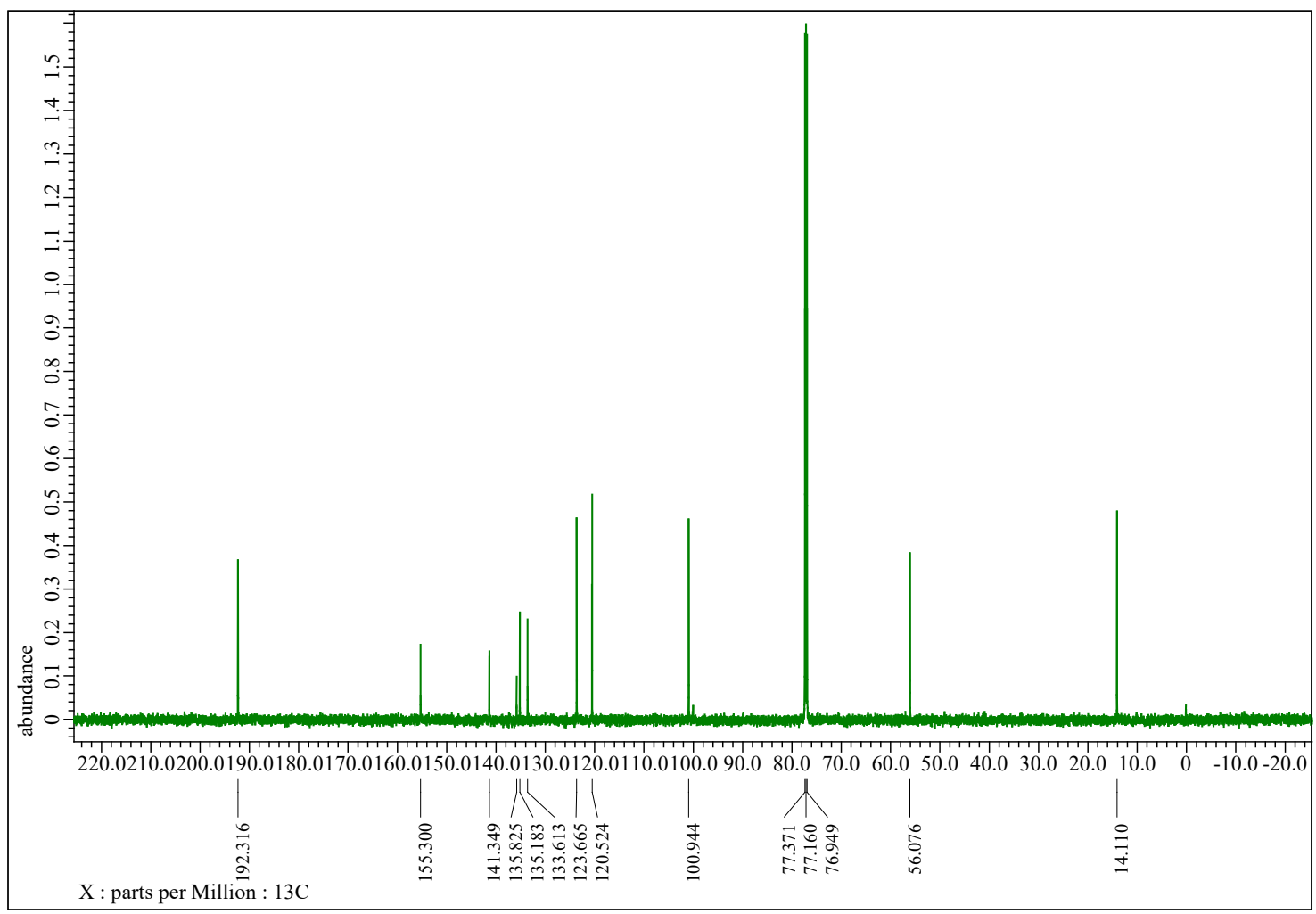


Figure S43. ${ }^{1} \mathrm{H}$ NMR spectrum of compound $30\left(600 \mathrm{MHz}\right.$, in $\left.\mathrm{CDCl}_{3}\right)$

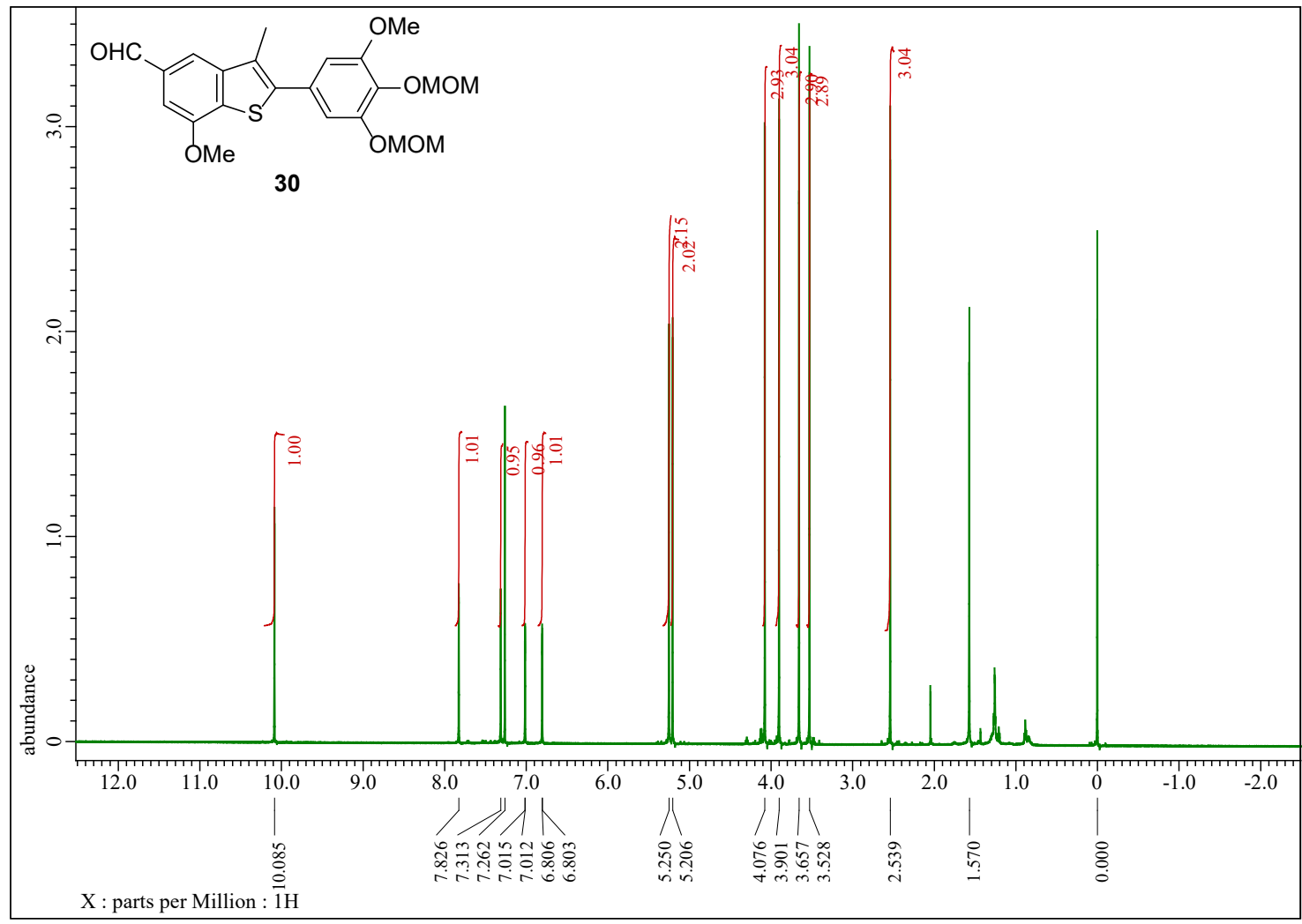

Figure S44. ${ }^{13} \mathrm{C}\left\{{ }^{1} \mathrm{H}\right\}$ NMR spectrum of compound $30\left(150 \mathrm{MHz}\right.$, in $\left.\mathrm{CDCl}_{3}\right)$

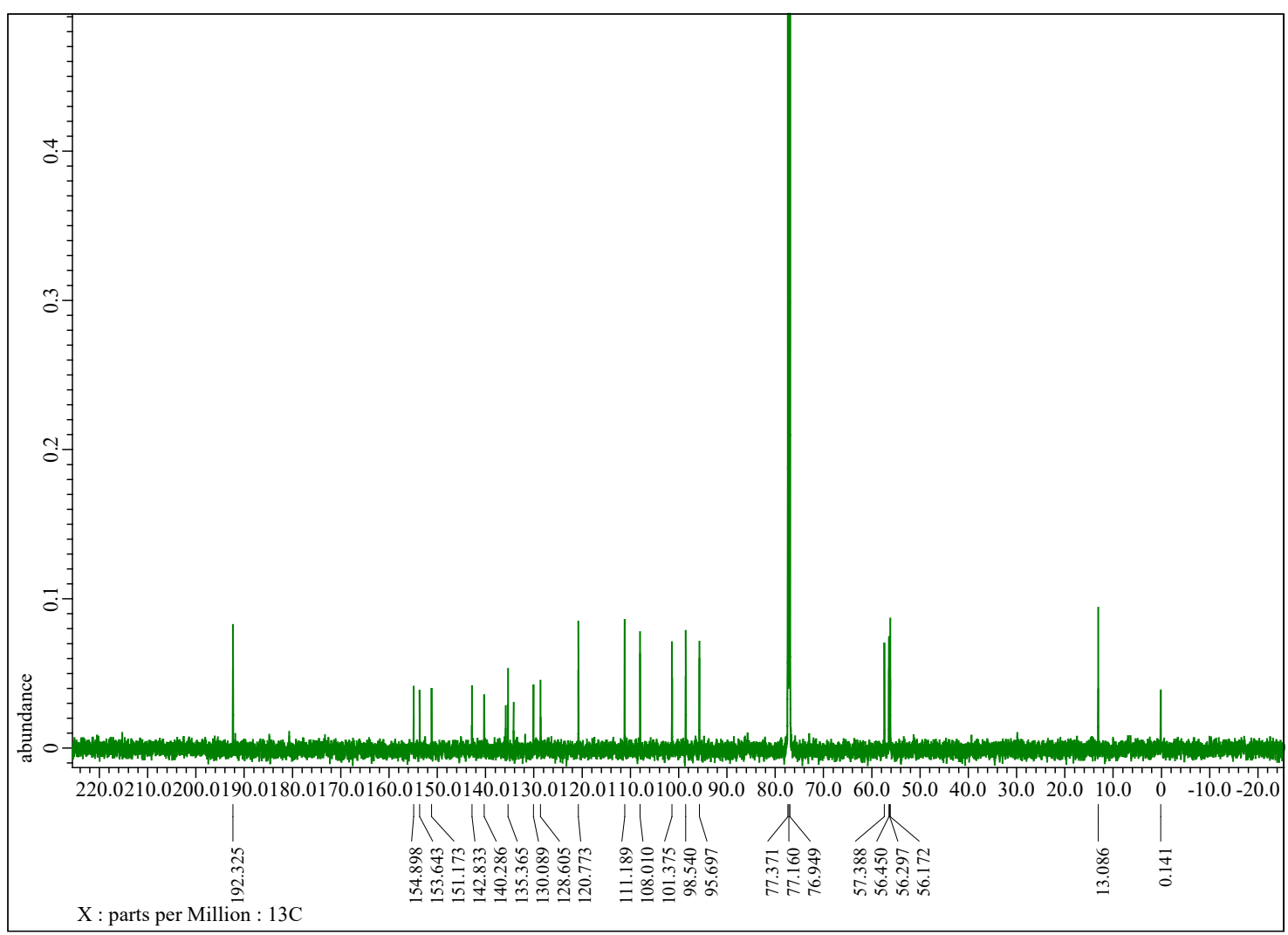


Figure S45. ${ }^{1} \mathrm{H}$ NMR spectrum of compound $31\left(400 \mathrm{MHz}\right.$, in $\left.\mathrm{CDCl}_{3}\right)$

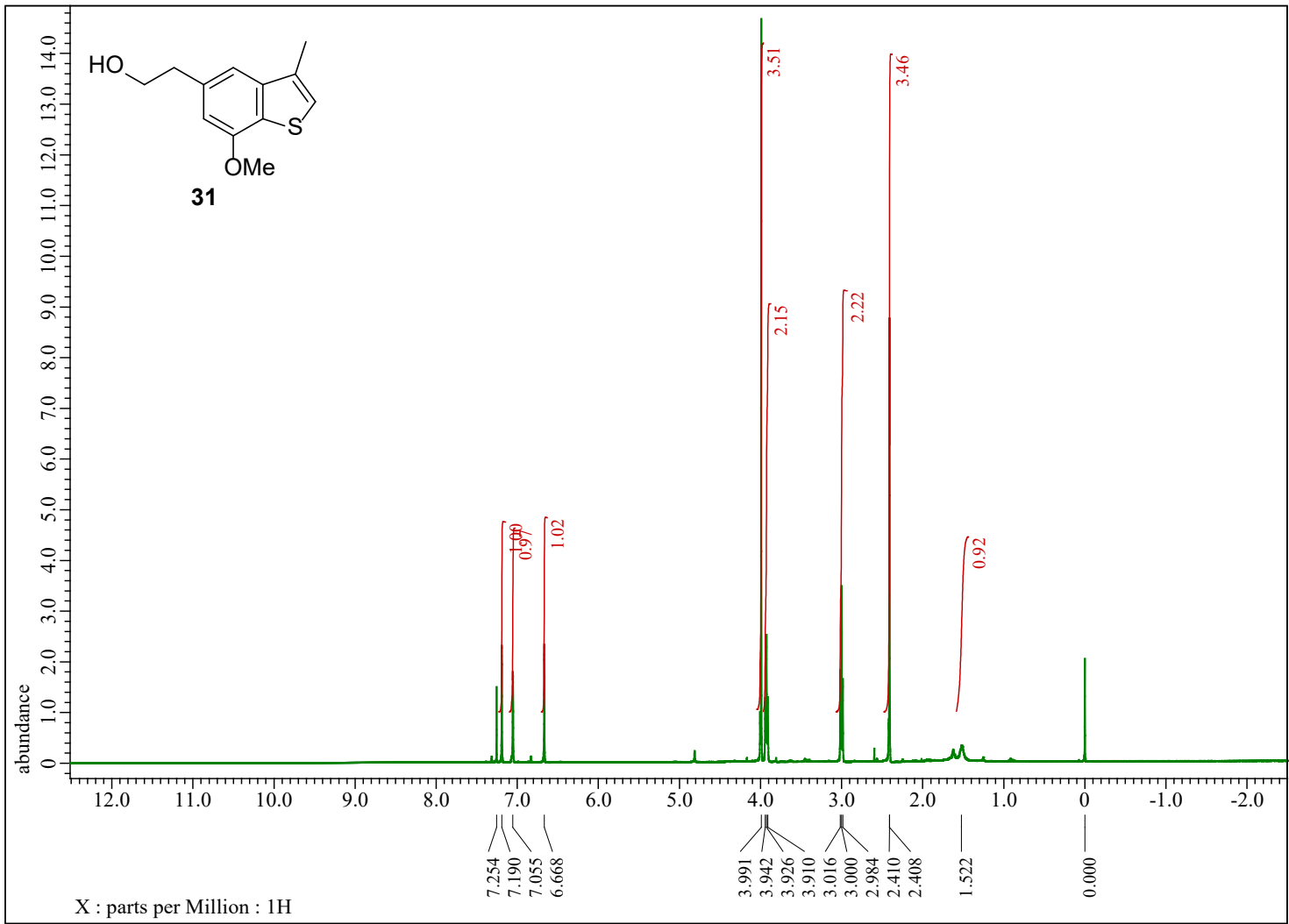

Figure S46. ${ }^{13} \mathrm{C}\left\{{ }^{1} \mathrm{H}\right\}$ NMR spectrum of compound $31\left(150 \mathrm{MHz}\right.$, in $\left.\mathrm{CDCl}_{3}\right)$

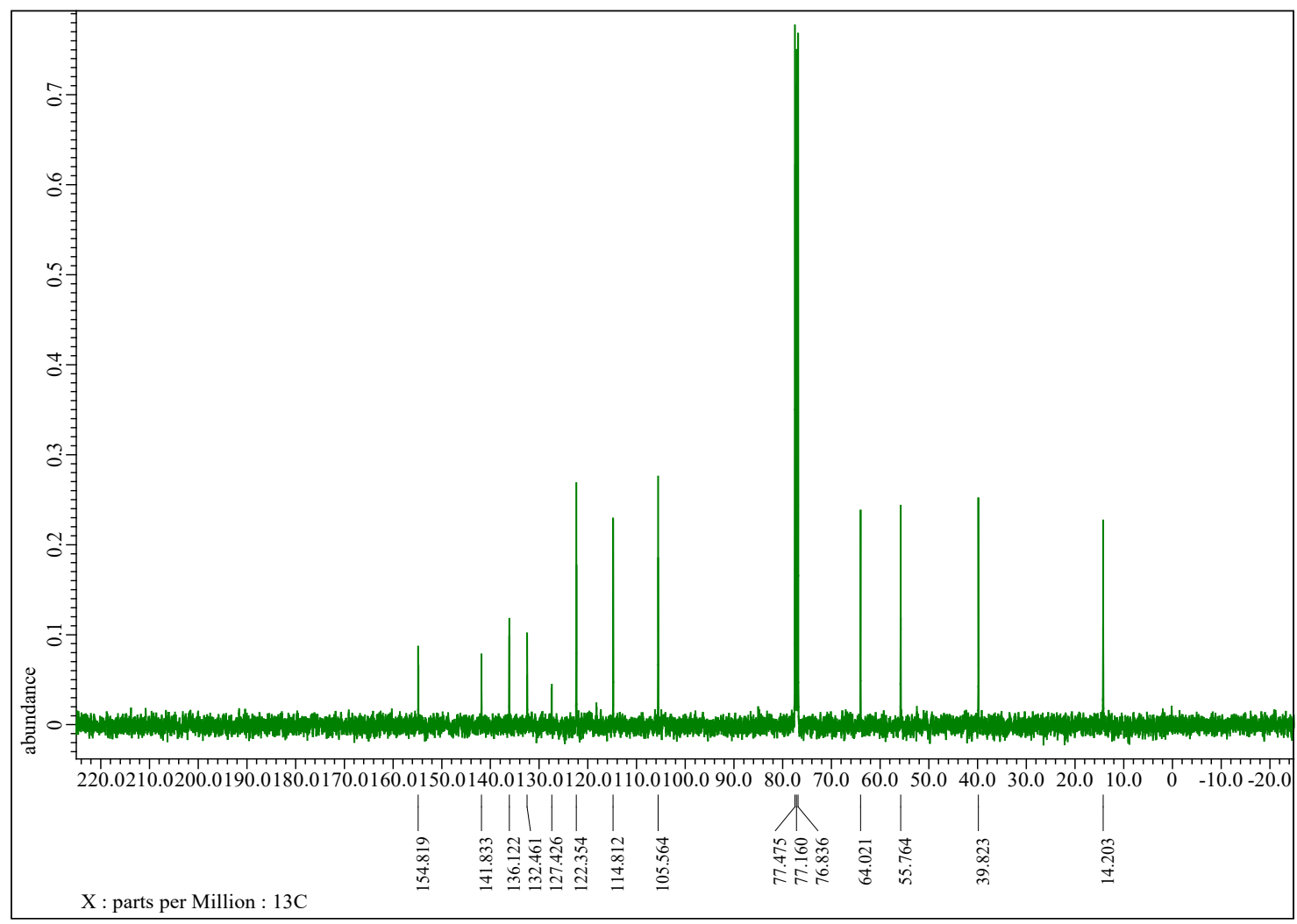


Figure S47. ${ }^{1} \mathrm{H}$ NMR spectrum of compound $32\left(400 \mathrm{MHz}\right.$, in $\left.\mathrm{CDCl}_{3}\right)$

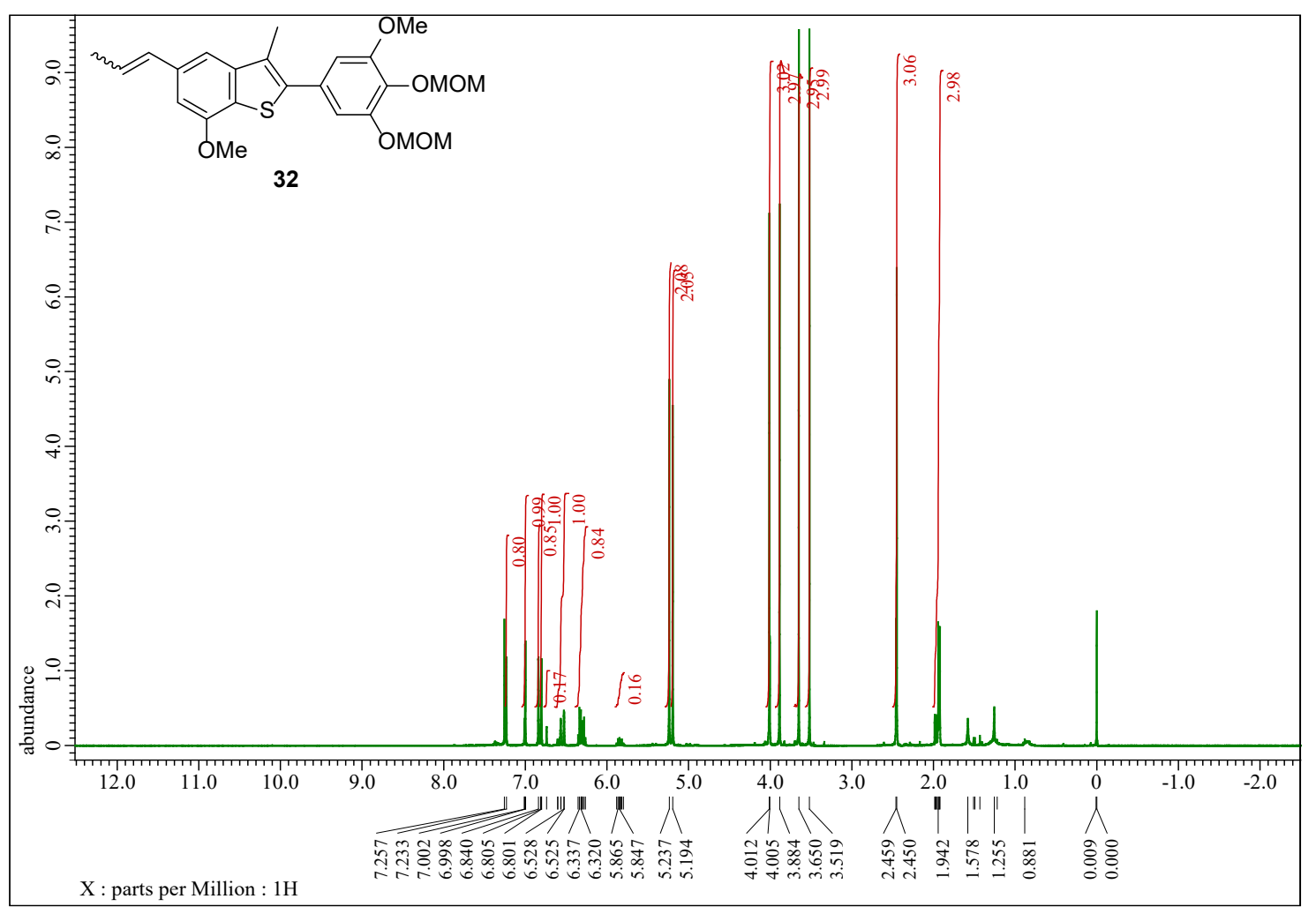

Figure S48. ${ }^{13} \mathrm{C}\left\{{ }^{1} \mathrm{H}\right\}$ NMR spectrum of compound $32\left(100 \mathrm{MHz}\right.$, in $\left.\mathrm{CDCl}_{3}\right)$

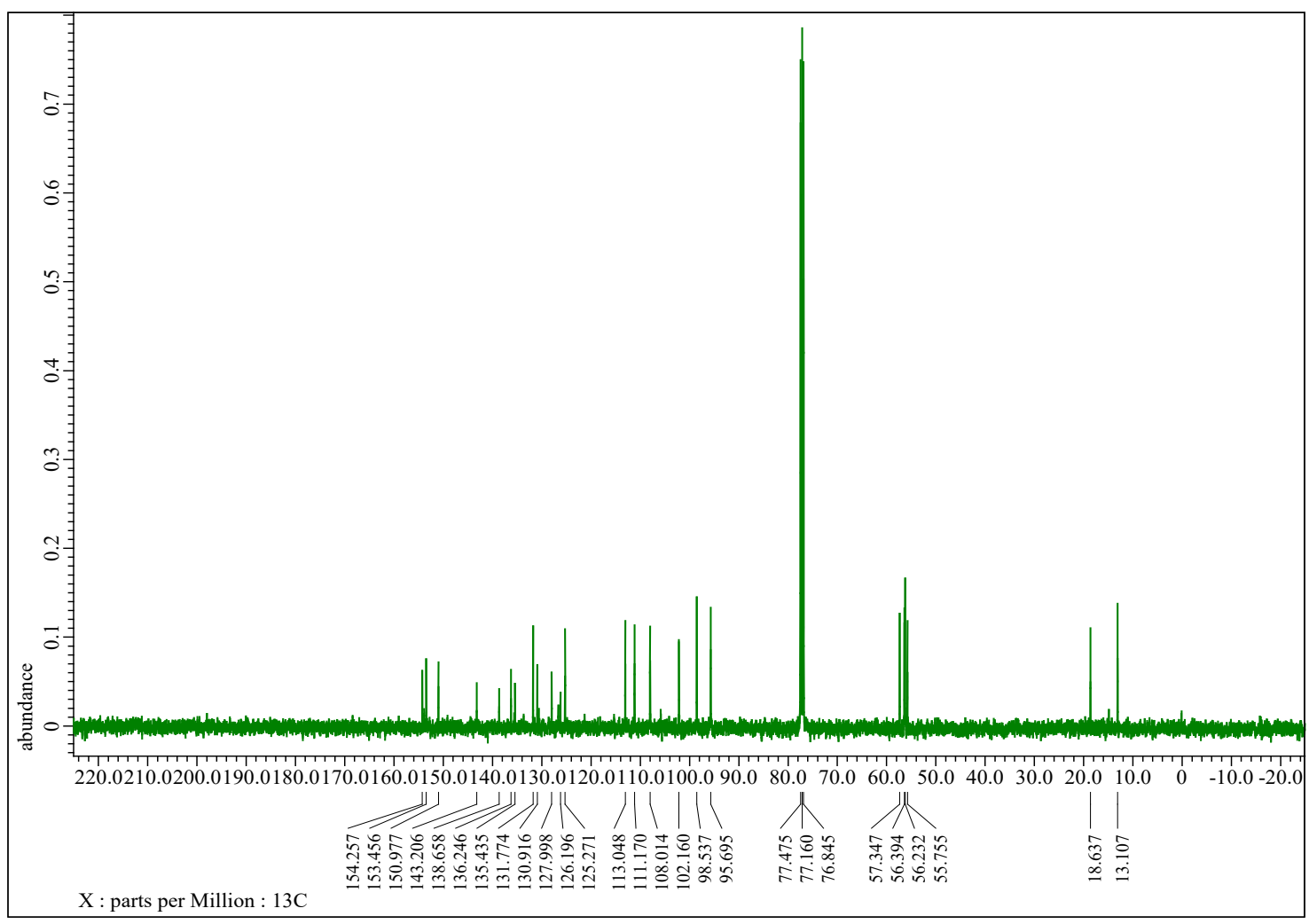


Figure S49. ${ }^{1} \mathrm{H}$ NMR spectrum of compound $33\left(600 \mathrm{MHz}\right.$, in $\left.\mathrm{CDCl}_{3}\right)$

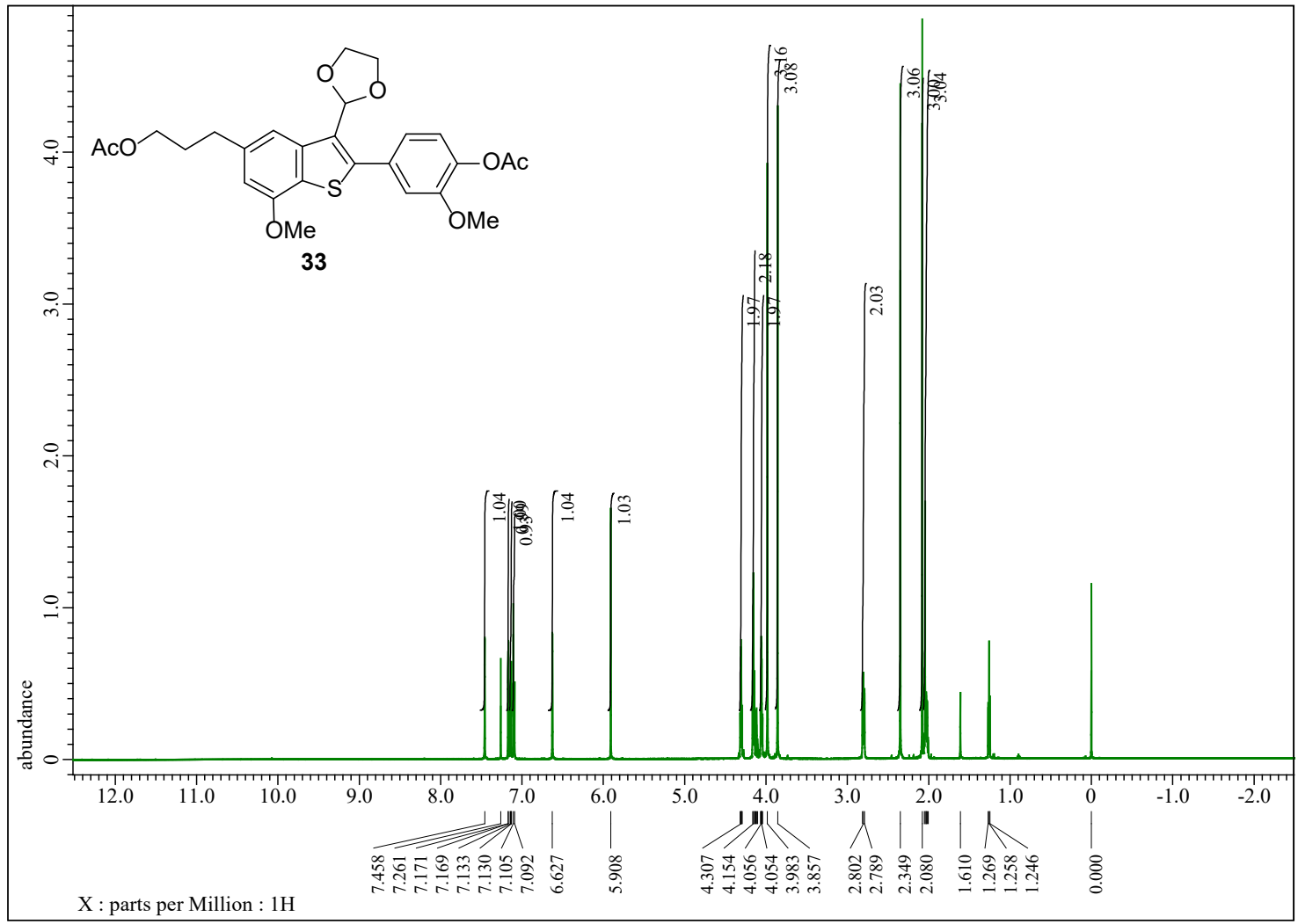

Figure S50. ${ }^{13} \mathrm{C}\left\{{ }^{1} \mathrm{H}\right\}$ NMR spectrum of compound $33\left(150 \mathrm{MHz}\right.$, in $\left.\mathrm{CDCl}_{3}\right)$

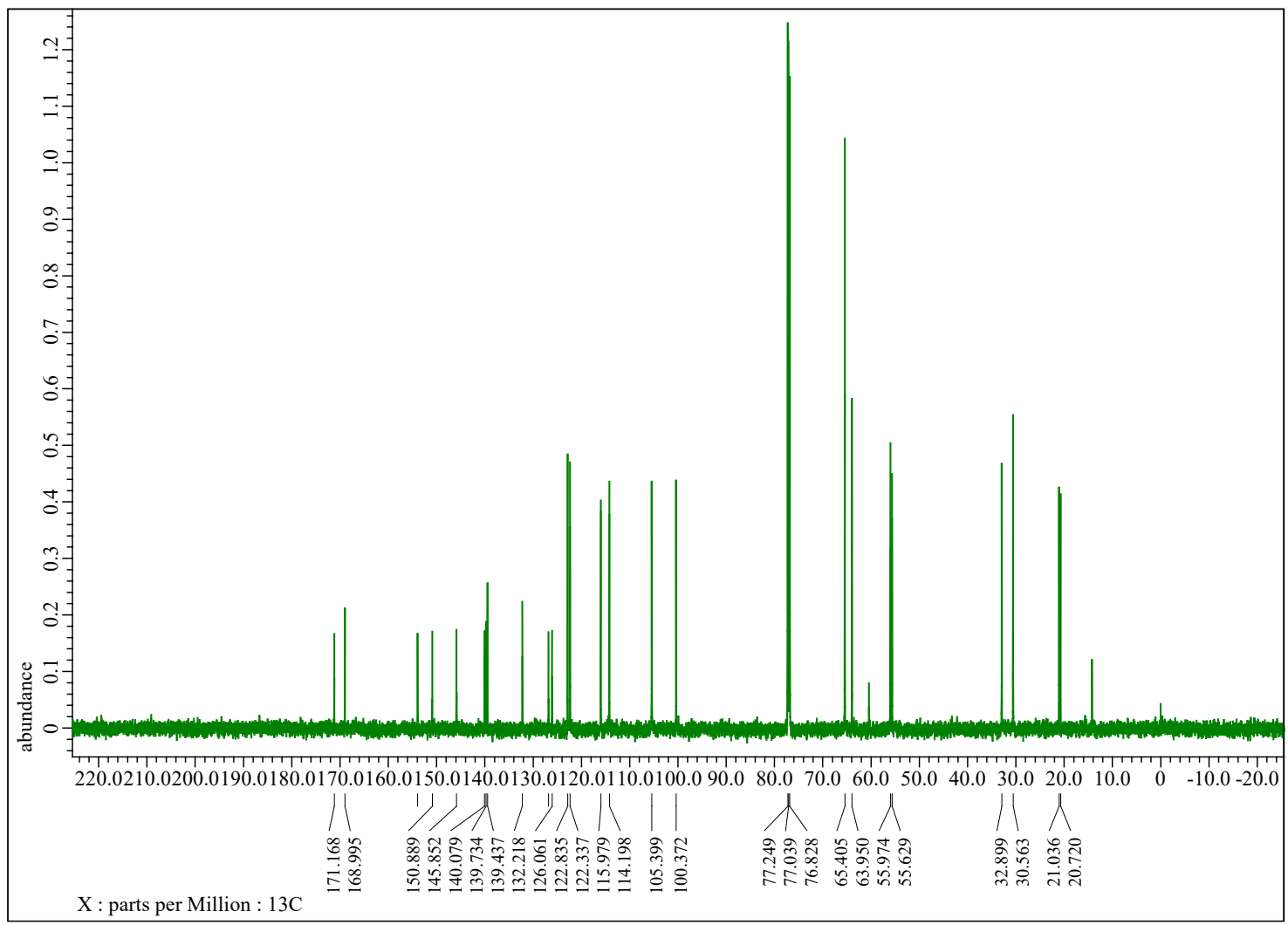


Figure S51. ${ }^{1} \mathrm{H}$ NMR spectrum of compound $34\left(600 \mathrm{MHz}\right.$, in $\left.\mathrm{CDCl}_{3}\right)$

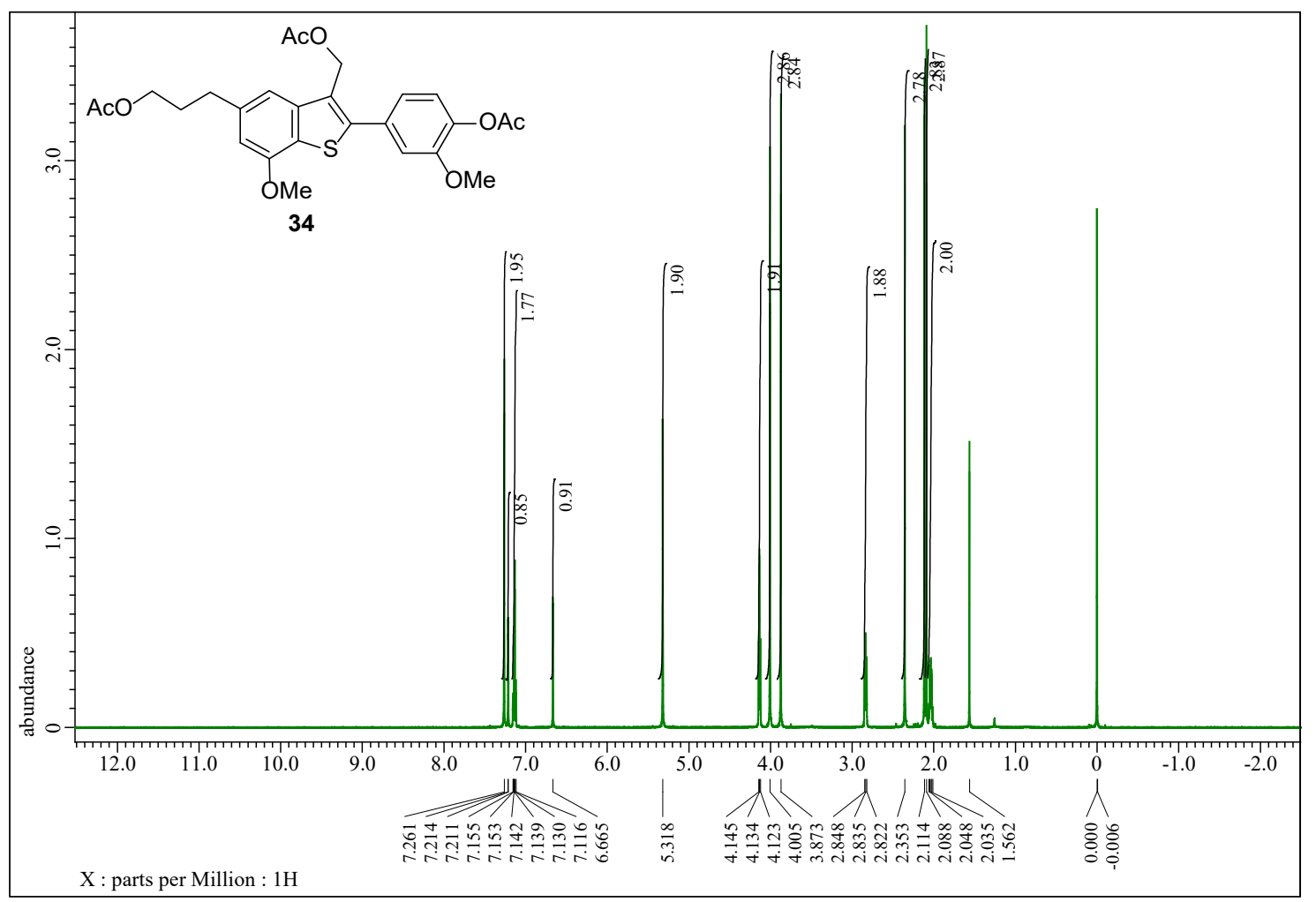

Figure S52. ${ }^{13} \mathrm{C}\left\{{ }^{1} \mathrm{H}\right\}$ NMR spectrum of compound $34\left(150 \mathrm{MHz}\right.$, in $\left.\mathrm{CDCl}_{3}\right)$

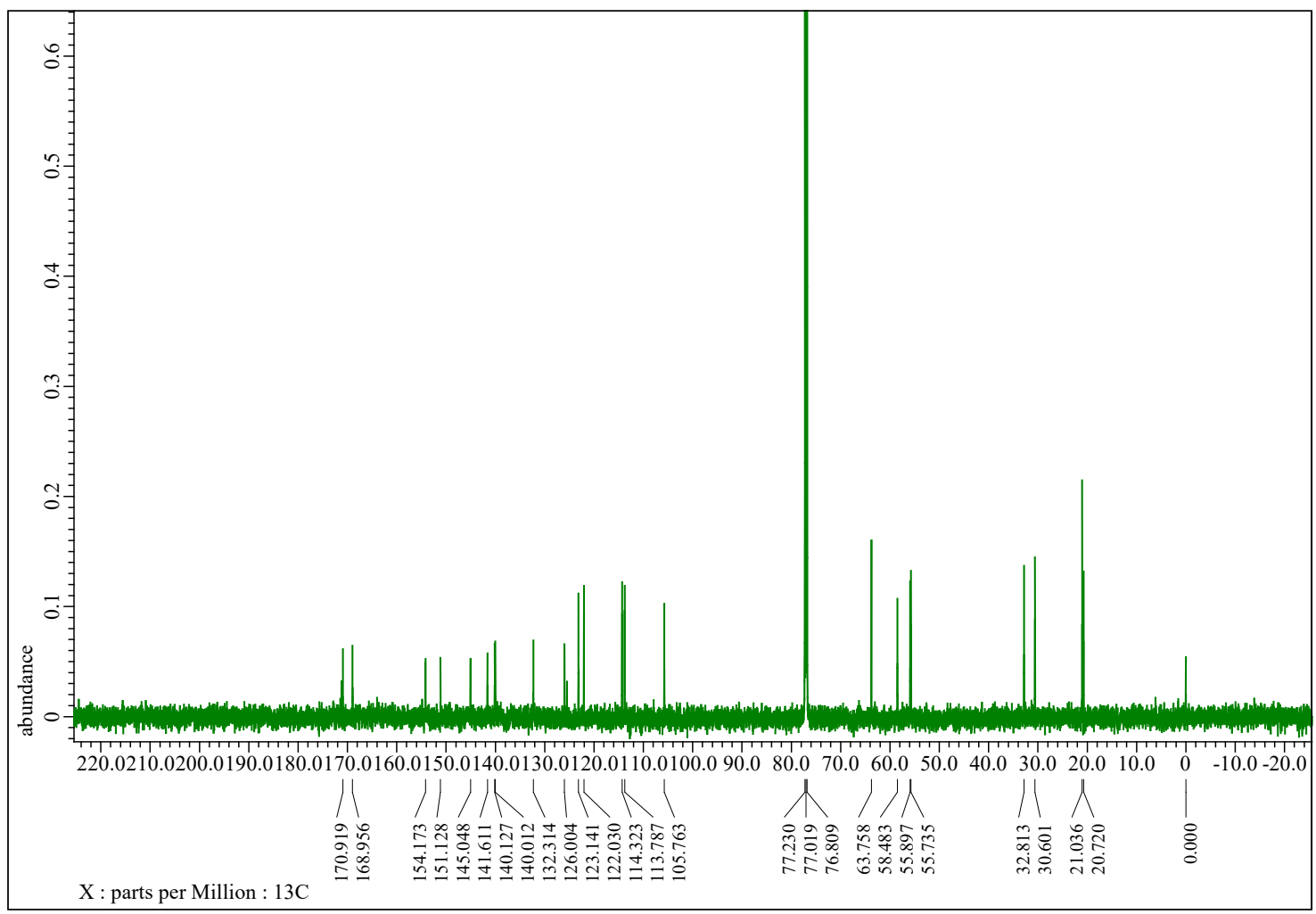


Figure S53. ${ }^{1} \mathrm{H}$ NMR spectrum of compound $35\left(600 \mathrm{MHz}\right.$, in $\left.\mathrm{CDCl}_{3}\right)$

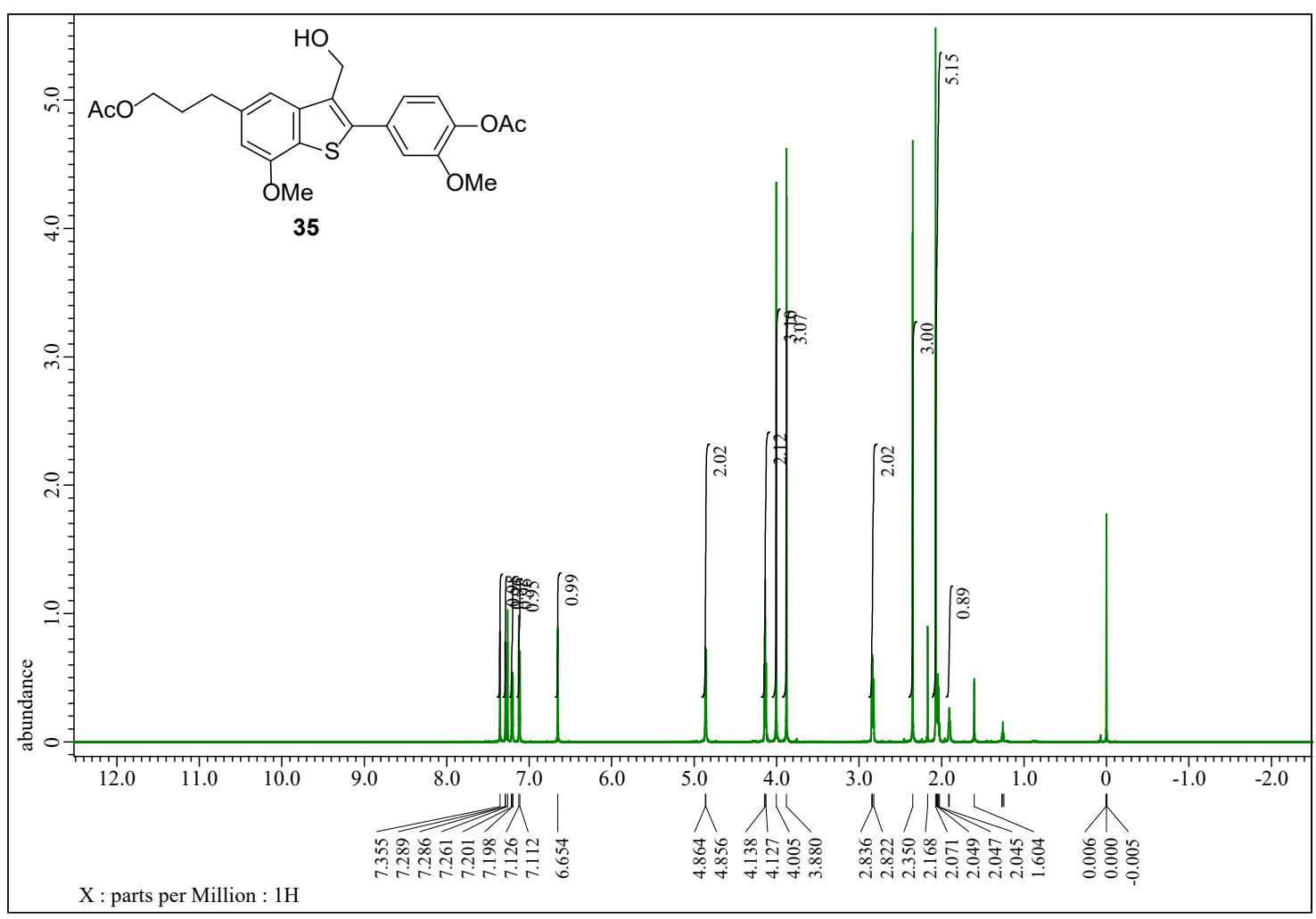

Figure S54. ${ }^{13} \mathrm{C}\left\{{ }^{1} \mathrm{H}\right\}$ NMR spectrum of compound $35\left(150 \mathrm{MHz}\right.$, in $\left.\mathrm{CDCl}_{3}\right)$

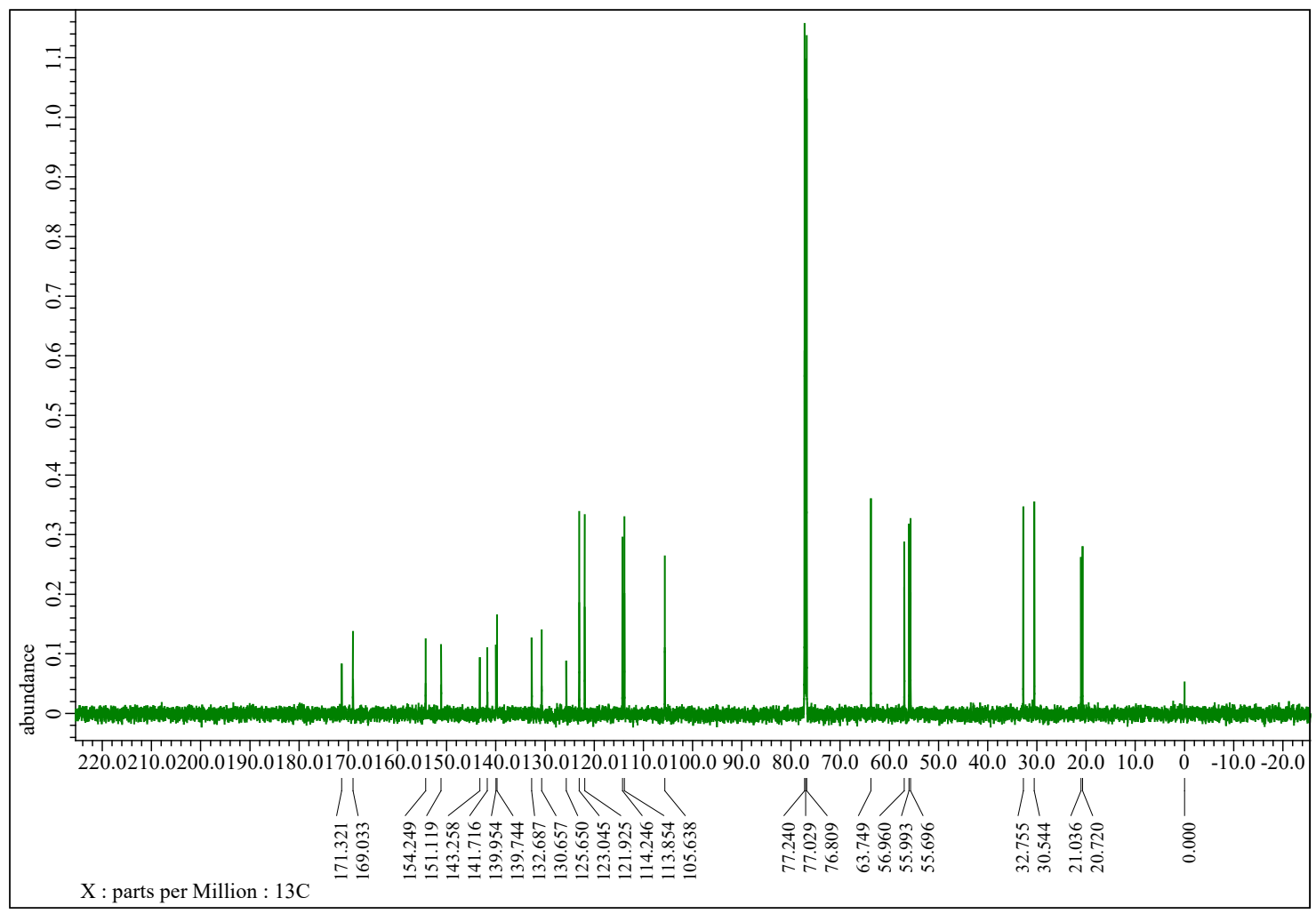


Figure S55. ${ }^{1} \mathrm{H}$ NMR spectrum of compound $36\left(400 \mathrm{MHz}\right.$, in DMSO- $\left.d_{6}\right)$

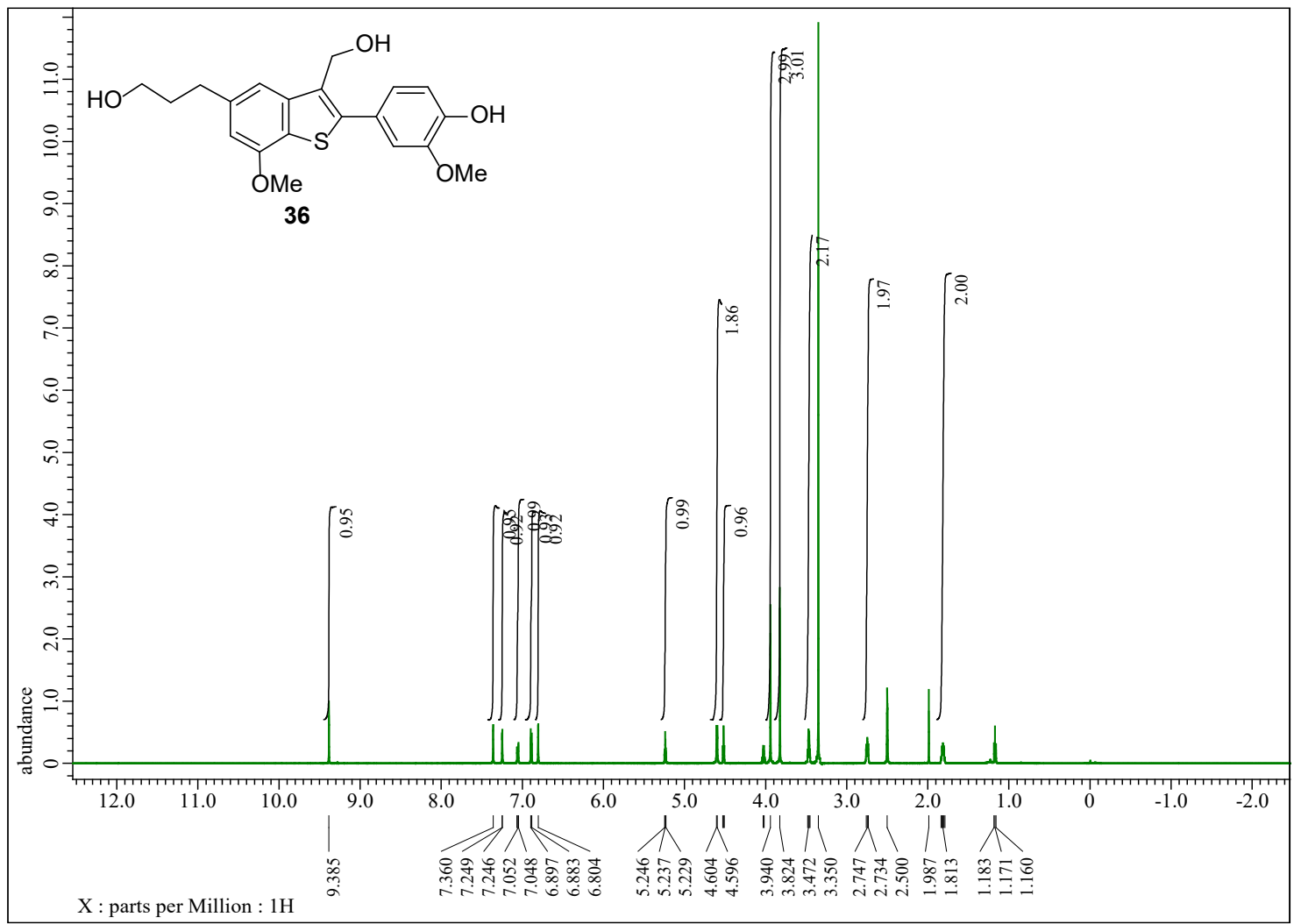

Figure S56. ${ }^{13} \mathrm{C}\left\{{ }^{1} \mathrm{H}\right\}$ NMR spectrum of compound $36\left(150 \mathrm{MHz}\right.$, in DMSO- $\left.d_{6}\right)$

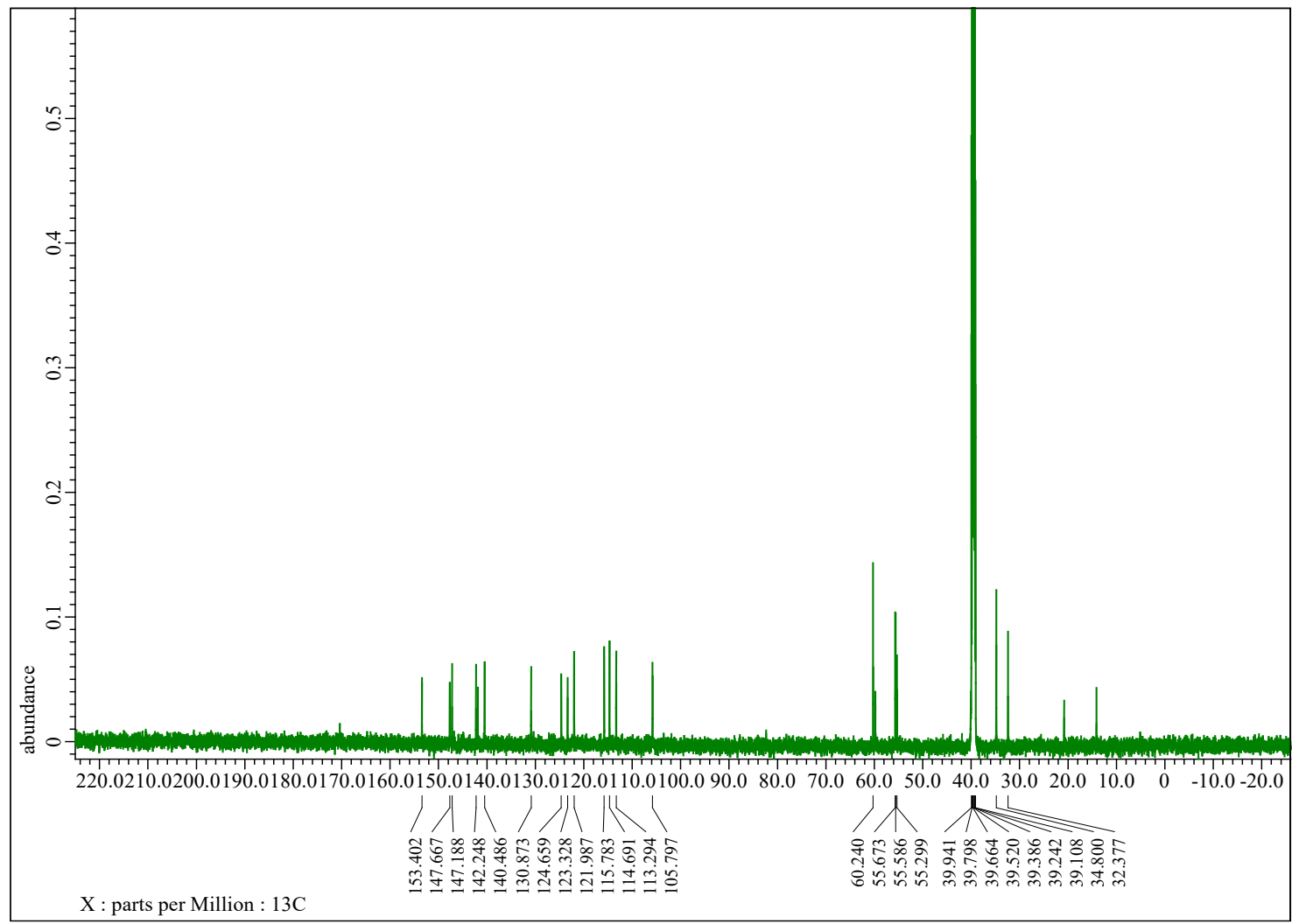


Figure S57. ${ }^{1} \mathrm{H}$ NMR spectrum of compound $37\left(600 \mathrm{MHz}\right.$, in $\left.\mathrm{CDCl}_{3}\right)$

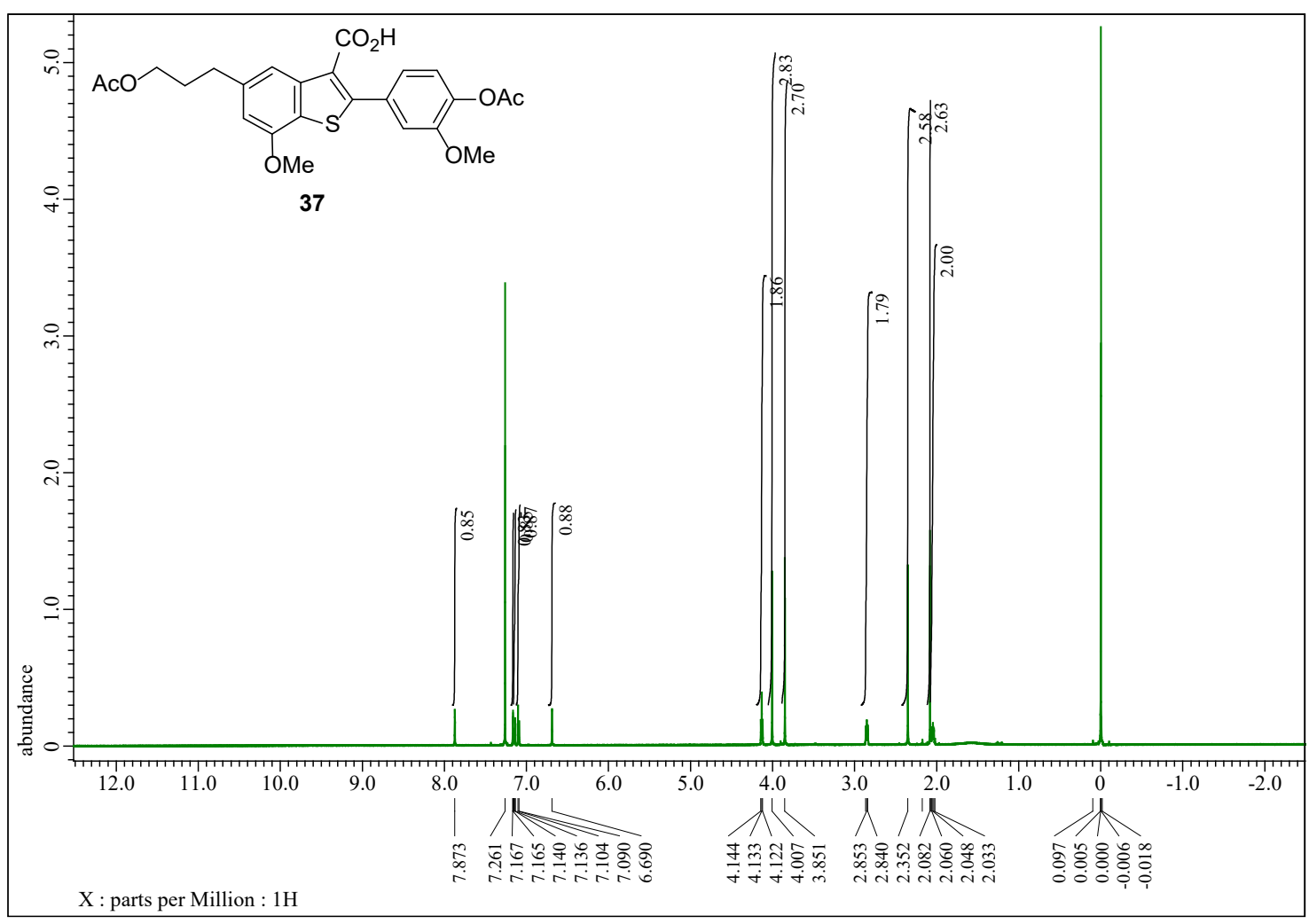

Figure S58. ${ }^{13} \mathrm{C}\left\{{ }^{1} \mathrm{H}\right\}$ NMR spectrum of compound $37\left(150 \mathrm{MHz}\right.$, in $\left.\mathrm{CDCl}_{3}\right)$

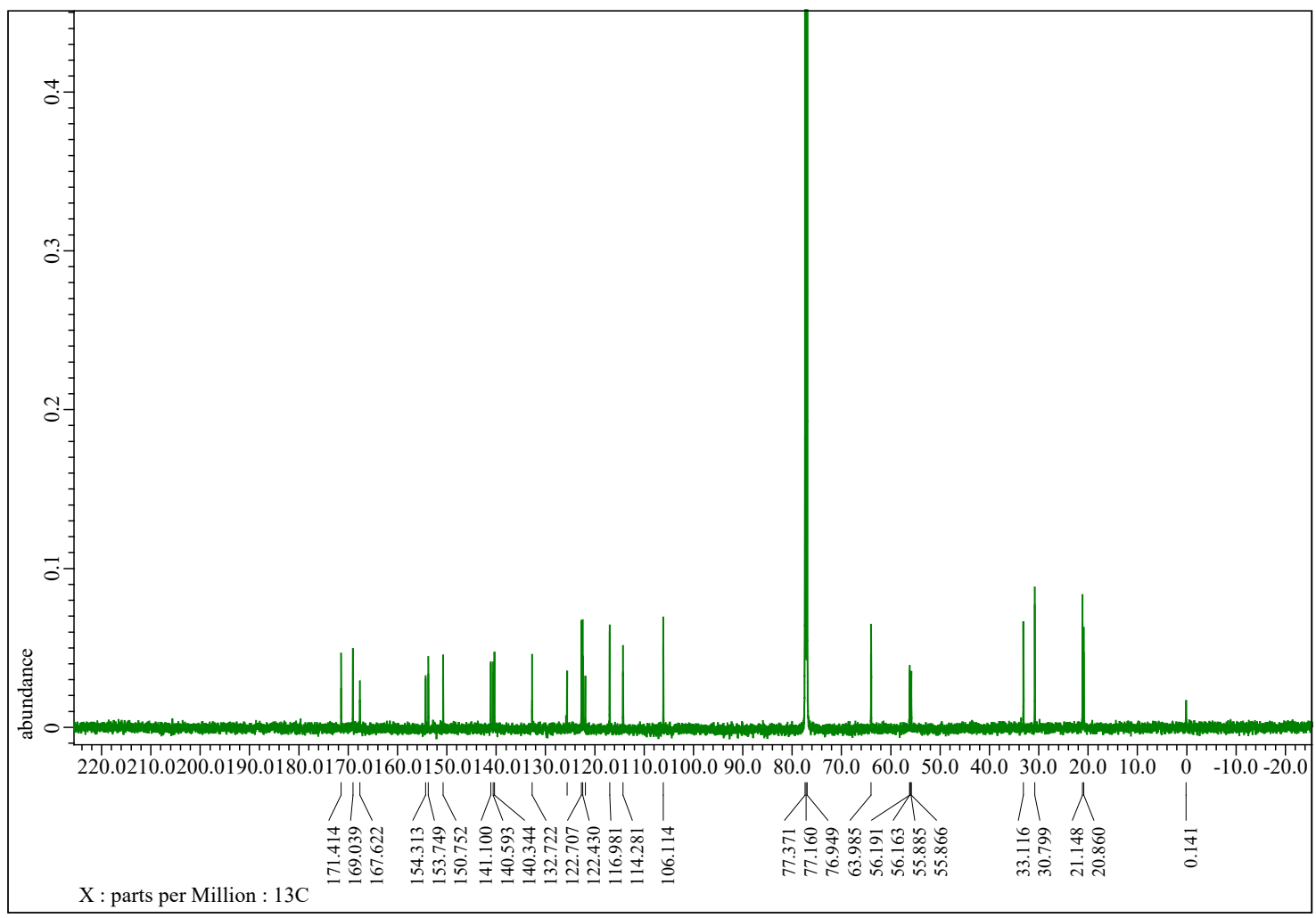


Figure S59. ${ }^{1} \mathrm{H}$ NMR spectrum of compound $38\left(600 \mathrm{MHz}\right.$, in $\left.\mathrm{CDCl}_{3}\right)$

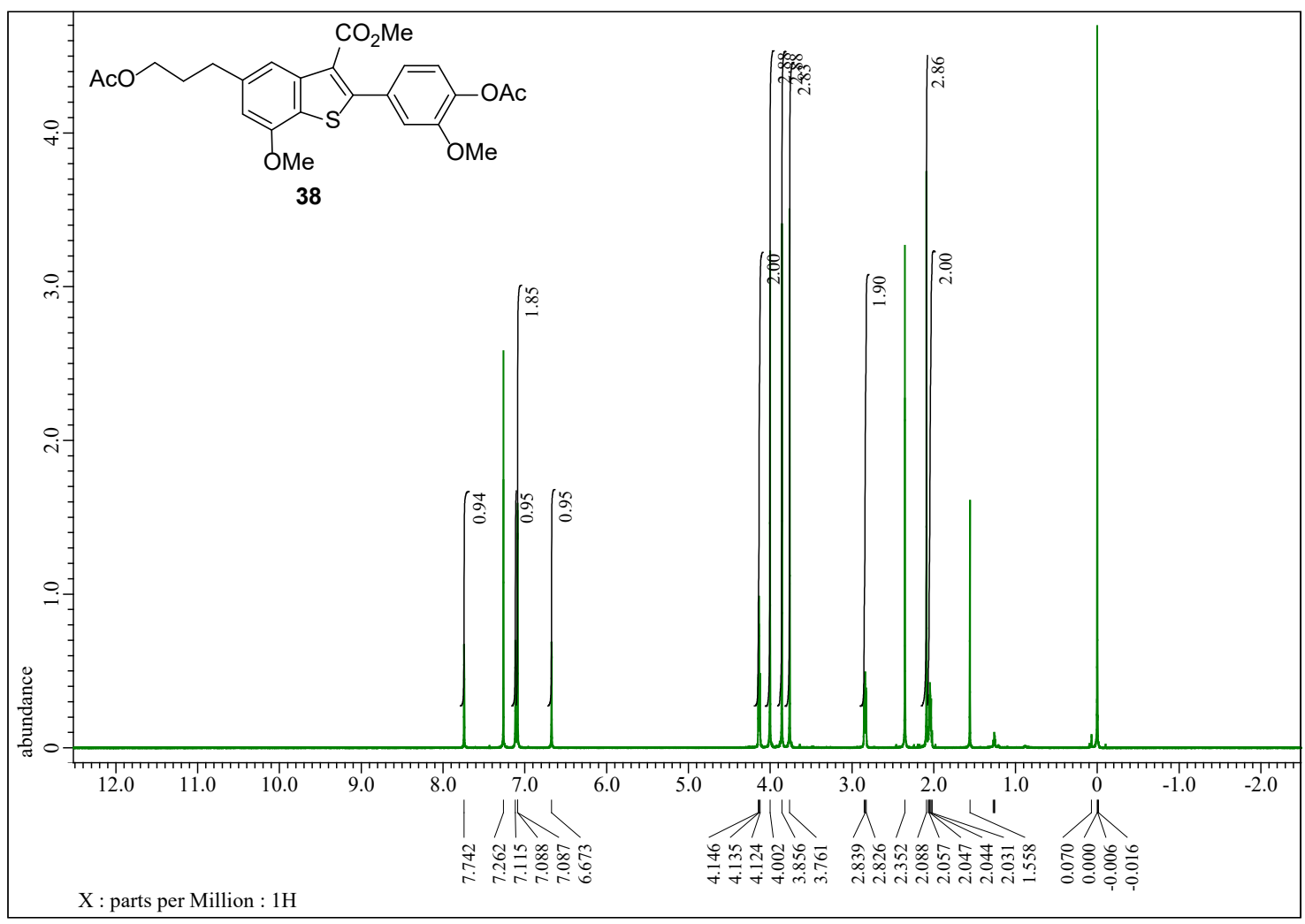

Figure S60. ${ }^{13} \mathrm{C}\left\{{ }^{1} \mathrm{H}\right\}$ NMR spectrum of compound $38\left(150 \mathrm{MHz}\right.$, in $\left.\mathrm{CDCl}_{3}\right)$

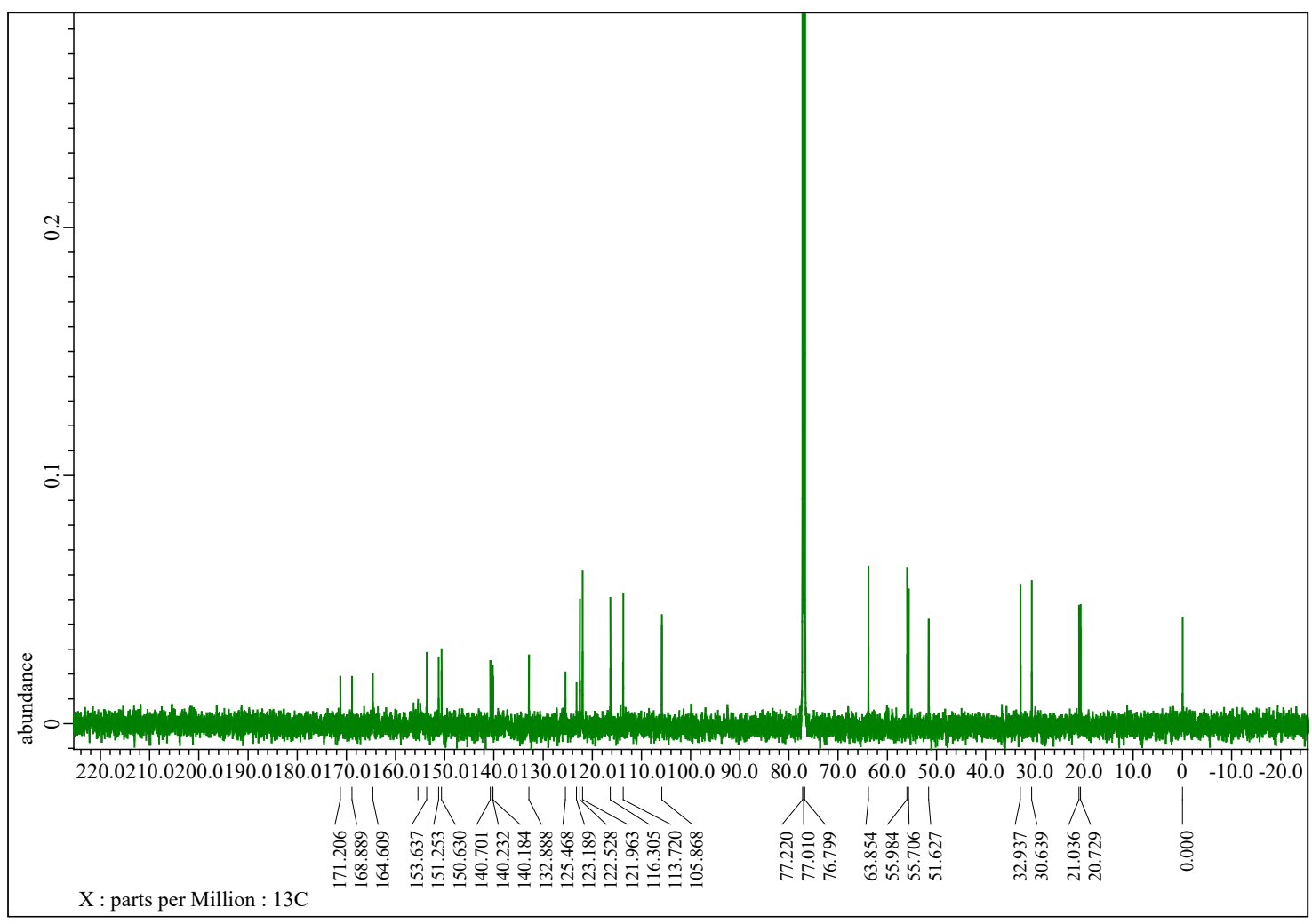


Figure S61. ${ }^{1} \mathrm{H}$ NMR spectrum of compound $39\left(400 \mathrm{MHz}\right.$, in $\left.\mathrm{CDCl}_{3}\right)$

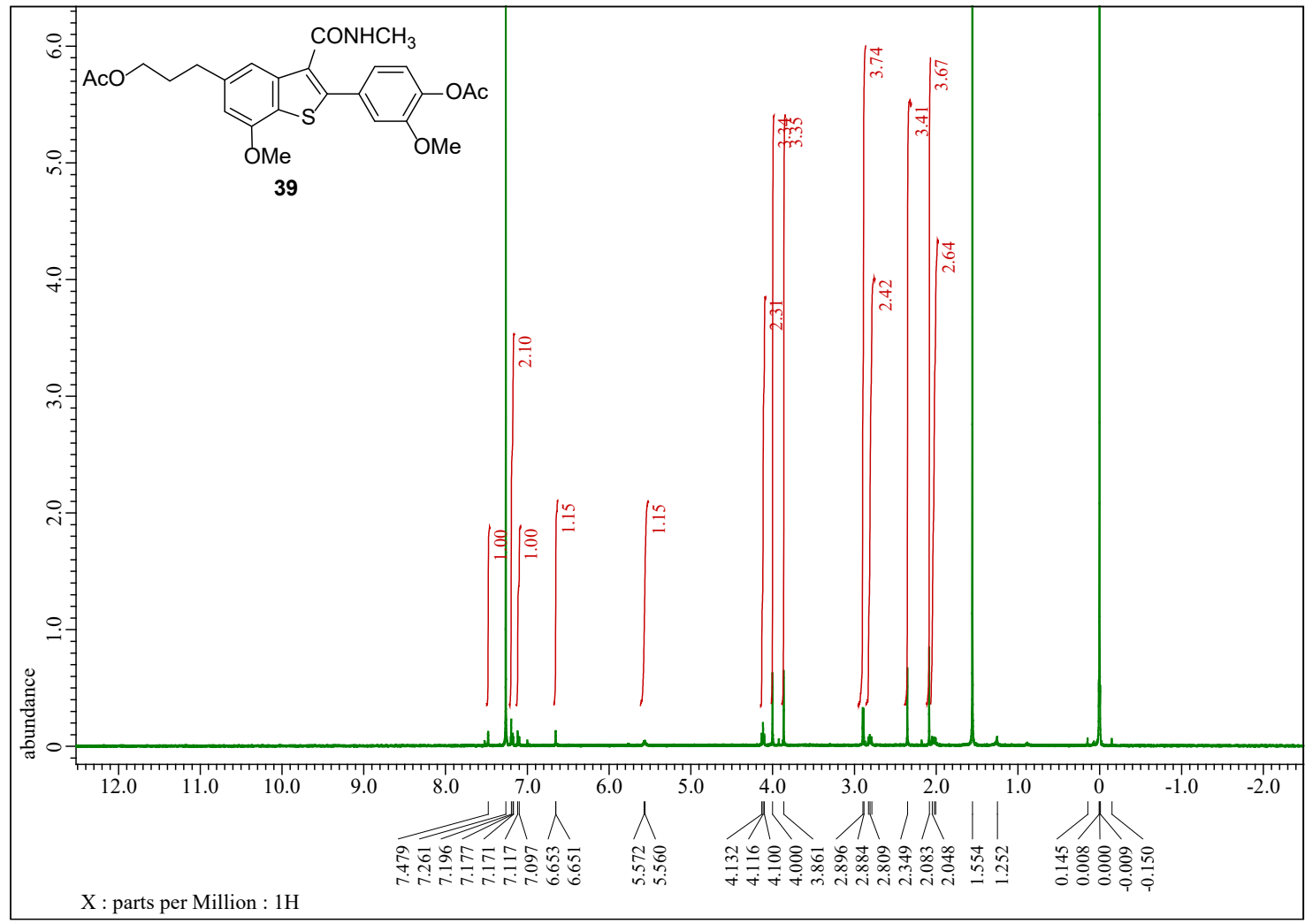

Figure S62. ${ }^{13} \mathrm{C}\left\{{ }^{1} \mathrm{H}\right\}$ NMR spectrum of compound $39\left(150 \mathrm{MHz}\right.$, in $\left.\mathrm{CDCl}_{3}\right)$

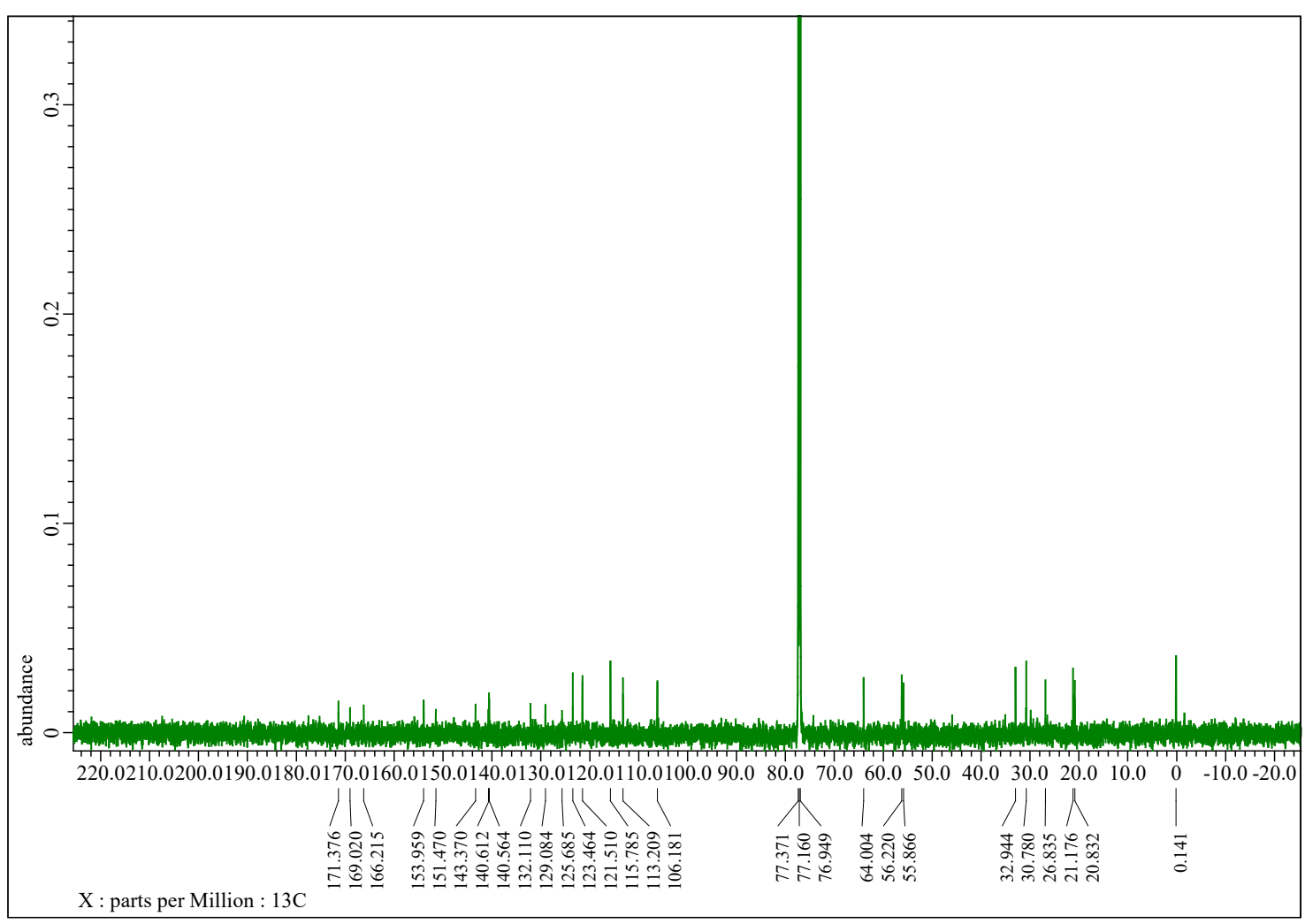


Figure S63. ${ }^{1} \mathrm{H}$ NMR spectrum of compound $40\left(600 \mathrm{MHz}\right.$, in $\left.\mathrm{CDCl}_{3}\right)$

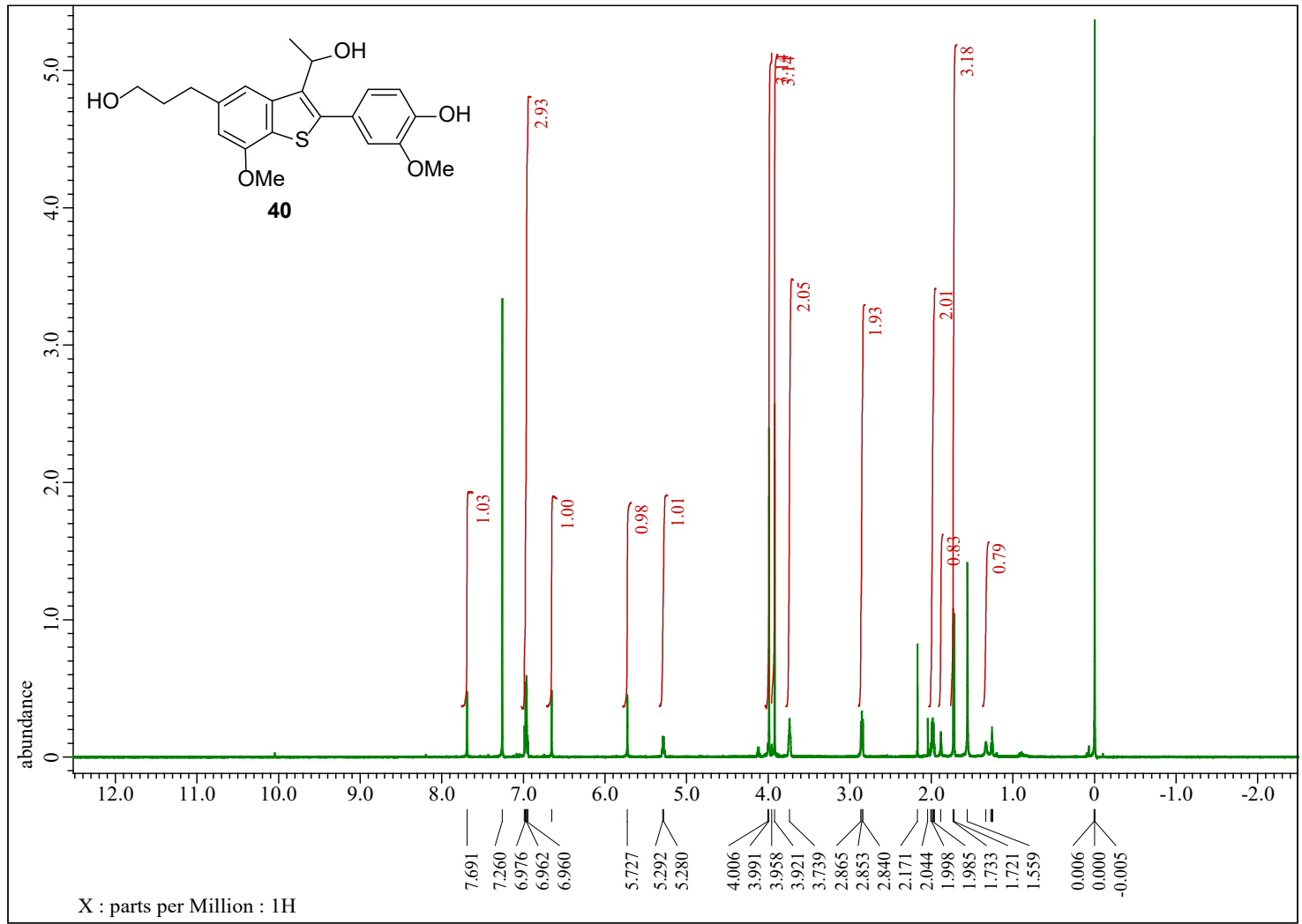

Figure S64. ${ }^{13} \mathrm{C}\left\{{ }^{1} \mathrm{H}\right\}$ NMR spectrum of compound $40\left(100 \mathrm{MHz}\right.$, in $\left.\mathrm{CD}_{3} \mathrm{OD}\right)$

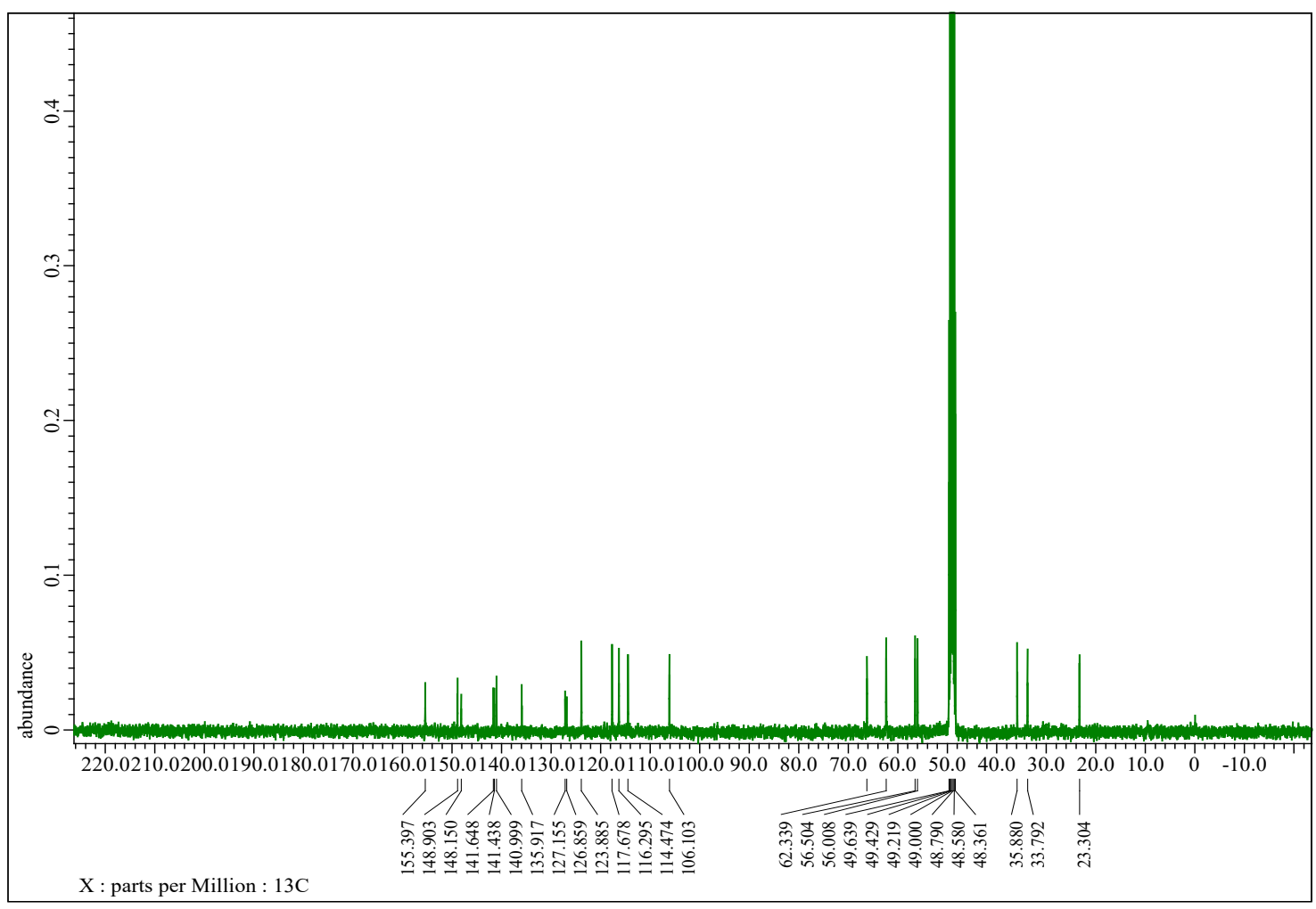


Figure S65. ${ }^{1} \mathrm{H}$ NMR spectrum of compound $41\left(400 \mathrm{MHz}\right.$, in $\left.\mathrm{CDCl}_{3}\right)$

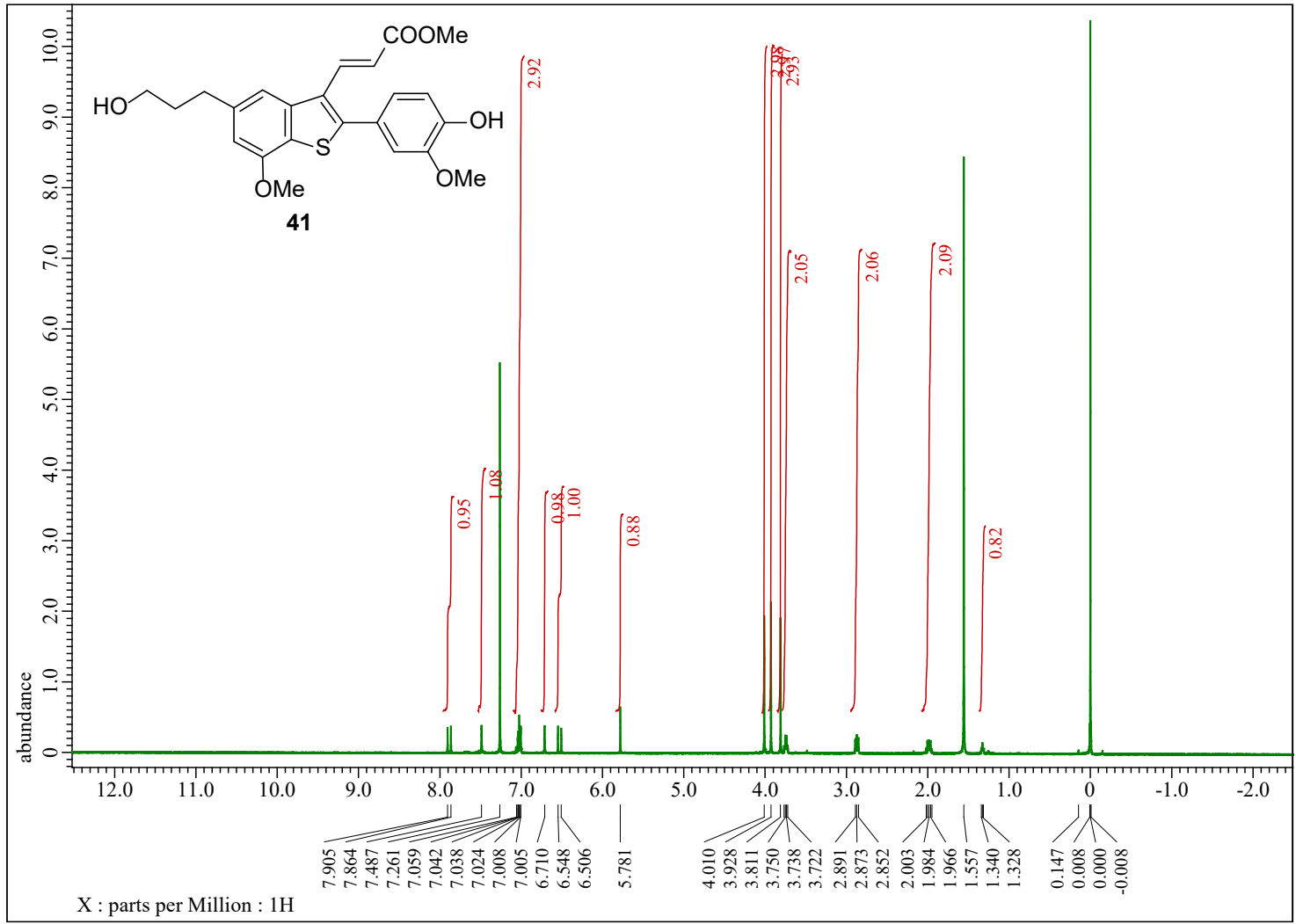

Figure S66. ${ }^{13} \mathrm{C}\left\{{ }^{1} \mathrm{H}\right\}$ NMR spectrum of compound $41\left(150 \mathrm{MHz}\right.$, in $\left.\mathrm{CDCl}_{3}\right)$

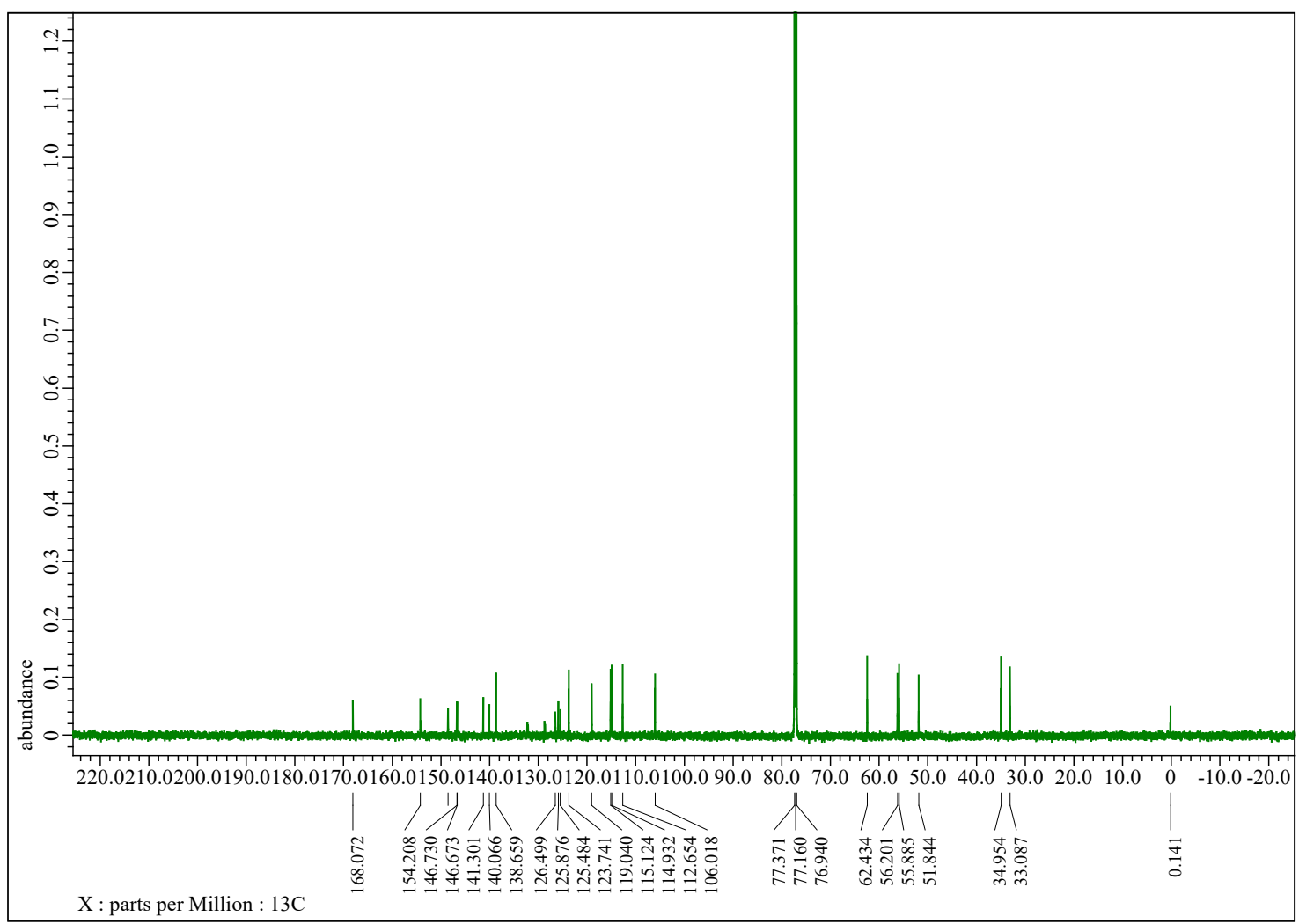


Figure S67. ${ }^{1} \mathrm{H}$ NMR spectrum of compound $42\left(400 \mathrm{MHz}\right.$, in $\left.\mathrm{CDCl}_{3}\right)$

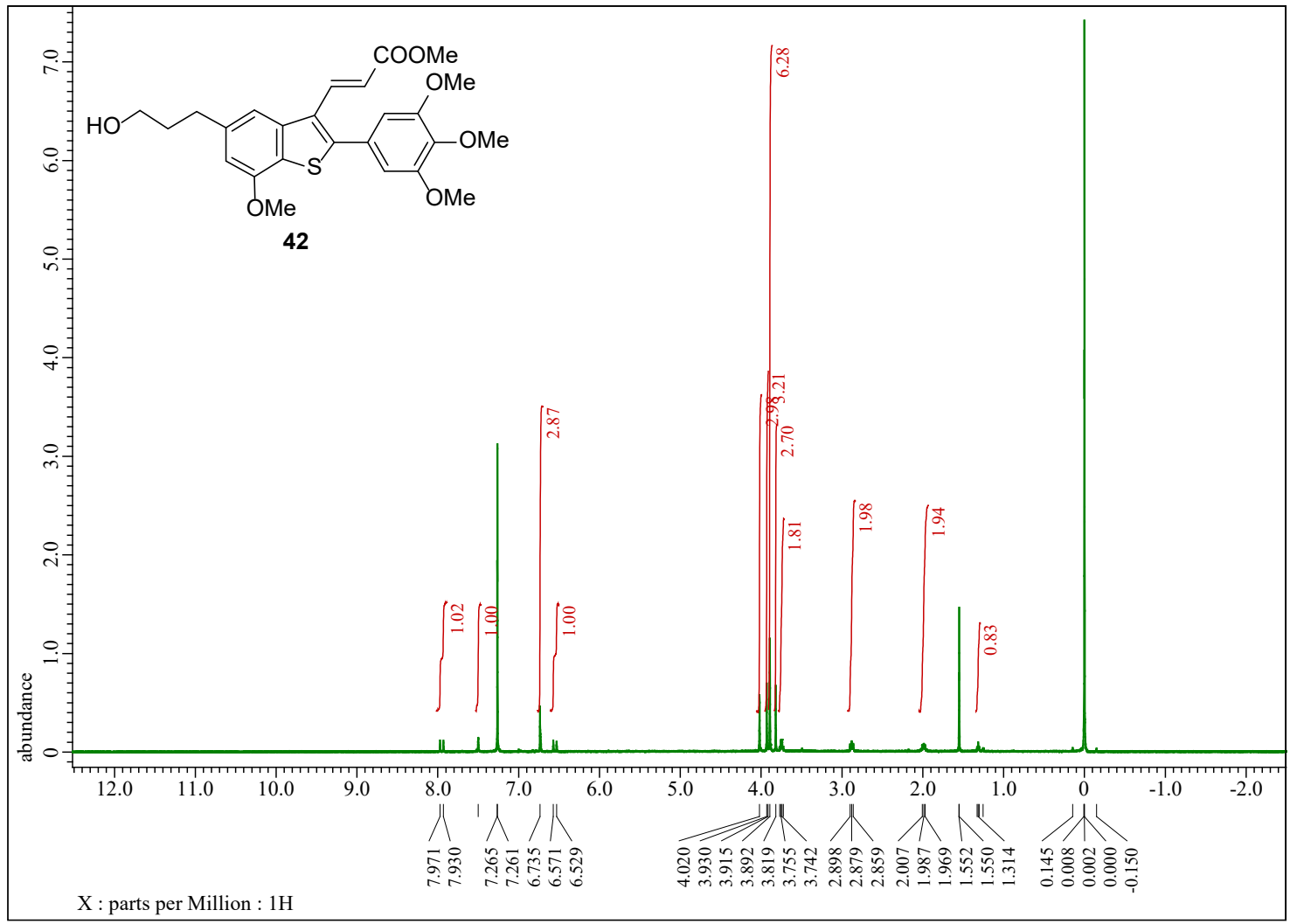

Figure S68. ${ }^{13} \mathrm{C}\left\{{ }^{1} \mathrm{H}\right\}$ NMR spectrum of compound $42\left(150 \mathrm{MHz}\right.$, in $\left.\mathrm{CDCl}_{3}\right)$

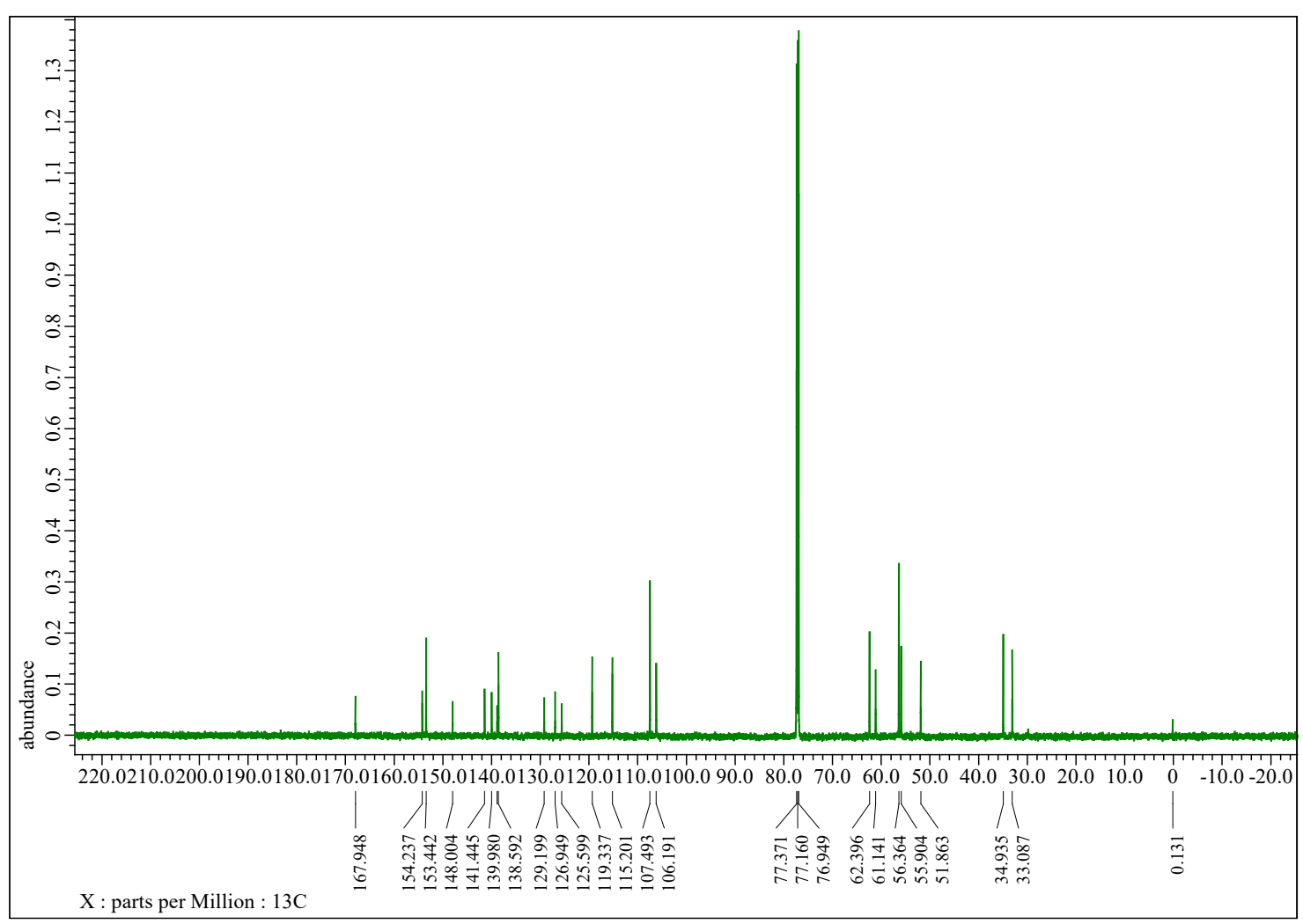


Figure S69. ${ }^{1} \mathrm{H}$ NMR spectrum of compound $43\left(400 \mathrm{MHz}\right.$, in $\left.\mathrm{CDCl}_{3}\right)$

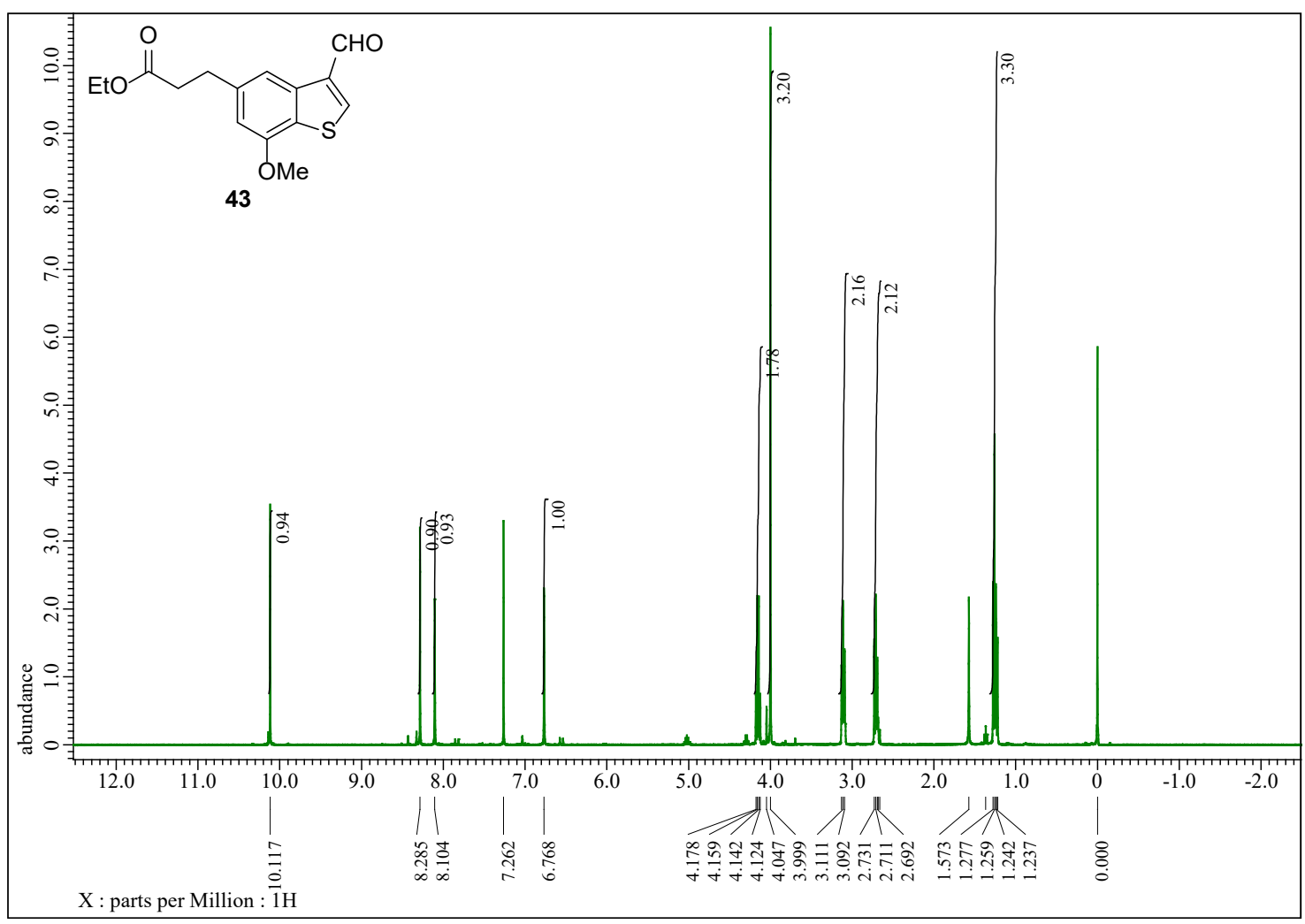

Figure S70. ${ }^{13} \mathrm{C}\left\{{ }^{1} \mathrm{H}\right\}$ NMR spectrum of compound $43\left(150 \mathrm{MHz}\right.$, in $\left.\mathrm{CDCl}_{3}\right)$

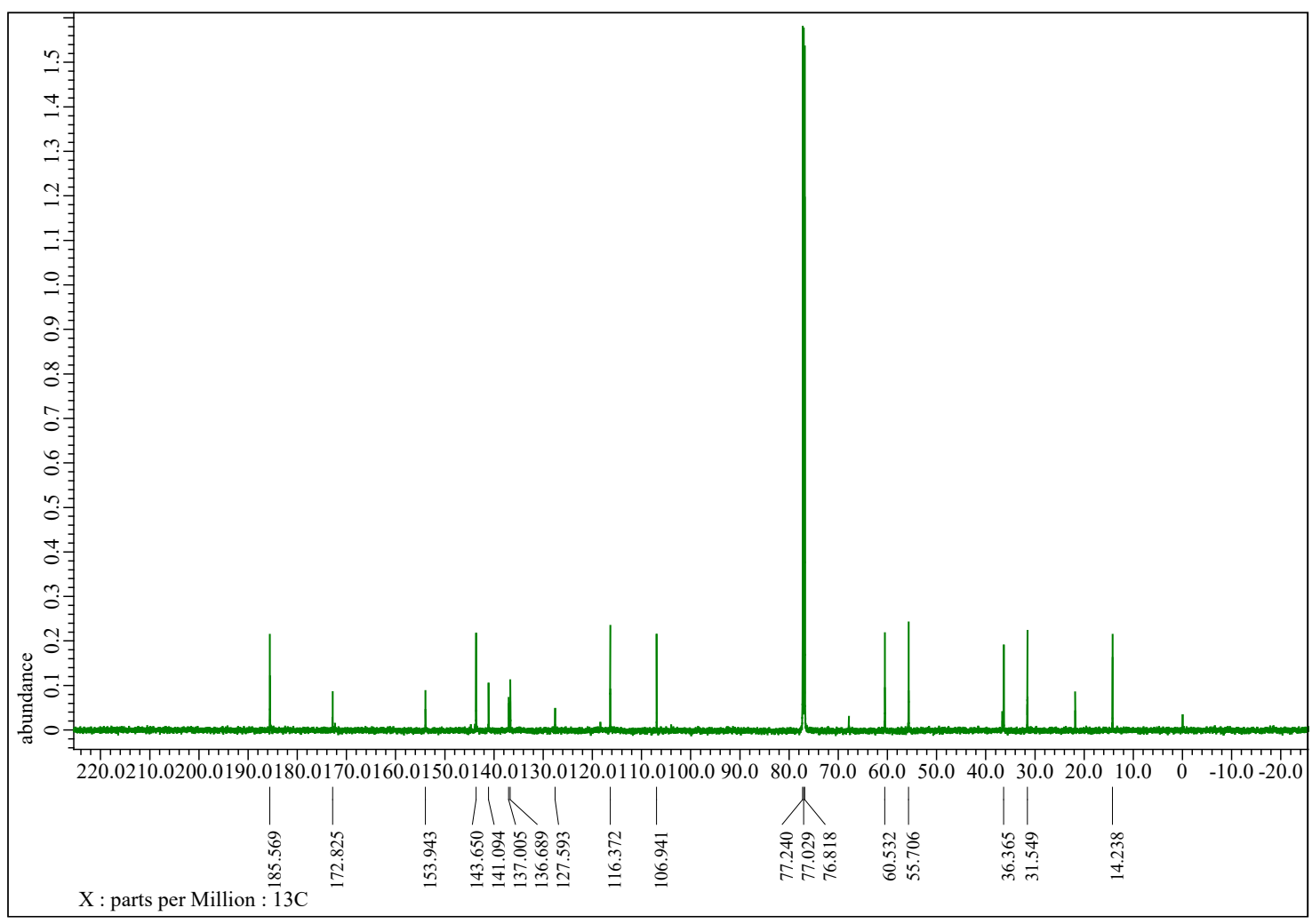


Figure S71. ${ }^{1} \mathrm{H}$ NMR spectrum of compound $44\left(600 \mathrm{MHz}\right.$, in $\left.\mathrm{CDCl}_{3}\right)$

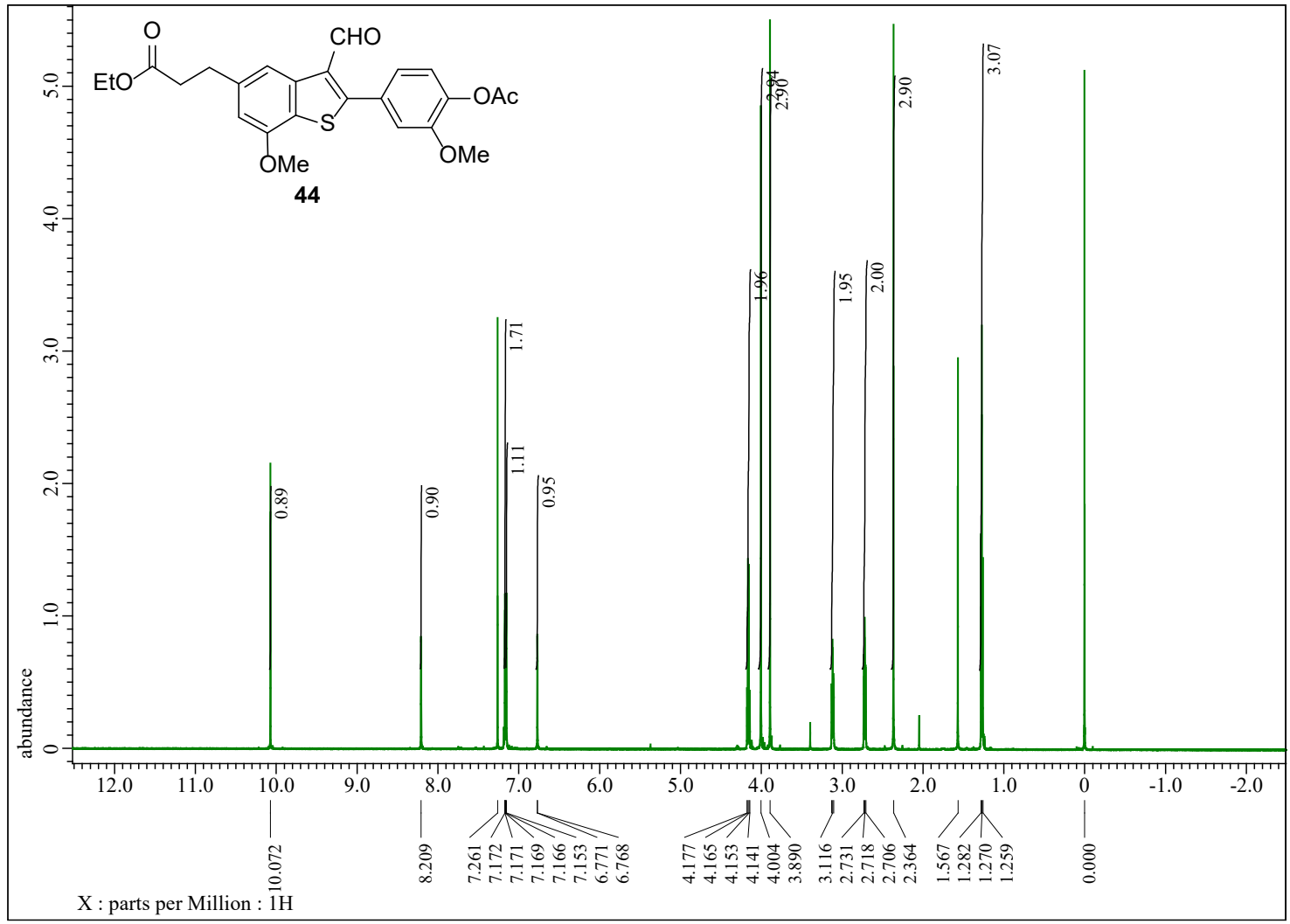

Figure S72. ${ }^{13} \mathrm{C}\left\{{ }^{1} \mathrm{H}\right\}$ NMR spectrum of compound $44\left(100 \mathrm{MHz}\right.$, in $\left.\mathrm{CDCl}_{3}\right)$

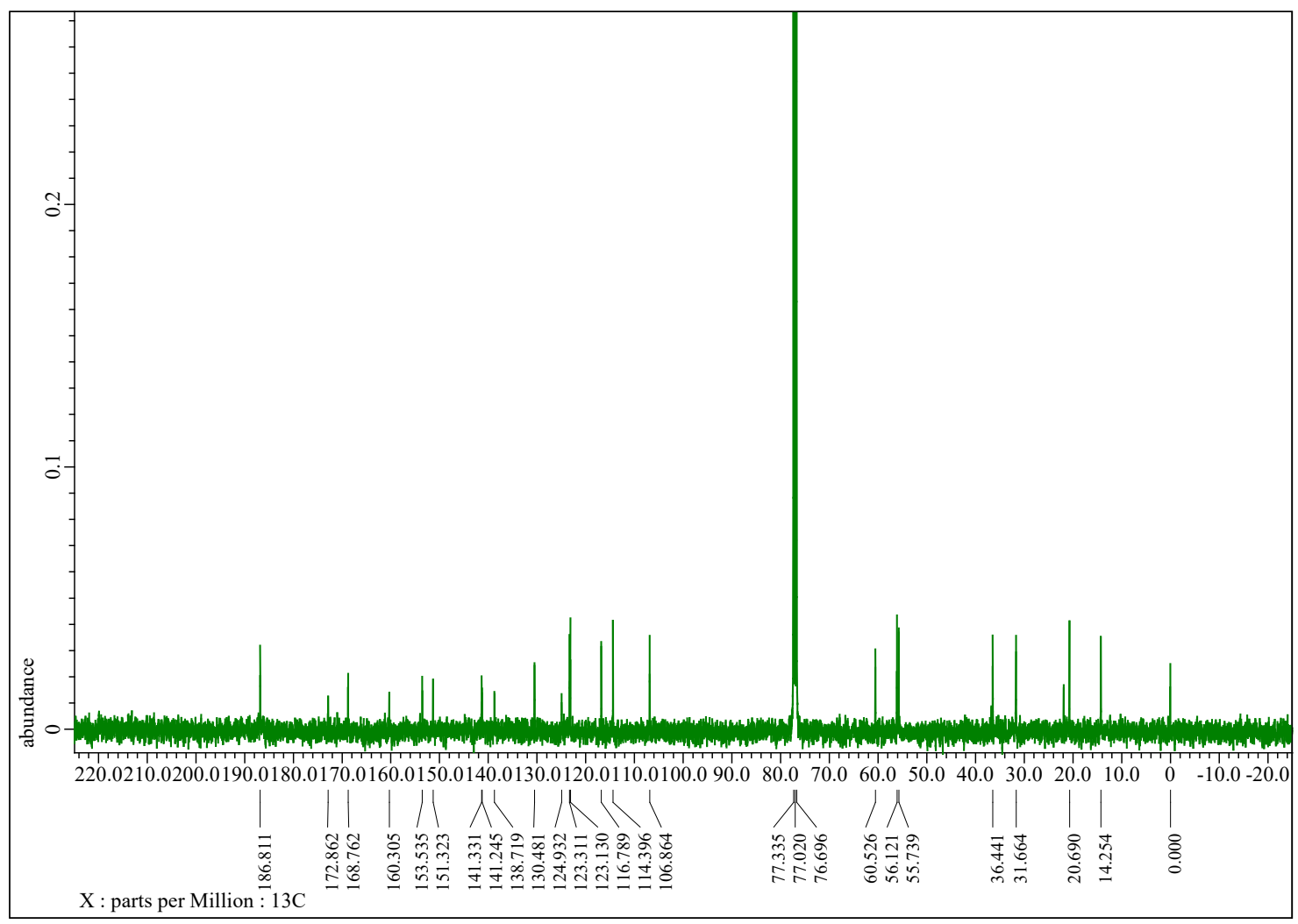


Figure S73. ${ }^{1} \mathrm{H}$ NMR spectrum of compound $45\left(400 \mathrm{MHz}\right.$, in $\left.\mathrm{CDCl}_{3}\right)$

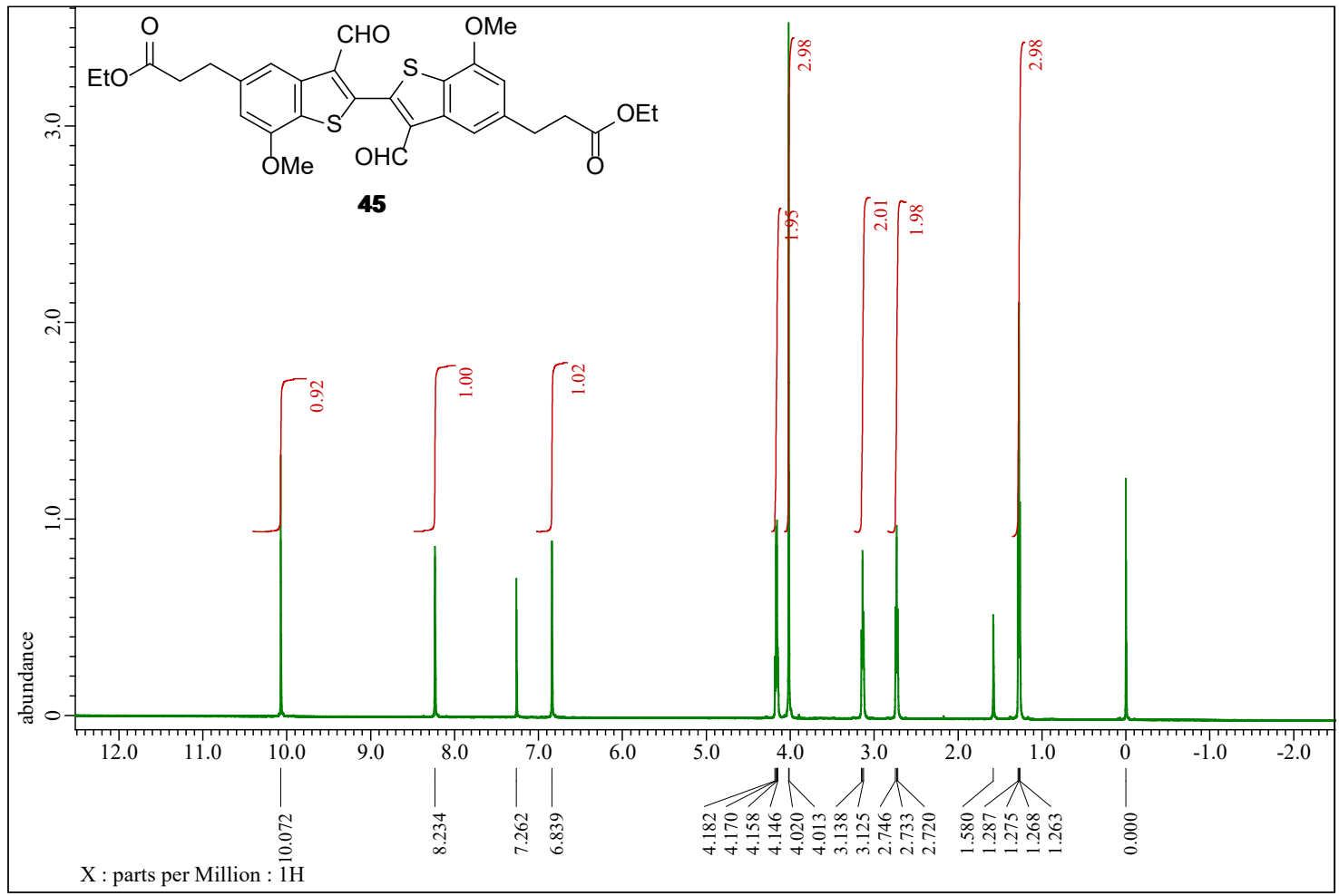

Figure S74. ${ }^{13} \mathrm{C}\left\{{ }^{1} \mathrm{H}\right\}$ NMR spectrum of compound $45\left(150 \mathrm{MHz}\right.$, in $\left.\mathrm{CDCl}_{3}\right)$

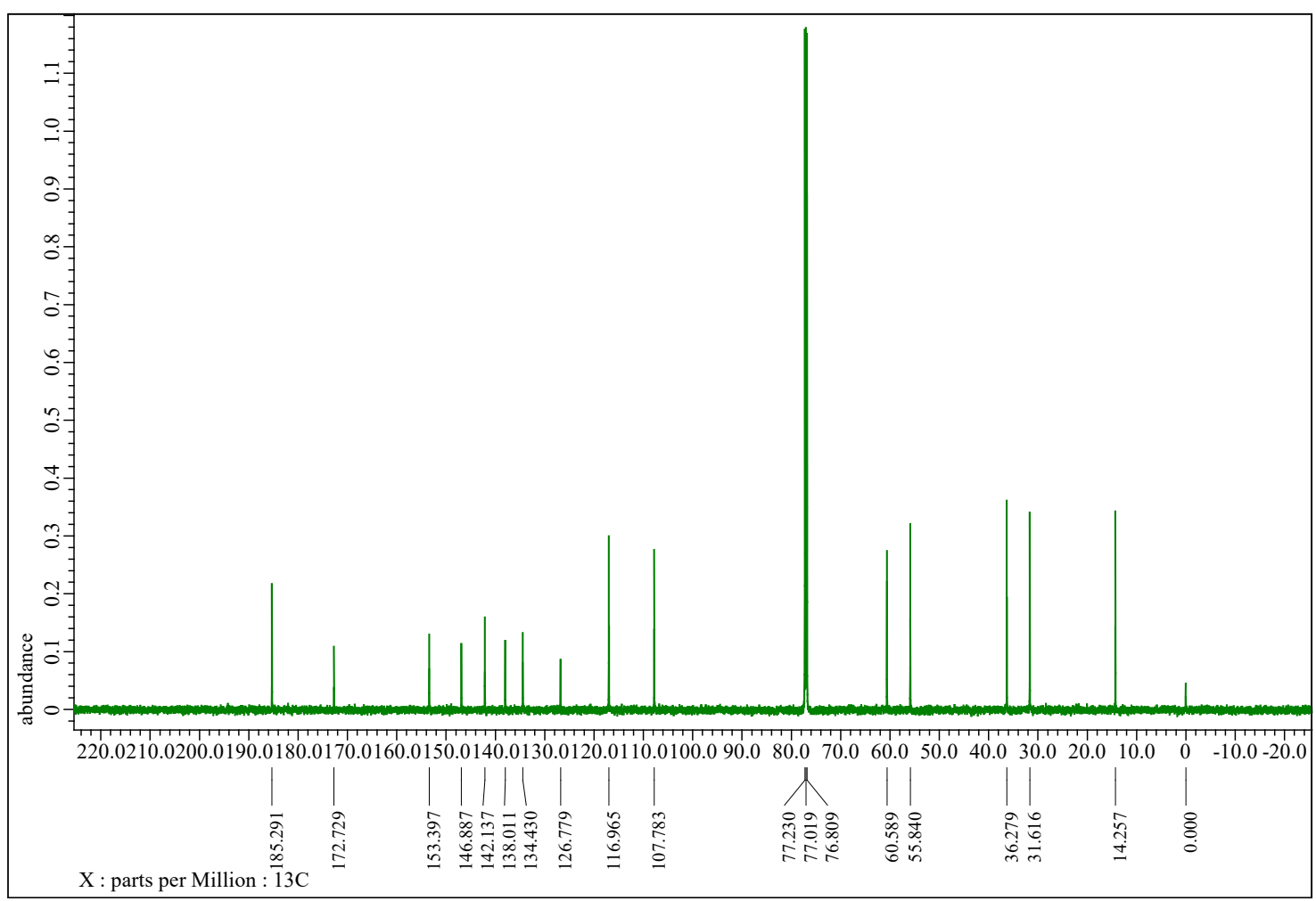


Figure S75. ${ }^{1} \mathrm{H}$ NMR spectrum of compound $\mathbf{5 2}\left(600 \mathrm{MHz}\right.$, in $\left.\mathrm{CDCl}_{3}\right)$

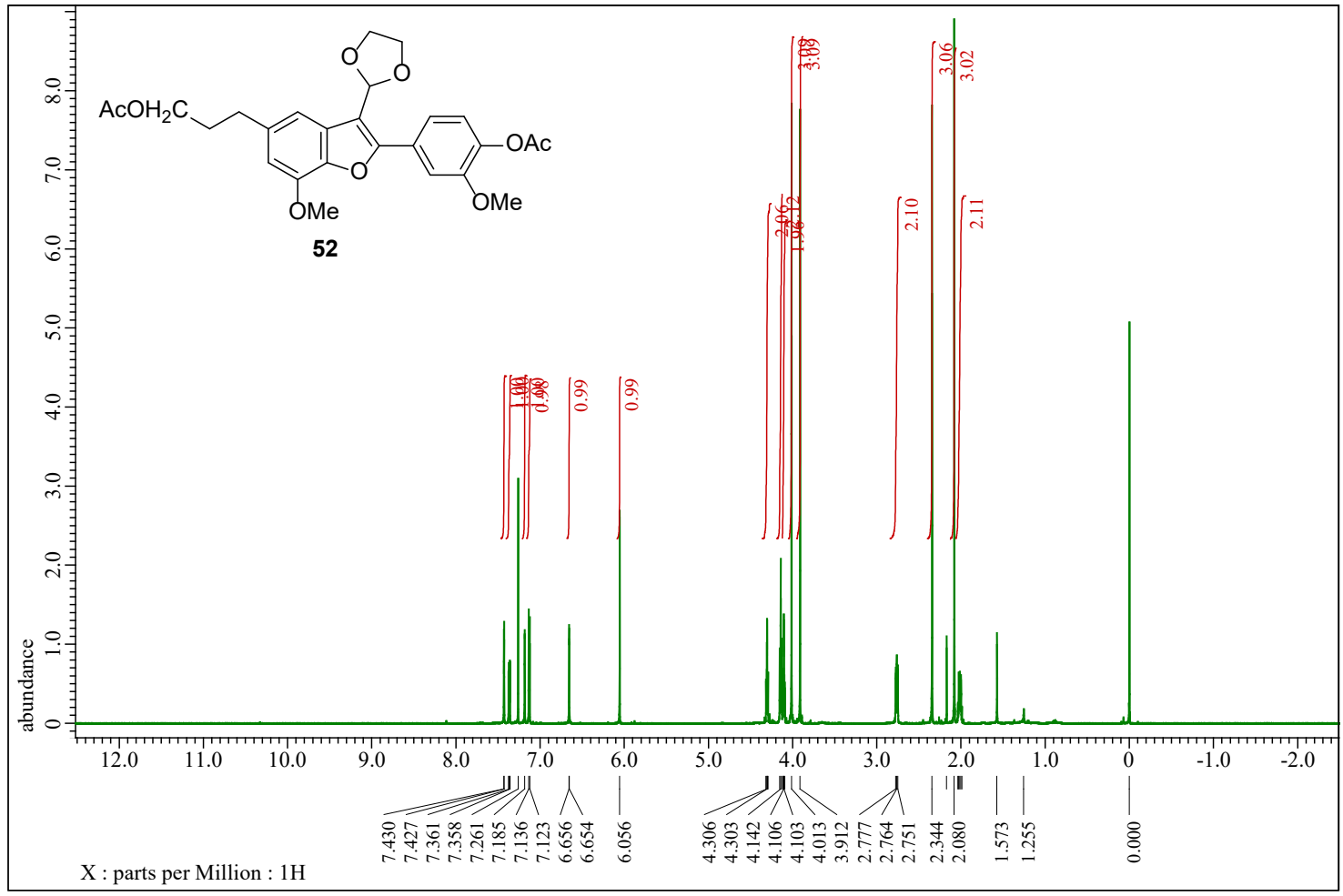

Figure S76. ${ }^{13} \mathrm{C}\left\{{ }^{1} \mathrm{H}\right\}$ NMR spectrum of compound $52\left(150 \mathrm{MHz}\right.$, in $\left.\mathrm{CDCl}_{3}\right)$

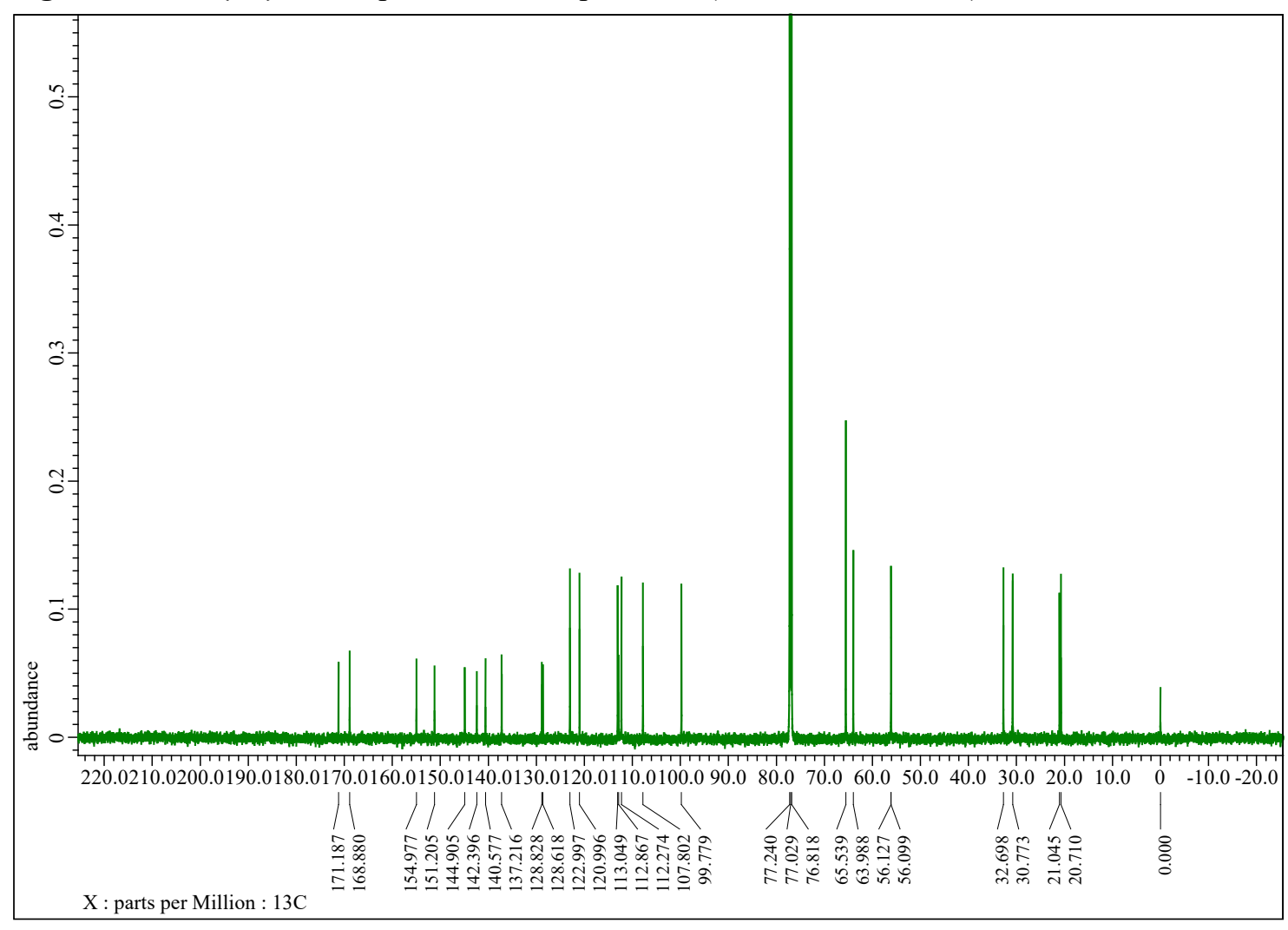

